UNIVERSIDADE DE SÃO PAULO

INSTITUTO DE GEOCIÊNCIAS

\title{
MUDANÇAS CLIMÁTICAS E ANTRÓPICAS NO LESTE DA AMAZÔNIA DURANTE O HOLOCENO TARDIO
}

Dailson José Bertassoli Junior

Orientador: Prof. Dr. André Oliveira Sawakuchi

TESE DE DOUTORAMENTO

Programa de Pós-Graduação em Geoquímica e Geotectônica

São Paulo

2019 

UNIVERSIDADE DE SÃO PAULO

INSTITUTO DE GEOCIÊNCIAS

\title{
MUDANÇAS CLIMÁTICAS E ANTRÓPICAS NO LESTE DA AMAZÔNIA DURANTE O HOLOCENO TARDIO
}

\author{
Dailson José Bertassoli Junior
}

Tese apresentada ao Instituto de Geociências da Universidade de São Paulo para obtenção do título de Doutor em Ciências

Área de concentração: Geoquímica e Geotectônica

Orientador: Prof. Dr. André Oliveira Sawakuchi

São Paulo

2019 
Autorizo a reprodução e divulgação total ou parcial deste trabalho, por qualquer meio convencional ou eletrônico, para fins de estudo e pesquisa, desde que citada a fonte.

Serviço de Biblioteca e Documentação do IGc/USP

Ficha catalográfica gerada automaticamente com dados fornecidos pelo(a) autor(a) via programa desenvolvido pela Seção Técnica de Informática do ICMC/USP

Bibliotecários responsáveis pela estrutura de catalogação da publicação: Sonia Regina Yole Guerra - CRB-8/4208 | Anderson de Santana - CRB-8/6658

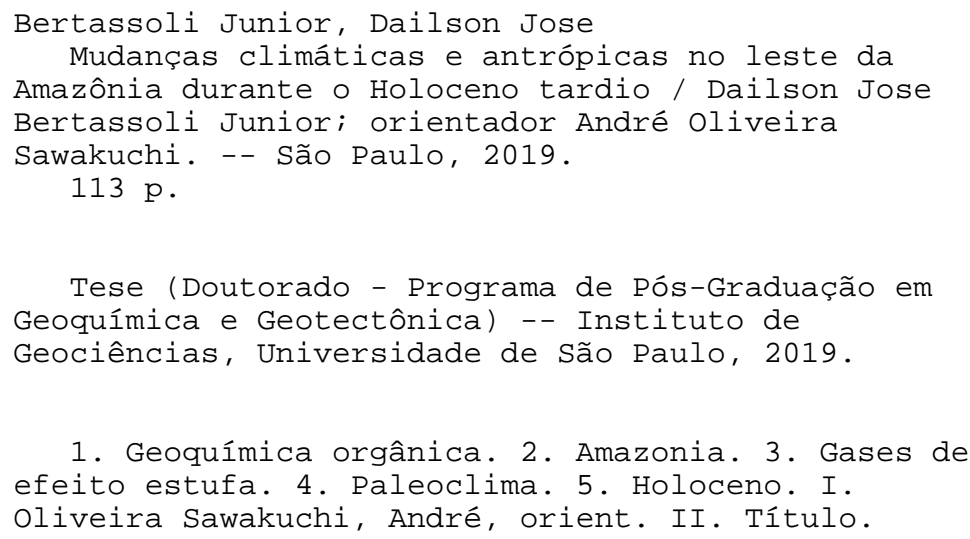




\section{UNIVERSIDADE DE SÃO PAULO \\ INSTITUTO DE GEOCIÊNCIAS}

\section{MUDANÇAS CLIMÁTICAS E ANTRÓPICAS NO LESTE DA AMAZÔNIA DURANTE O HOLOCENO TARDIO}

\section{DAILSON JOSÉ BERTASSOLI JUNIOR}

Orientador: Prof. Dr. André Oliveira Sawakuchi

Tese de Doutorado

№ 607

COMISSÃO JULGADORA

Dr. André Oliveira Sawakuchi

Dr. Paulo César Fonseca Giannini

Dr. Luiz Carlos Ruiz Pessenda

Dra. Ana Luiza Spadano Albuquerque

Dr. Pedro Leite da Silva Dias

Dr. Humberto Marotta Ribeiro

SÃO PAULO

2019 

Aos meus pais, Mirian e Dailson 


\section{AGRADECIMENTOS}

Agradeço primeiramente ao Prof. Dr. André Oliveira Sawakuchi pelas oportunidades, pela paciência e por ser um grande exemplo para mim;

Ao Prof. Dr. Enno Schefuß, por me receber no MARUM e proporcionar uma incrível experiência de estágio no exterior;

Aos diversos colegas e professores que participaram da construção desse trabalho: Cristiano, Fabiano, Gelvam, Kleiton, Victor, Marcelo, Thays, Luciana, Renato, Chico, Liliane, Christoph, Rudney, Thomas, Tatiana, Leandro, Henrique, Mauricio, Michael, Jens, Matthias, Krysna, Samantha, Dani, Ronca, Naldo, Neto, Ilma, Denise, e tantos outros;

Aos amigos do MARUM, do LEGAL, de Moxi e da Turma 51;

Aos funcionários do IGc-USP, CENA-USP, EACH, UFPA e MARUM pelo suporte;

À CAPES pelo breve período em que contribuiu com uma bolsa de doutorado (PPGG-IGc/USP) e à FAPESP, pelo apoio financeiro na forma de uma bolsa de doutorado (2016/11141-2), de uma bolsa estágio de pesquisa no exterior (BEPE, 2017/25735-4) e de um projeto de auxílio à pesquisa (16/02656-9) que financiou parte dos trabalhos.

E em especial à minha família, essencial durante todo o trajeto. 
"If knowledge can create problems, it is not through ignorance that we can solve them."

Isaac Asimov (1920-1992) 


\section{RESUMO}

Mudanças climáticas e antrópicas no leste amazônico podem promover alterações significativas na dinâmica hidrológica e sedimentar de sistemas fluviais e afetar ecossistemas aquáticos e de florestas alagáveis. De tal modo, o presente estudo visou à reconstrução de mudanças na precipitação e vegetação no leste da Amazônia durante o Holoceno tardio para entender a resposta deste sistema às variações climáticas dos últimos milênios. Uma vez que mudanças impostas pela implantação de usinas hidrelétricas tem gerado alterações ambientais abruptas e severas nos rios amazônicos, este estudo também visou aprofundar o conhecimento sobre a dinâmica do carbono no Rio Xingu, um dos maiores rios do leste da Amazônia, afetado recentemente pela implantação da barragem de Belo Monte. Testemunhos sedimentares e amostras de sedimento em suspensão e de fundo foram coletados para a investigação de mudanças ambientais e climáticas a partir de indicadores baseados em análises isotópicas de compostos orgânicos específicos, geoquímica inorgânica e granulometria. Alterações na precipitação, vegetação e aporte sedimentar foram comparadas a eventos climáticos globais e variações no Sistema de Monções da América do Sul levantadas a partir de outros registros climáticos. Para investigar os efeitos climáticos e antrópicos na dinâmica do carbono foram também avaliadas possíveis alterações na retenção de matéria orgânica e na emissão de metano e dióxido de carbono no Rio Xingu. Os resultados obtidos permitiram a identificação de variações na vazão dos rios Amazonas e Xingu associadas a anomalias de temperatura em regiões extratropicais ao longo do Holoceno tardio. Demonstraram também que alterações hidrológicas naturais e antrópicas afetam o balanço de carbono em ambientes aquáticos amazônicos.

Palavras-chave: Geoquímica orgânica; Amazônia; Carbono; Xingu; Metano; Dióxido de Carbono; Belo Monte; Gases de Efeito Estufa; Holoceno; Paleoclima. 


\begin{abstract}
Climatic and anthropogenic changes in Eastern Amazonia may promote significant alterations in hydrologic and sedimentary dynamics of fluvial systems and threaten aquatic and flooding forest ecosystems. As such, this study aimed at the reconstruction of precipitation and vegetation changes in Eastern Amazonia during the late Holocene in order to understand the response of this system to climatic variations of the last millennia. Since changes promoted by the construction of hydropower plants have been generating abrupt and severe environmental transformations in Amazonian rivers, the present study also tried to improve the current knowledge about carbon dynamics in the Xingu River, which is one of the largest rivers in Eastern Amazonia and was recently affected by the Belo Monte dam. Sediment cores and bottom and suspended sediment samples were investigated through isotope analysis of specific organic compounds and inorganic geochemistry. Changes in precipitation, vegetation and sediment influx were compared to global climatic events and variations in the South American Monsoon System obtained from other climatic archives. With the purpose of investigating the climatic and anthropogenic impacts on carbon dynamics, potential shifts in organic matter retention and methane and carbon dioxide emissions in the Xingu River were also evaluated. The obtained results allowed the identification of variations in the water discharge of the Amazon and Xingu rivers associated with temperature anomalies in extratropical regions during the late Holocene. They also demonstrated that natural and anthropogenic alterations affect carbon balances in Amazonian aquatic environments.
\end{abstract}

Keywords: Organic geochemistry; Amazonia; Carbon; Xingu; Methane; Carbon Dioxide; Belo Monte; Greenhouse gases; Holocene; Paleoclimate. 


\section{SUMÁRIO}

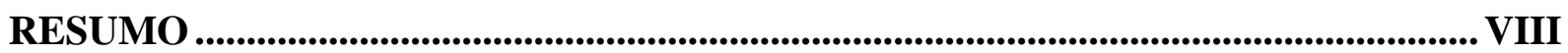

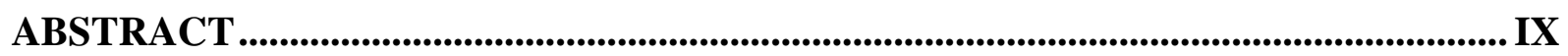

APRESENTAÇÃO.................................................................................................... XIII

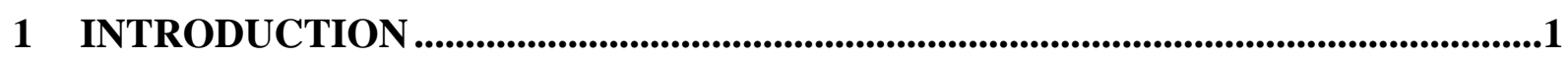

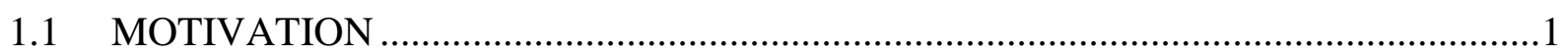

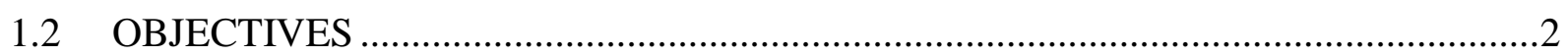

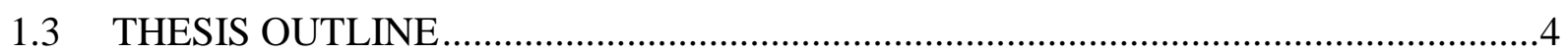

2 SPATIOTEMPORAL VARIATIONS OF RIVERINE DISCHARGE WITHIN THE AMAZON BASIN DURING THE LATE HOLOCENE COINCIDE WITH EXTRATROPICAL TEMPERATURE ANOMALIES ..................................................5

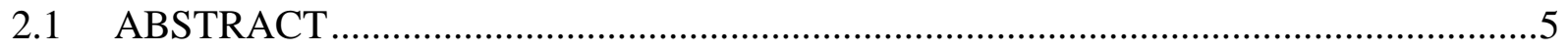

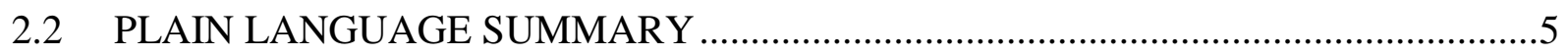

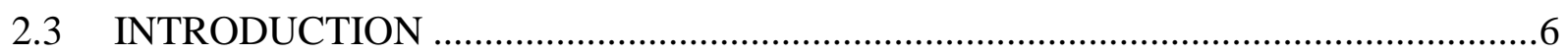

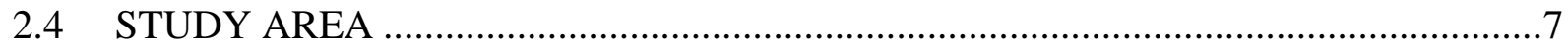

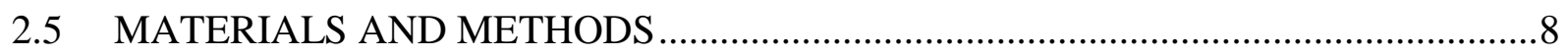

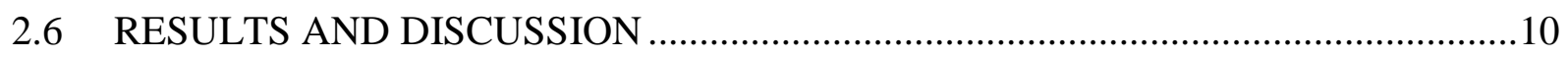

2.6.1 Age models ................................................................................................... 10

2.6.1.1 Amazon lowlands precipitation during the late Holocene .......................................11

2.6.2 Multi-centennial anomalies on the discharge of the Amazon and Xingu rivers …......13

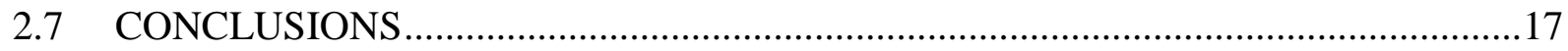

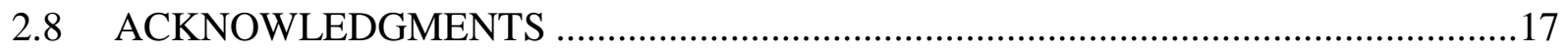

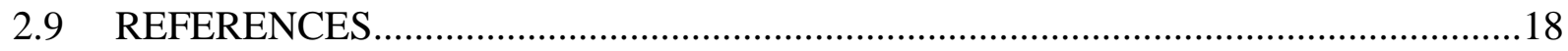

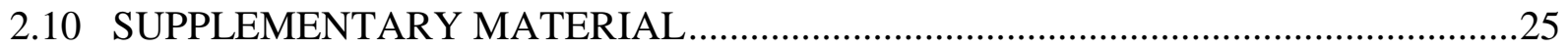

3 THE FATE OF CARBON IN SEDIMENTS OF THE XINGU AND TAPAJÓS CLEARWATER RIVERS, EASTERN AMAZON......................................................26

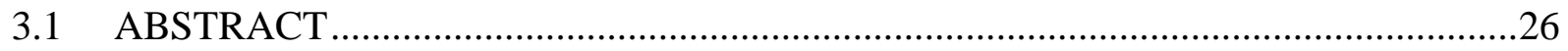

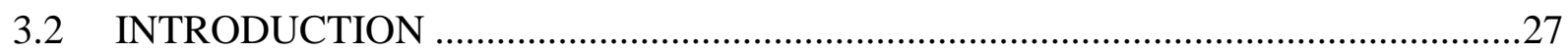

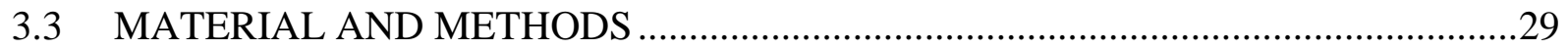

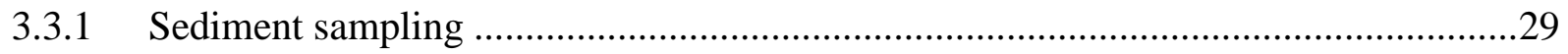

3.3.2 Organic and inorganic geochemistry of sediments...................................................31

3.3.3 Magnetic susceptibility .....................................................................................

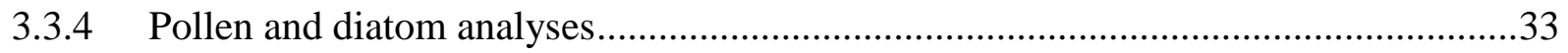

3.3.5 $\quad \mathrm{CH}_{4}$ and $\mathrm{CO}_{2}$ in sediment pore waters...............................................................34 
3.3.6 Optically stimulated luminescence and radiocarbon datings ................................... 34

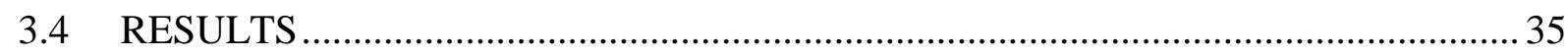

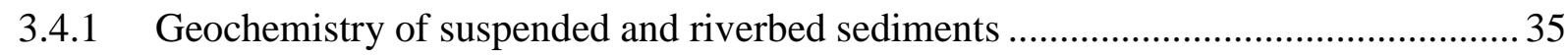

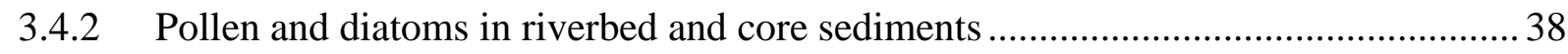

3.4.3 Chronology, magnetic and geochemistry data of sediment cores ............................. 39

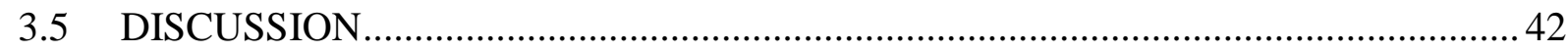

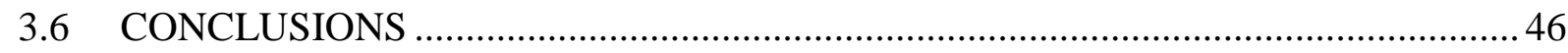

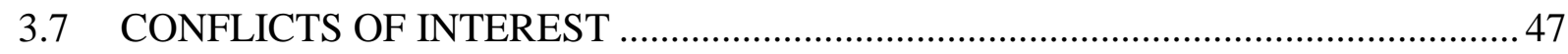

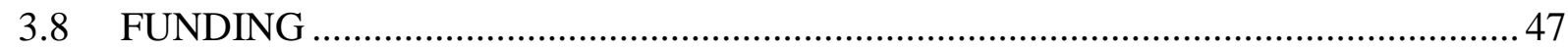

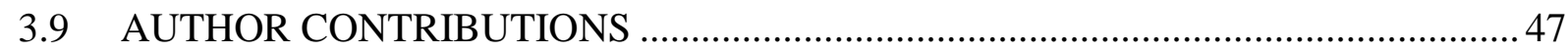

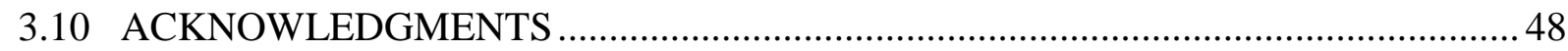

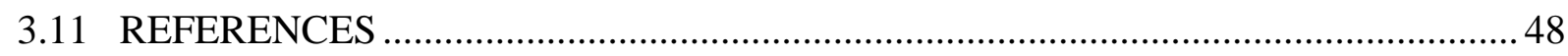

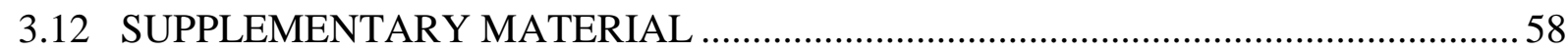

4 PRE- AND POST-FLOODING EMISSIONS OF METHANE AND CARBON DIOXIDE FROM THE BELO MONTE RESERVOIR AREA (XINGU RIVER,

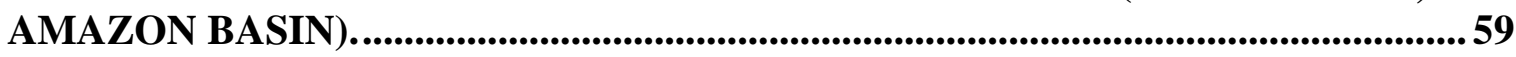

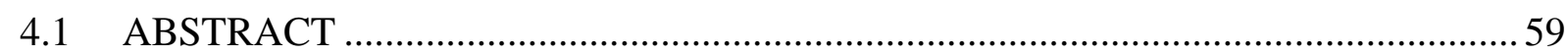

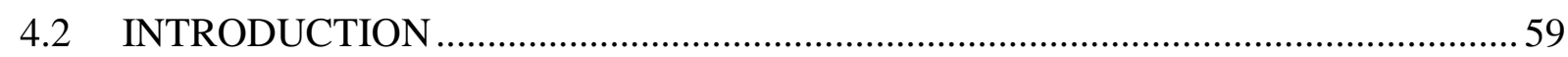

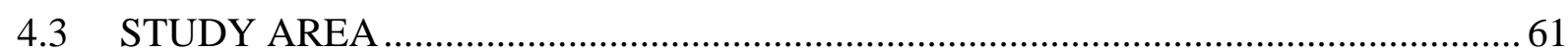

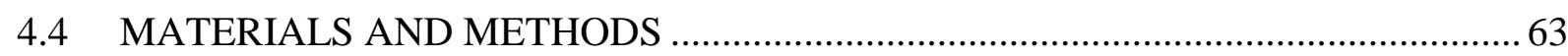

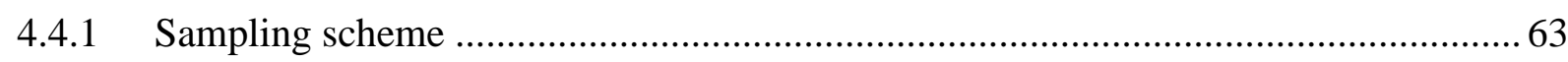

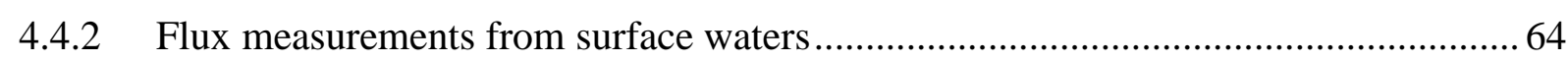

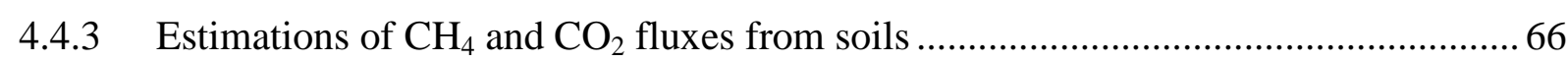

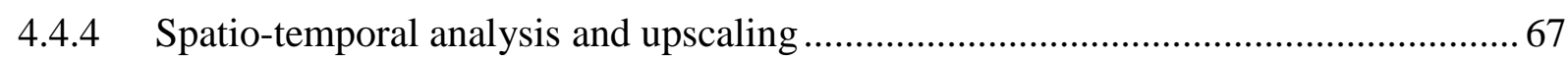

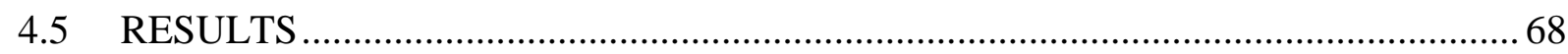

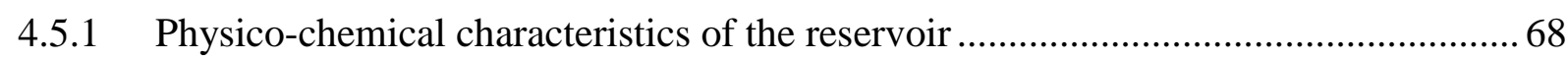

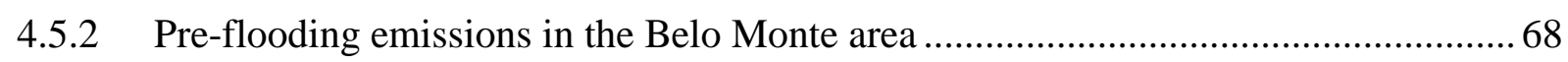

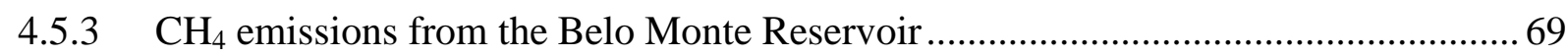

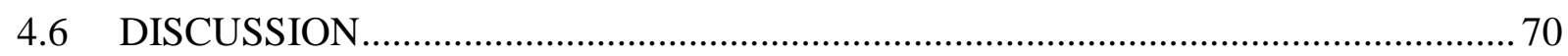

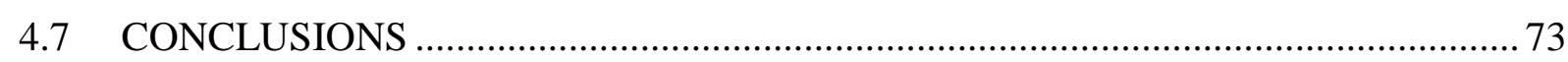

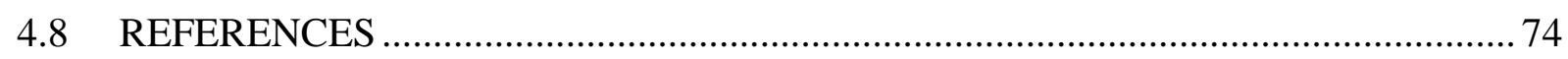

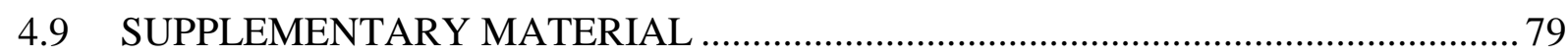

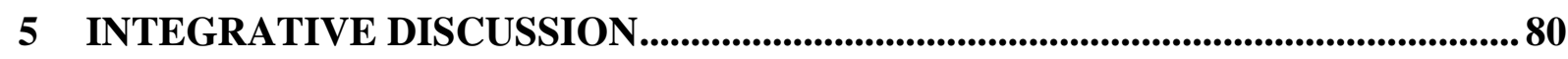

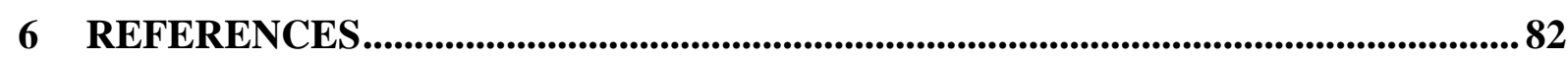

APPENDIX I - SUPPLEMENTARY MATERIAL: SPATIOTEMPORAL VARIATIONS OF RIVERINE DISCHARGE WITHIN THE AMAZON BASIN DURING THE 
LATE HOLOCENE COINCIDE WITH EXTRATROPICAL TEMPERATURE ANOMALIES .

APPENDIX II - SUPPLEMENTARY MATERIAL: THE FATE OF CARBON IN SEDIMENTS OF THE XINGU AND TAPAJÓS CLEARWATER RIVERS, EASTERN AMAZON .099

APPENDIX III - SUPPLEMENTARY MATERIAL: PRE- AND POST-FLOODING EMISSIONS OF METHANE AND CARBON DIOXIDE FROM THE BELO MONTE RESERVOIR AREA (XINGU RIVER, AMAZONIA) 108 


\begin{abstract}
APRESENTAÇÃO
Os resultados desta tese de doutoramento são apresentados na forma de coletânea de artigos. Os trabalhos compõem capítulos e incluem as descrições das áreas de estudo e os métodos aplicados. Cada capítulo é individualmente compreensível e se correlaciona com os outros através de citações. De maneira geral, os trabalhos contemplam os impactos de alterações climáticas e antrópicas na vazão, sedimentação e no balanço de carbono de ambientes aquáticos do leste amazônico. São apresentados dois trabalhos publicados/aceitos para publicação em periódicos internacionais revisados por pares e um que ainda não foi submetido, sendo eles:
\end{abstract}

(1) "Variations on the relative discharge of the Amazon and Xingu rivers during the late Holocene coincide with extratropical temperature anomalies", aceito para publicação no periódico Geophysical Research Letters em Julho de 2019;

(2) "The Fate of Carbon in Sediments of the Xingu and Tapajós Clearwater Rivers, Eastern Amazon", publicado no periódico Frontiers in Marine Science em Fevereiro de 2017; e

(3) "Pre- and post-flooding emissions of methane and carbon dioxide from the Belo Monte reservoir area (Xingu River, Amazonia)"; ainda não submetido.

Uma vez que os trabalhos que constituem o corpo principal da tese foram redigidos em inglês, optou-se pela manutenção da mesma língua nos capítulos de apoio. Além dos artigos, são apresentados a motivação, os objetivos, um condensado com as diretrizes de cada capítulo e uma discussão integrativa. 



\section{INTRODUCTION}

\subsection{Motivation}

The recent advancement of intense anthropogenic activity in Amazonia presents new challenges for the sustainable use of the local water and forest resources. Notably, impacts related to climate change and forest loss may cause the collapse of the Amazon forest in the southern and eastern parts of Amazonia (Davidson et al., 2012; Zemp et al., 2017). Over the last few decades, rates of warming in this region reached $0.25{ }^{\circ} \mathrm{C}$ per decade and forest cover has declined to about $80 \%$ of its original area (Nobre et al. 2016; Malhi et al., 2004). Simultaneously, Amazonia has faced a significant intensification of its hydrological cycle and increased the frequency of extreme climatic events (Gloor et al., 2013; Marengo \& Espinoza, 2015).

Hydrological extremes in Amazonia promote notorious damage to local ecosystems and affect transportation routes, farming, and increase the risks of fires and inundations (Marengo and Espinoza, 2015). Although basin-wide trends in Amazonia precipitation have not yet been clearly established (Marengo \& Espinoza, 2015; Nobre et al. 2016), the synergy between multiple anthropogenic impacts could lead to irreversible changes (Davidson et al. 2012). Climate projections of General Circulation Models (GCMs) from Coupled Model Intercomparison Project 5 (CMIP5) point to spatially heterogeneous changes in Amazonia precipitation, with drier conditions in Eastern Amazonia and wetter conditions in the western part (Duffy et al. 2015). Analyses that couple hydroclimate and ecology variations, on the other hand, highlight the vulnerability of Eastern Amazonia and suggest that deforestation already increased river discharges (about 25\%) of the Araguaia and Tocantins Rivers (Costa et al., 2003; Coe et al. 2011; Davidson et al., 2012 ). Regional Climate Models show that deforestation alone could be responsible for a regional temperature increase of about $0.5{ }^{\circ} \mathrm{C}$ and a rainfall decrease in Amazonia of about $0.2 \mathrm{~mm} /$ day until the end of this century (Lejeune et al. 2011). Also, changes in environmental conditions linked to land-cover changes are spatially dependent, and the consequent precipitation trends likely present a nonlinear response (Lejeune et al. 2011).

Projections of future scenarios and analysis of meteorological data are essential to managing risks associated with anthropogenic drivers of change. The outputs of such models are, however, limited by scarce continuous and long-term rainfall records in Amazonia (Glooer et al., 2013). Detailed reconstructions of paleoenvironmental and paleoclimate 
conditions contribute to validate these models and allow for an alternative approach by providing direct information of hydrological, biological and sedimentary processes against different climatic backgrounds of the past (Haywood et al. 2019).

Large rivers are ubiquitous elements of the Amazonian physical landscape, connecting climate with surface processes and sustaining unique aquatic and flooding forest ecosystems. However, large rivers in Eastern Amazonia have also been considered for hydroelectricity generation purposes through the installation of large dams (Latrubesse et al., 2017). While the human impact on climate and vegetation cover has raised multiple concerns about the future of Eastern Amazonia (Davidson et al. 2012), the accumulated negative impacts related current trend of hydropower expansion towards Amazonia may cause severe and disruptive impacts on sediment dynamics, ecology, and carbon cycling (Tranvik et al. 2009; Latrubesse et al. 2017). Clearwater Rivers from Eastern Amazonia, such as the Tapajós and the Xingu, are a critical example of how multifactorial anthropogenic impacts may threaten a natural system.

Over the last few decades, the drainage basins of both rivers have been subjected to intense deforestation (Durigan et al., 2013; Farella et al., 2001) and were severely affected by mining (Godfrey, 1992) and farming (Durigan et al., 2013). In addition, the recently installed Belo Monte and Teles Pires hydropower plants aroused immense concerns about the potential socio-environmental impacts of damming these rivers. The expansion of hydroelectric system towards Amazonia is commonly justified on the grounds that this is a low carbon source of energy (Latrubesse et al., 2017). However, several studies challenge this idea and propose that tropical reservoirs may not offer significant advantages in terms of greenhouse gas emissions when compared to fossil-fuel-based powerplants (e.g. Delmas et al., 2001; Abril et al., 2005; dos Santos et al., 2006; Faria et al., 2015). As such, better tools are needed for understanding natural processes and estimating the effect of anthropogenic forcing factors in the Amazonian environment.

\subsection{Objectives}

Despite the great sensitivity of clearwater rivers of Eastern Amazonia to anthropogenic impacts (Zemp et al., 2017), few studies tried to characterize the effects of climatic and human-related alterations in the discharge, sedimentary dynamics, and greenhouse gases emissions of the Xingu River. Hence, the overall goal of this work is an 
improved understanding of how different climate conditions and anthropogenic pressure affect river discharges and carbon dynamics in Eastern Amazonia. We investigated organic and inorganic proxies from sediment cores retrieved from the Lower Xingu Basin, in the Eastern Amazon, to identify hydrologic anomalies during the Late Holocene. Results obtained in this study may provide important insights to understand the impacts of future droughts in a changing climate. As a complementary approach, we also investigated carbon burial rates in the lower Xingu and Tapajós Rivers and the magnitude of methane emissions associated with the recent impoundment of the Xingu River by the Belo Monte hydropower plant, the largest hydropower project in Amazonia. These studies shed new light on how carbon dynamics from Amazonian clearwater rivers are affected by changes in discharge and other severe anthropogenic impacts such as the implementation of reservoirs for hydroelectricity generation.

The following questions formed the initial basis for the accomplishment of this thesis: (1) Did Late Holocene hydroclimate variations promote significant changes in riverine discharge within the Amazon lowlands? (2) Have these changes affected sediment dynamics in the Lower Xingu River? (3) How Amazonian Fluvial Rias, which are lake-like channels at the confluence of clearwater and blackwater tributaries with the Amazon River, affected riverine carbon dynamics in the Eastern Amazon? (4) To which extent is carbon cycling impacted by recent anthropogenic impacts, such as the construction of the Belo Monte Hydropower plant in the Xingu River?

To address these questions and to advance in the understanding of natural and anthropogenic processes acting in Eastern Amazonia, the following goals were addressed: (1) Identification of past changes in precipitation, vegetation, and river and sediment discharge in the Lowland Amazonia during the Late Holocene using inorganic (grain size, magnetic susceptibility and major elements) and organic proxies (distributions and isotope compositions of long-chain n-alkanes); (2) Improvement of the current knowledge regarding the dynamics of organic sediments deposited in Fluvial Rias of Eastern Amazonia through geochemical methods combined to luminescence and radiocarbon dating; and (3) Evaluation of carbon fluxes $\left(\mathrm{CO}_{2}\right.$ and $\left.\mathrm{CH}_{4}\right)$ in the Belo Monte reservoir area before and after the impoundment using floating and static chambers. 


\subsection{Thesis Outline}

This thesis is mainly composed of three manuscripts, which are either published or in preparation for submission in peer-reviewed scientific journals. Each article is individually understandable and presented as a chapter in the main text (Chapters 2, 3, and 4). Although the three manuscripts address the same subject, which is the investigation of causes and effects of hydrologic variations in Amazonia, each chapter evokes a different time frame. They also use distinct scientific approaches to characterize the outcomes of climatic and anthropogenic transformations in Eastern Amazonia during the Late Holocene. The study areas and methods are presented in detail in the succeeding chapters.

Chapter 2 (Erstwhile), discusses the effects of Late Holocene climatic variability on the water discharges of the Amazon and Xingu Rivers based on high-resolution sedimentary records of fluvial rias. This chapter presents the manuscript "Spatiotemporal variations of riverine discharge within the Amazon Basin during the Late Holocene coincide with extratropical temperature anomalies" (Published in Geophysical Research Letters).

Chapter 3 (Prelude), characterizes suspended and riverbed sediments from fluvial rias in Eastern Amazonia and discuss their potential role as a sink or source of carbon to the atmosphere. This chapter presents the manuscript "The fate of carbon in sediments of the Xingu and Tapajós Clearwater Rivers, Eastern Amazon" (Published in Frontiers in Marine Science).

Chapter 4 (Denouement), investigates the potential magnitude of carbon dioxide and methane emissions from the Belo Monte Reservoir area. We expect that this section will contribute to the understanding of how anthropogenic pressure may affect carbon dynamics in Amazonia. This chapter presents the manuscript: "Pre- and post-flooding emissions of methane and carbon dioxide from the Belo Monte reservoir area (Xingu River, Amazonia)". (In preparation for submission).

In Chapter 5, a brief integrative discussion is presented to summarize climatic and anthropogenic impacts in Eastern Amazonia through different time frames. 


\section{SPATIOTEMPORAL VARIATIONS OF RIVERINE DISCHARGE WITHIN THE AMAZON BASIN DURING THE LATE HOLOCENE COINCIDE WITH EXTRATROPICAL TEMPERATURE ANOMALIES}

Bertassoli Jr, D.J.; Sawakuchi, A.O.; Chiessi, C.M.; Schefuß, E.; Hartmann, G.A.; Häggi, C.; Cruz, F.W.; Zabel, M.; McGlue, M. M.; Santos, R.A.; Pupim F.N.

\subsection{Abstract}

Late Holocene hydroclimate variations have been extensively recognized in Amazonia, but the effects of such changes on riverine discharge within the Amazon lowlands are still poorly understood. We investigated a sediment core covering ca. 4,000 to $300 \mathrm{cal} \mathrm{yr}$ BP collected in the lower valley of the Xingu River (Xingu Ria) in an area under the influence of the Amazon River. Our results indicate a decrease in precipitation in the Amazon lowlands throughout the studied period and reduced input of coarser and potassium-rich Amazon River sediments to the confluence from about 2,600 to 1,400 cal yr BP. We suggest that lower temperatures in the extratropical Southern Hemisphere weakened the South American Summer Monsoon and led to a decrease in the water discharge of the Amazon River during this period.

\subsection{Plain Language Summary}

The variability of the Amazon River water discharge over the last millennia is still poorly understood. Sediments deposited in the lower valley of the Xingu River, a major eastern tributary of the Amazon River, allowed for the identification of a decrease in rainfall over the Amazon lowlands throughout the last 4,000 years. Changes in the relative input of Amazon and Xingu sediments in an area affected by both rivers indicate that the water discharge of the Amazon River decreased from about 2,600 to 1,400 years ago. We suggest that anomalously low temperatures in the Southern Hemisphere led to drier conditions in Amazonia during this period. 


\subsection{Introduction}

Precipitation in Amazonia is primarily modulated by variations in the strength of the South American Summer Monsoon (SASM) and by shifts of the Intertropical Convergence Zone (ITCZ) (Marengo, 2004; Garreaud et al., 2009). Changes in the sea surface temperatures (SST) of the Atlantic and Pacific Oceans severely affect the transport of moisture towards Amazonia and partially control the discharge of the Amazon River and its tributaries (Marengo \& Espinoza, 2016). Hydrologic variations in Amazonia have affected local communities and rainforest ecosystems over the last millennia (Meggers, 1994; Cordeiro et al., 2014, Marengo \& Espinoza, 2016). As such, it is critical to understand how the Amazon River and its tributaries responded to changes in Amazonian precipitation throughout the late Holocene (i.e., last 4,000 yr). Still, deciphering hydroclimatic imbalances in Eastern Amazonia is challenging. Speleothems are scarce in this area and sediment cores collected offshore of the Amazon River mouth may not reveal internal hydrological variability due to the overwhelming Andean signature in the sediment supply (Govin et al., 2014; Höppner et al., 2018). Similarly, autogenic processes such as river avulsions limit comprehensive discussions about water discharge variations based on sediment cores from floodplain lakes (e.g. Aniceto et al., 2014).

In the Xingu River, a major clearwater tributary of the Amazon River, seasonal and tidal oscillations affect water level gradients and modulate flow velocities near its confluence with the Amazon main stem (Fricke et al., 2017). Peak discharge in the Amazon River (about $200,000 \mathrm{~m}^{3} \mathrm{~s}^{-1}$ ) occurs when the Xingu River discharge is already at its falling stage (JuneJuly), reversing water level gradients in the confluence zone (Fricke et al., 2017). Thus, water levels in the lowermost Xingu River are mainly controlled by the Amazon River stage (Figure S1). Variations in the relative discharge of the Amazon and Xingu rivers promote barotropic and baroclinic flows that carry Amazon River waters plus sediments into the lower reach of the Xingu River (Fricke et al., 2017). Some of these sediments are deposited in the lake-like Xingu Ria, a broad, drowned incised valley of the Xingu River (Figure 1), and may help to identify hydrologic changes in the catchments of the Amazon and Xingu rivers (Fricke et al., 2017).

In order to reconstruct regional hydroclimate variability over the last millennia, we investigated a sediment core collected in the lowermost section of the Xingu Ria. We analyzed the hydrogen $(\delta \mathrm{D})$ and stable carbon $\left(\delta^{13} \mathrm{C}\right)$ isotope compositions of long-chain $n$ alkanes to infer changes in paleoprecipitation and vegetation. We also used grain size, 
magnetic susceptibility and major elements measured in sediments of the Amazon and Xingu rivers to reconstruct changes in the relative influx of Amazon River sediments to the Xingu Ria. We compared the obtained results to abrupt changes in a sediment core retrieved from a floodplain lake outside of the Amazon River influence. Our results provide important insights about relative river discharges in eastern versus western Amazonia throughout the late Holocene.

\subsection{Study Area}

The Xingu is a large clearwater river draining Eastern Amazonia (Figure 1a). It has a mean annual water discharge of $9,700 \mathrm{~m}^{3} \mathrm{~s}^{-1}$ (Latrubesse et al., 2005) and marked seasonality, with discharge varying from $1,000 \mathrm{~m}^{3} \mathrm{~s}^{-1}$ (September-October) to $19,000 \mathrm{~m}^{3} \mathrm{~s}^{-1}$ (March-April) (Figure S1, ANA, 2017). Whereas rainfall in the Lower Xingu is governed by persistent easterly winds that bring moisture from the Atlantic Ocean, precipitation in the Upper Xingu is strongly related to the SASM (Figure S2, ANA, 2017).

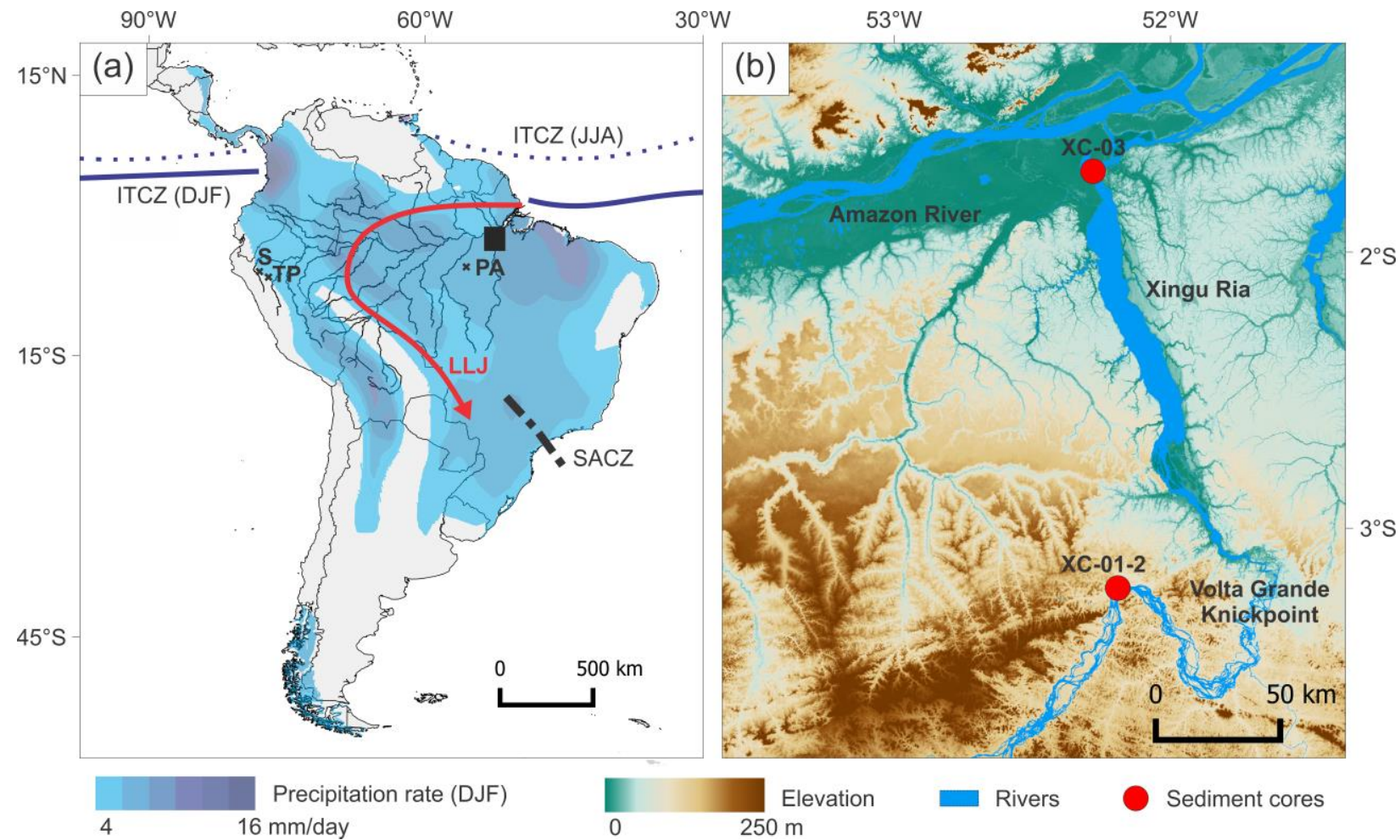

Figure 1 - Study area and sampling sites of sediment cores XC-03 and XC-01-2. (a) Schematic representation of the South Atlantic Convergence Zone (SACZ) and ITCZ. The simplified trajectory of the Low-Level Jet (LLJ) is also shown. Blue-shaded areas cover regions with average precipitation rates $>4 \mathrm{~mm}$ /day during austral summer. The locations of the Paraíso (PA, Wang et al., 2017), Tigre Perdido (TP, van Breukelen et al., 2008) and Shatuca records (S, Bustamante et al., 2016) are also indicated. DJF: December-February; JJA: June-August. A black square depicts the study area detailed in (b). (b) Digital elevation model of the lower reaches of the Amazon and Xingu rivers (SRTM, Farr et al., 2007) and sites of the studied sediment cores. ITCZ = Intertropical Convergence Zone; SRTM = Shuttle Radar Topography Mission. 
The Xingu River shows a variety of fluvial channel morphologies, with a meandering channel at its upper catchment, a bedrock channel with multiple flow paths at its mid portion (Wohl \& Merritt, 2001), and a fluvial ria in its downstream section (Archer, 2005). Upstream of the Xingu Ria, a bedrock anastomosing system known as Volta Grande do Xingu ("Xingu Great Bend", Figure 1b) comprises channels with rapids flowing above fractured basement rocks (Sawakuchi et al., 2015). Besides being a unique environment for Amazonian biodiversity (Nogueira et al., 2010), those rapids act as a major knickpoint and limit the influence of the Amazon River to upstream portions of the Xingu watershed.

As the Xingu River mainly drains Proterozoic and Archean rocks of the Central Brazilian Shield or their derived-sedimentary cover (Almeida et al., 1981), topography, weathering conditions, denudation patterns $\left(6-15 \times 10^{-3} \mathrm{~mm} / \mathrm{yr}\right.$, Wittmann et al. 2011, Sawakuchi et al. 2015) and geological substrates of the Xingu watershed are markedly different from Andean-draining tributaries of the Amazon River (Konhauser et al., 1994; Guyot et al., 2007; Sawakuchi et al., 2018). These distinctions are manifested in the relatively low particulate load and high proportions of stable and conservative elements in both suspended and riverbed sediments of the Xingu River (Filizola \& Guyot, 2009; Bertassoli et al., 2017). Thus, it is possible to geochemically trace the influence of Amazon River sediments in the Lower Xingu Ria.

\subsection{Materials and Methods}

We investigated two sediment cores (XC-03 and XC-01-2) collected in the Lower Xingu River. XC-03 is a $362 \mathrm{~cm}$-long percussion core obtained from the Xingu Ria, close to the confluence with the Amazon River (0142’32.12”S, 52॰16'47.42”W, Figure 1b). It was retrieved by divers at a water depth of $10 \mathrm{~m}$. The XC-03 core consists of relatively homogeneous fine-grained gray sediments (mainly clay and silt). Sediment core XC-01-2 was retrieved from a seasonally inundated lake within a fluvial island upstream of the Volta

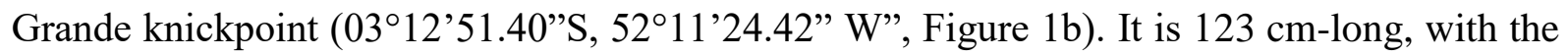
lowermost portion $(80-123 \mathrm{~cm})$ composed of medium to coarse sand with fining upward pattern. Fine-grained (silt and clay) brown and dark-gray sediments are dominant in the upper portion $(0-80 \mathrm{~cm})$ of XC-01-2. Radiocarbon $\left({ }^{14} \mathrm{C}\right)$ ages of the bulk organic fraction (Tables S1 and S2, $n=7$ for XC-03, $n=4$ for XC-01-2) were obtained by Accelerator Mass Spectrometry (AMS) dating at Beta Analytic Incorporated and Radiocarbon Laboratory of Federal Fluminense University (LAC-UFF). Radiocarbon dating was constrained by the availability of 
organic material in core $\mathrm{XC}-01-2$ and therefore the age model for this core is limited to the $20-80 \mathrm{~cm}$ interval. Further considerations regarding the age models are presented in the Supplementary Material (Text S1).

For long-chain $n$-alkane analysis, approximately $10 \mathrm{~g}$ of sediments were collected every $12 \mathrm{~cm}$ from core $\mathrm{XC}-03$ and $5 \mathrm{~cm}$ from core $\mathrm{XC}-01-2$. The extraction procedure is described in the Supplementary Material (Text S1). The $n$-alkane fraction was analyzed in a Thermo-Fisher Scientific Focus gas chromatograph equipped with a flame ionization detector. Hydrocarbons of different chain lengths were quantified by comparing peak areas of the compounds to external standards. Precision of compound quantification is about $5 \%$ based on multiple standard analyses. The carbon preference index $\left(\mathrm{CPI}_{25-33}\right)$ and the average chain length ( $\left.\mathrm{ACL}_{27-33}\right)$ were calculated using the relative distribution of $n$-alkanes (equations are presented in the Supplementary Material, Text S1). The low $\mathrm{CPI}_{25-33}$ values obtained from $\mathrm{XC}-01-2$ samples (Figure S5) make interpretations based on compound-specific isotopes impossible for this core. Hence, analyses of $\delta \mathrm{D}$ and $\delta^{13} \mathrm{C}$ of the $\mathrm{C}_{29}$ and $\mathrm{C}_{31} n$-alkanes were only conducted for core XC-03, which had $\mathrm{CPI}_{23-33}$ values generally above 4 (Figure S6).

We analyzed the $\delta \mathrm{D}$ of the $\mathrm{C}_{29}$ and $\mathrm{C}_{31} n$-alkanes as a proxy for changes in past precipitation (Häggi et al., 2017) on a Thermo-Fisher Scientific MAT 253 isotope ratio mass spectrometer coupled via a GC Isolink operated at $1420{ }^{\circ} \mathrm{C}$ to a Thermo-Fisher Scientific Trace GC. Daily determination of the $\mathrm{H}^{+}{ }_{3}$ factor varied between 5.1 and 5.2 over the analysis period. All $\delta \mathrm{D}$ analyses were made against calibrated $\mathrm{H}_{2}$ reference gas and $\delta \mathrm{D}$ values are reported in \%o against Vienna Standard Mean Ocean Water. Given the investigated period (i.e., late Holocene), an ice volume correction was not required.

Analyses of $\delta^{13} \mathrm{C}$ of long-chain $n$-alkanes, used to reconstruct variations in past vegetation cover (e.g. Castañeda \& Schouten, 2011), were carried out on a Thermo-Fisher Scientific MAT 252 isotope ratio mass spectrometer coupled via a GC-C combustion interface with a nickel catalyzer operated at $1000{ }^{\circ} \mathrm{C}$ to a Thermo-Fisher Scientific Trace GC. The analyses were conducted against calibrated $\mathrm{CO}_{2}$ reference gas of known isotopic composition and $\delta^{13} \mathrm{C}$ values are given in \%o against Vienna Pee Dee Belemnite.

Measurements were made in duplicate and accuracy was controlled for each measurement using the internal squalene standard with known isotopic composition $(-180.3 \pm 2.3 \%$ for $\delta \mathrm{D}$ and $-19.8 \pm 0.2 \%$ for $\delta^{13} \mathrm{C}$ ). The average values obtained for the internal standard during analyses were $-179.5 \pm 3.1 \%$ o $(\delta \mathrm{D})$ and $-20.0 \pm 0.4 \%$ o $\left(\delta^{13} \mathrm{C}\right)$. Precision was controlled by external $n$-alkane standards $\left(\mathrm{C}_{16}\right.$ to $\mathrm{C}_{34}$, ) at every six measurements. Repeated analyses of external $n$-alkane standards yielded a root-mean-squared deviation of $2.2 \%$ for $\delta \mathrm{D}$ and $0.1 \%$ 
for $\delta^{13} \mathrm{C}$, respectively. Given the similar behavior of $\delta \mathrm{D}$ values from $\mathrm{C}_{29}$ and $\mathrm{C}_{31} n$-alkanes in $\mathrm{XC}-03$ (Figure $\mathrm{S7}$ ), results are presented as the weighted average of the two compounds ( $\delta \mathrm{D}$ $\left.\mathrm{C}_{29-31}\right)$.

We collected sediment aliquots (10 g) from cores XC-03 and XC-01-2 at every $2 \mathrm{~cm}$ for grain size and X-ray fluorescence (XRF) analyses ( $n=174$ for XC-03, $n=40$ for XC-012). Grain size distributions of XC-03 samples $(n=174)$ were determined using a laser diffraction particle size analyzer equipped with a wet sample dispersion unit (Malvern Instruments Ltd, Mastersizer 2000 and Hydro 2000 MU). Samples were directly dispersed in $900 \mathrm{ml}$ of deionized water using an ultrasonic bath (one minute) and sodium pyrophosphate as dispersion agent before measurements. Precision standards for this method are described in Miller \& Schaetzl (2012).

Samples for XRF analyses were dried, ground, and sealed in inert sample cups covered with ultra-thin mylar. Measurements were made using a Bruker Titan S1 handheld XRF device (6-50 kV, 4.5-195 $\mu \mathrm{A})$ for XC-03 and a Bruker Tracer IV-SD handheld energydispersive XRF $(40 \mathrm{kV}, 60 \mu \mathrm{A})$ for $\mathrm{XC}-01-2$. Individual $\mathrm{XRF}$ scans were made over 60 seconds for $\mathrm{XC}-03$ and 90 seconds for XC-01-2. Internal consistency was verified by routine scanning of a standard. The coefficient of variation was below $5.0 \%$ for all analyzed elements (i.e., $\mathrm{Al}, \mathrm{Si}, \mathrm{K}, \mathrm{Ti}, \mathrm{Fe}, \mathrm{Mn}$ ).

We also retrieved 141 samples from XC-03 using cubic plastic boxes $\left(8 \mathrm{~cm}^{3}\right)$ placed side-by-side for magnetic susceptibility measurements. Low-field magnetic susceptibility of discrete samples was measured using an Agico Kappabridge MFK1-FA system under different frequencies (976 and $15616 \mathrm{~Hz}$ ) in a $200 \mathrm{Am}^{-1}$ field at room temperature (e.g. Dearing et al., 1996, Ustra et al., 2018). Frequency-dependent susceptibility ( $\chi \mathrm{fd} \%$ ) was calculated from the difference between low- and high-frequency susceptibility values, enabling an evaluation of the spectrum of grain sizes of single-domain to superparamagnetic grains in the samples. Individual results were mass normalized and coefficient of variation was below $0.5 \%$ for the analyzed frequencies.

\subsection{Results and Discussion}

\subsubsection{Age models}

The age model of core XC-03 suggests no major changes in sediment accumulation and covers the period from ca. 4,000 to $300 \mathrm{cal}$ yr BP (Figure S3). Sedimentation rates range 
from 0.5 to $1.4 \mathrm{~mm} \mathrm{yr}^{-1}$ and yield an average temporal resolution of 20 years for geochemical, grain size and magnetic susceptibility records. Grain size and major element distribution do not show abrupt shifts that could indicate hiatuses in accumulation (Figure S9 and S10).

Core XC-01-2 responds exclusively to the sediment supply and hydrology of the Xingu River watershed. These results differ from XC-03, which provides direct information on the sediment supplies from both Amazon and Xingu rivers. Ages obtained from core XC01-2 span from ca. 2,800 to 400 cal yr BP (Figure S4). Sedimentation rates are, on average, significantly lower than in the Xingu Ria, varying from about 0.14 to $0.77 \mathrm{~mm} \mathrm{yr}^{-1}$ in the upper deposit (0-80 cm depth).

\subsubsection{Amazon lowlands precipitation during the late Holocene}

Analyses of the organic fraction show that $\mathrm{C}_{29}$ and $\mathrm{C}_{31}$ are the dominant $n$-alkanes in core XC-03, with respective average concentrations of $0.4 \pm 0.1$ and $0.5 \pm 0.2 \mu \mathrm{g} \mathrm{g}^{-1}$ (dry sediment). The XC-03 record presents average $\delta^{13} \mathrm{C}$ of $-33.7 \pm 0.3 \%$ for $\mathrm{C}_{29}$ and $-34.5 \pm 0.2$ $\%$ for $\mathrm{C}_{31}$ and shows constant dominance of $\mathrm{C}_{3}$ vegetation throughout the late Holocene (Figure 2d). Riverbed sediments from the Amazon main stem and Andean tributaries exhibit more ${ }^{13} \mathrm{C}$-enriched signatures (average $\delta^{13} \mathrm{C}$ between -35 and $-33 \%$ ) than the Xingu River (average $\delta^{13} \mathrm{C}$ more depleted than $-35 \%$ ) (Häggi et al., 2016). The $\delta^{13} \mathrm{C}$ of $n$-alkanes from XC-03 differ from the typical signatures of the Xingu River sediments and suggest that the organic material reaching the studied site is predominantly derived from the Amazon River. The weighted average of $\delta \mathrm{D}$ from XC- $03 \mathrm{C}_{29}$ and $\mathrm{C}_{31} n$-alkanes range from about -151 to -163 $\%$, with a slight trend of increasing values towards the present (Figure $2 \mathrm{a}$ ). The $\delta \mathrm{D}$ results are also within the range presented by Häggi et al. (2016) for riverbed samples from the Amazon River (-152 to $-165 \%$ ).

Plant leaf-waxes in sediments of the Amazon River are spatially-integrated (Feakins et al., 2018), and the Amazon lowlands are the dominant source area of organic material and plant-waxes to the lower Amazon River (Häggi et al., 2016; Ponton et al., 2014; Bouchez et al., 2014). Hence, we interpret the $\delta D C_{29-31}$ record from $X C-03$ to represent $\delta D$ variations of regional meteoric water, which are mainly controlled by the precipitation amount in the Amazon lowlands (Häggi et al., 2016, 2017).

Considering that $\mathrm{XC}-03 \delta^{13} \mathrm{C}$ values point to a relatively stable vegetation cover (Figure 2d), we assume that evapo-transpirative enrichment and changes in vegetation metabolism and sediment sourcing did not exert a significant effect on the $\delta \mathrm{D}$ values of long- 
chain $n$-alkanes variability through the late Holocene. The stable $\mathrm{ACL}_{27-33}(30.2 \pm 0.1)$ and $\mathrm{CPI}_{25-33}(4.4 \pm 0.2$.) in $\mathrm{XC}-03$ sediments suggest that degradation and input of petrogenic (fossil) material also have insignificant effects on the $\delta \mathrm{D} \mathrm{C}_{29-31}$ and $\delta^{13} \mathrm{C}$ records (Figure S6).

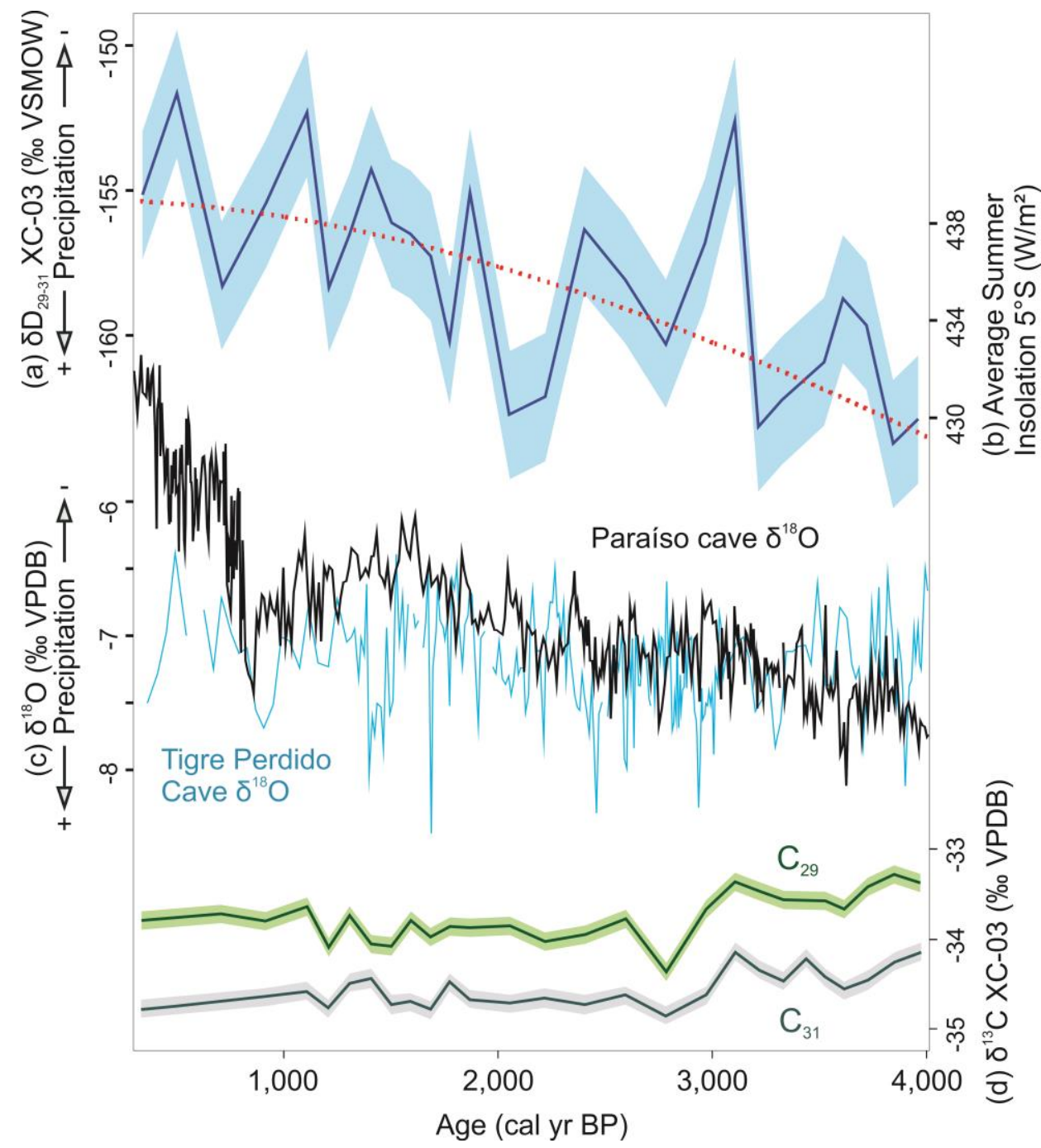

Figure 2 - Paleoenvironmental proxies from core XC-03 in the Xingu-Amazon rivers confluence compared to Amazonian speleothems records. (a) Weighted average of the $\delta \mathrm{D}$ of long-chain $n$-alkanes $\left(\mathrm{C}_{29}\right.$ and $\left.\mathrm{C}_{31}\right)$ from core XC-03. (b) Average austral summer insolation at $5^{\circ} \mathrm{S}$ (Laskar et al., 2004) (c) Speleothem $\delta^{18} \mathrm{O}$ records from Paraíso Cave (black, Wang et al., 2017) and from Tigre Perdido Cave (light blue, van Breukelen et al., 2008), as proxies for precipitation over eastern and western Amazonia, respectively. (d) $\delta^{13} \mathrm{C}$ of $n$-alkanes $\mathrm{C}_{29}$ and $\mathrm{C}_{31}$ from core $\mathrm{XC}-03$, values are relatively stable and indicate a strong dominance of $\mathrm{C} 3$ vegetation. In (a) and (d), shaded areas represent the $2 \sigma$ uncertainty envelope of isotopic values obtained by repeated analyses of external $n$-alkane standards.

The XC-03 $\delta \mathrm{D} \mathrm{C}_{29-31}$ record suggests that Eastern Amazonia (i.e. the Amazon lowlands) experienced a decrease in precipitation throughout the late Holocene (Figure 2a). These results follow an increase in average austral summer insolation (Figure 2b) and differ from paleoprecipitation records from the Andes and western Amazonia (e.g. Figure 2c, Baker et al., 2001). The antiphase variability behavior between eastern and western Amazonia on the 
orbital timescale has been interpreted as a product of an increased sea-land thermal gradient and atmospheric convection (Cheng et al., 2013).

Both the XC-03 $\delta \mathrm{D} \mathrm{C} \mathrm{C}_{29-31}$ and Paraíso Cave $\delta^{18} \mathrm{O}$ records (Figure 2a, 2c) suggest that a trend of decreasing humidity prevailed in a significant part of the Amazon lowlands during the late Holocene. Western Amazonian (Andean) precipitation is relatively stable during this period (Figure 2c, Bird et al., 2011), highlighting persistent heterogeneous precipitation trends among different regions of the Amazon Basin. The contrasting east-west precipitation trends are also evident in neodymium isotopic record, which suggest a shift in the Amazon River sediment supply towards a greater Andes-dominated signal during the late Holocene (Höppner et al., 2018).

\subsubsection{Multi-centennial anomalies on the discharge of the Amazon and Xingu rivers}

Variations in grain size, major elements, and $\chi \mathrm{fd} \%$ in core $\mathrm{XC}-03$ (Figure 3b-d) suggest significant changes in the relative sediment supply of the Amazon and Xingu rivers to the Xingu Ria. The percentage of fine-grained sediments and $\mathrm{Fe} / \mathrm{K}$ ratios in $\mathrm{XC}-03$ increase after 3,600 cal yr BP and reach maximum values between 2,600 and 1,400 cal yr BP (Figures $3 \mathrm{~b}, 3 \mathrm{~d})$. A marked increase in $\chi \mathrm{fd} \%$ around 2,700 yr BP agrees with most of the changes in the distribution of major elements and grain size (Figure 3c). A synchronous shift in magnetic susceptibility and Si/Al is also evident in core XC-01-2 (Figures S12 and 3a). 


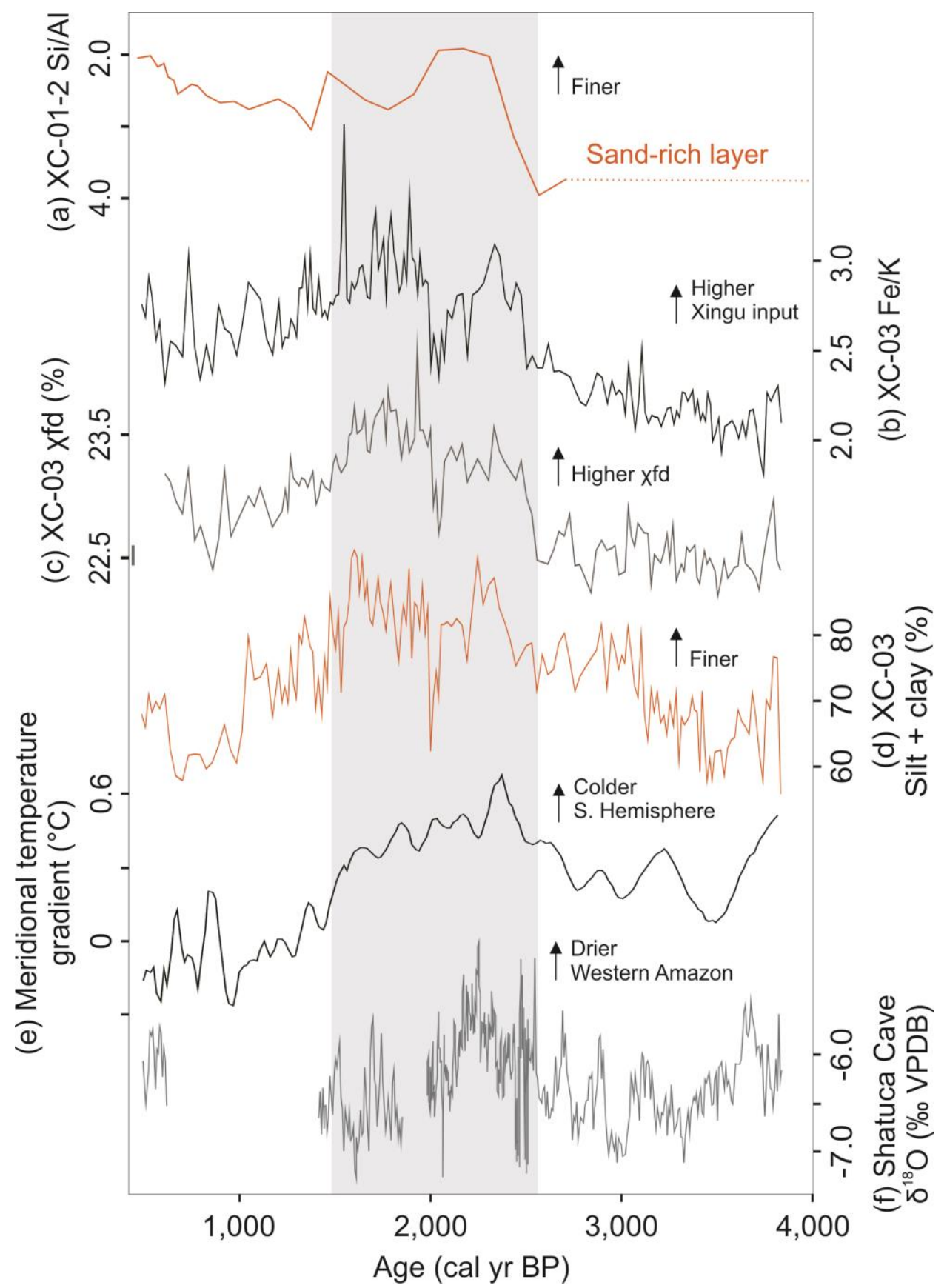

Figure 3 - Comparison of the XC-03 and XC-01-2 records with other paleoclimate records. Si/Al values in core XC-01-2 (a) and XC-03 Fe/K values (b), frequency-dependent magnetic susceptibility (c) and fine-grained (silt and clay) sediment content (d). (e) Extratropical temperature gradient between the Northern and Southern Hemispheres (Marcott et al., 2013) (f) Speleothem $\delta^{18} \mathrm{O}$ record from Shatuca Cave, representing changes in precipitation in the northeastern flank of the Peruvian Andes in western Amazonia (Bustamante et al., 2016). The gray vertical bar highlights coincident shifts in the depicted records.

$\mathrm{Fe} / \mathrm{K}$ values have been used as a provenance proxy for distinguishing sediments from the Amazon River main stem and lowland-draining tributaries (Govin et al., 2014; Häggi et al., 2016). Modern riverbed and suspended sediments from the Amazon River present $\mathrm{Fe} / \mathrm{K}$ values around 2, while sediments from the Xingu River range from 3 to 27, depending on season (Bertassoli et al., 2017; Zhang et al., 2017; Sawakuchi et al., 2018). Thus, the increase 
in $\mathrm{Fe} / \mathrm{K}$ values, frequency-dependent magnetic susceptibility and silt and clay content in $\mathrm{XC}$ 03 indicate diminished relative proportions of coarser Amazon River sediments reaching the studied site (Figure 3b-d).

Although fluctuations in the weathering intensity of sediment sources could have affected geochemical XC-03 records, we deem this process less probable of producing the described trends. Indeed, variations in $\mathrm{Fe} / \mathrm{K}$ values of Amazon River sediments obtained by Zhang et al. (2017) during periods of major changes in western Amazonian precipitation (Heinrich and Dansgaard-Oeschger stadials) were rather subtle when compared to the fluctuations in our data. Potential effects of major late Holocene physiographic changes on sediment grain size and $\mathrm{Fe} / \mathrm{K}$ values are unlikely, considering the correspondence between changes recorded in cores XC-03 and XC-01-2 and other regional paleoclimate records (e.g. Figure S13). Additionally, the lower portion of the Xingu Ria is bound by stable Pleistocene terraces (Pupim et al., 2016), precluding major variations in channel morphology during the Holocene.

We interpret that periods of reduced contribution of Amazon River sediments to the XC-03 site can be caused by two processes: (i) a diminished efficiency of the backwater effect in the confluence of the Amazon and Xingu rivers; and (ii) a more downstream position of the mixing zone of Amazon and Xingu waters, which would increase the distance of the XC-03 site from the confluence. Both processes are modulated by changes in the Amazon/Xingu discharge ratios (Best, 1988; Dixon et al., 2018) and suggest a decrease in the Amazon River discharge relative to the discharge of the Xingu River from 2,600 to 1,400 cal yr BP.

Riverbed sediments in Amazon rivers show a strong positive correlation between $\mathrm{Si} / \mathrm{Al}$ values and grain size that reflects the proportion of aluminum-rich clay minerals in relation to silicon-rich sand (Bouchez et al., 2011; Sun et al., 2017). A shift towards lower $\mathrm{Si} / \mathrm{Al}$ values in XC-01-2 (Figure 3a) indicates that at about 2,700 cal yr BP, sand bar deposits were superimposed by aluminum-rich fine-grained lacustrine sediments. The observed grainsize pattern is synchronous to an increase in magnetic susceptibility (Figure S12) and consistent with the establishment of calm water conditions atop a stabilized sand bar depression during an interval of decreased discharge of the Xingu River. The synchronicity of major geochemical changes in XC-03 and XC-01-2 from 2,600 to 1,400 cal yr BP indicates that although the discharge of the Amazon mainstem decreased relative to the Xingu River, the discharge of both rivers were likely lower during this period (Figure 3a-d).

The anomalies seen in cores XC-03 and XC-01-2 coincide with multi-centennial dry events and a slight shift in precipitation trends in western Amazonia (e.g. Figures 3f, Bird et 
al., 2011; Kanner et al., 2013; Bustamante et al., 2016). Thus, decreased SASM intensity from 2,600 to 1,400 cal yr BP may have contributed to anomalous water discharges in the Amazon and Xingu rivers, affecting their sediment loads and relative discharge ratios. This, in turn, dampened the backwater effect and possibly moved the mixing zone of the Amazon and Xingu rivers towards a more downstream position.

The correspondence of the XC-03 and Shatuca cave $\delta^{18} \mathrm{O}$ records with the reconstructed hemispheric temperature gradient (Marcott et al., 2013) suggest that the meridional temperature gradient was an important forcing of changes in SASM intensity during the late Holocene (Figure 3b-f). Importantly, most of the variability controlling the negative anomaly in the meridional temperature gradient from 2,600 to 1,400 cal $\mathrm{yr} \mathrm{BP}$ (Figure 3e) is related to anomalous multi-centennial cold events in Antarctica and the Southern Ocean (Figure S13, Rosqvist \& Schuber, 2003; Nielsen et al., 2004; Bentley et al., 2009; Masson et al., 2000; Shevenell et al., 2011). The teleconnections of extratropical cooling and tropical rainfall intensity mediated by interhemispheric thermal gradients are thoroughly discussed in Chiang \& Friedman (2012).

Although previous studies have mainly focused on North Atlantic SST variability forcing on SASM intensity, our data suggest that extratropical South Hemisphere temperatures may also have played an important role in controlling Amazonian rainfall patterns during the late Holocene. More specifically, the negative anomaly of the meridional temperature gradient (Figure 3e) would produce a northward displacement of the ITCZ or a limitation of the seasonal southward migration of the ITCZ during austral summer (Figure S14, Schneider et al., 2014), significantly decreasing precipitation in western Amazonia. Indeed, several Caribbean records suggest a more stable northern position of the ITCZ from about 2,400 to 1,250 cal yr BP (e.g. Figure S13, Donnelly \& Woodruff, 2007; Malaizé et al., 2011).

Variations in the meridional temperature gradient promoted spatially heterogeneous rainfall changes over different timescales in the Amazon Basin (i.e. Marengo et al., 2008; Chiessi et al., 2009; Zhang et al., 2017). In 2005, an anomalous northward displacement of the ITCZ linked to warmer SST in the tropical North Atlantic contributed to one of the most intense droughts recorded in western Amazonia (Marengo et al., 2008; Panisset et al., 2018; Zeng et al., 2008). During this event, while western tributaries of the Amazon River had their water discharges dramatically reduced, tributaries of central and Eastern Amazonia were marginally affected (Marengo et al., 2008). Considering the recent trend towards more intense droughts in Amazonia (Lopes et al., 2016), the anomalous conditions from 2,600 to 1,400 cal 16 
yr BP may serve as an important analogue to understand the impacts of future droughts in a changing climate. Additionally, our findings can contribute to discussions regarding the impact of multi-centennial climatic events in technological changes and in the regional increase in human activity and socio-political complexity around 2,500-2,000 cal yr BP in Amazonia (Heckenberger \& Neves, 2009, Maezumi et al., 2018).

\subsection{Conclusions}

Our results show that sediments accumulated in Amazonian fluvial rias provide useful information to disentangle the response of the Amazon River and its tributaries to hydrological changes during the late Holocene. The $\delta \mathrm{D} \mathrm{C}_{29-31}$ record from core $\mathrm{XC}-03$ suggests an overall drying trend in the Amazon lowlands throughout the last 4,000 yr that contrasts with western Amazonian precipitation proxies. The marked increase (decrease) in $\mathrm{Fe} / \mathrm{K}$ (grain size) from 2,600 to 1,400 cal yr BP indicates relatively lower input of Amazon River sediments into the Xingu Ria and reveal a multi-centennial dry event in Amazonia that departs from the insolation-controlled trend. We suggest that changes in the meridional temperature gradient linked to lower temperatures in the extratropical Southern Hemisphere sustained a more northern position of the ITCZ from 2,600 to 1,400 cal yr BP. This, in turn, weakened SASM-related rainfall in Amazonia and decreased the discharge of the Amazon River relative to the discharge of the Xingu River during this period. Our records document spatially heterogeneous rainfall changes in Amazonia linked to insolation and interhemispheric temperature anomalies.

\subsection{Acknowledgments}

The authors acknowledge funding through the São Paulo Research Foundation (FAPESP) (grants \#2017/50085-3, \#2014/23334-4, \#2016/11141-2, \#2016/02656-9 and \#2017/25735-4), Brazilian Federal Agency for Support and Evaluation of Graduate Education (CAPES) (grants AUXPE 1976/2014, 2043/2014 and 564/2015) and National Council for Scientific and Technological Development (CNPq) (grants \#454609/2014-0, \#302607/2016-1, \#422255/2016-5, \#306527/2017-0 and \#302411/2018-6). This work was supported through the DFG Research Center/Cluster of Excellence "The Ocean in the Earth System". We thank the Paleomagnetism Laboratory (USPMag) of the University of São Paulo (Brazil). We acknowledge Ralph Kreutz for laboratory support, Daniel Atencio for providing the XRF 
equipment, and Mauricio Parra, Tatiana Pereira and Leandro Souza for helping during the field surveys.

All data presented in this study is permanently archived on the Pangaea data repository (www.pangaea.de).

The authors declare no conflict of interest.

\subsection{References}

Almeida, F. F. M. de, Hasui, Y., Brito Neves, B. B. de, \& Fuck, R. A. 1981. Brazilian Structural Provinces : An Introduction. Earth-Science Reviews, 17, 1-29. 10.1016/00128252(81)90003-9

ANA. 2017. Hidroweb: Sistema de Informações Hidrológicas. Retrieved in August 1, 2017 from http://www.snirh.gov.br/hidroweb/.

Aniceto, K., Moreira-Turcq, P., Cordeiro, R. C., Fraizy, P., Quintana, I., \& Turcq, B. 2014. Holocene paleohydrology of Quistococha Lake (Peru) in the upper Amazon Basin: Influence on carbon accumulation. Palaeogeography, Palaeoclimatology, Palaeoecology, 415, 165-174. 10.1016/j.palaeo.2014.08.018.

Archer, A. W. 2005. Review of Amazonian Depositional Systems. In Fluvial Sedimentology VII, 17-39. Oxford, UK: Blackwell Publishing Ltd. 10.1002/9781444304350.ch2.

Baker, P. A, Seltzer, G. O., Fritz, S. C., Dunbar, R. B., Grove, M. J., Tapia, P. M., et al. 2001. The history of South American tropical precipitation for the past 25,000 years. Science, 291(5504), 640-643. 10.1126/science.291.5504.640.

Bentley, M. J., Hodgson, D. A., Smith, J. A., Cofaigh, C. Ó., Domack, E. W., Larter, R. D., et al. 2009. Mechanisms of Holocene palaeoenvironmental change in the Antarctic Peninsula region. Holocene, 19(1), 51-69. 10.1177/0959683608096603.

Bertassoli, D. J., Sawakuchi, A. O., Sawakuchi, H. O., Pupim, F. N., Hartmann, G. A., McGlue, M. M., et al. 2017. The Fate of Carbon in Sediments of the Xingu and Tapajós Clearwater Rivers, Eastern Amazon. Frontiers in Marine Science, 4. 10.3389/fmars.2017.00044. 
Best, J. L. 1988. Sediment transport at river channel confluences. Sedimentology, 35, 481498. 10.1111/j.1365-3091.1988.tb00999.x.

Bird, B. W., Abbott, M. B., Rodbell, D. T., \& Vuille, M. 2011. Holocene tropical South American hydroclimate revealed from a decadally resolved lake sediment $\delta 180$ record. Earth and Planetary Science Letters, 310(3-4), 192-202. 10.1016/j.epsl.2011.08.040.

Bouchez, J., Gaillardet, J., France-Lanord, C., Maurice, L., \& Dutra-Maia, P. 2011. Grain size control of river suspended sediment geochemistry: Clues from Amazon River depth profiles. Geochemistry, Geophysics, Geosystems, 12(3), 1-24. 10.1029/2010GC003380.

Bouchez, J., Galy, V., Hilton, R. G., Gaillardet, J., Moreira-Turcq, P., Pérez, M. A., et al. 2014. Source, transport and fluxes of Amazon River particulate organic carbon: insights from river sediment depth-profiles. Geochimica et Cosmochimica Acta, 133, 280-298.

van Breukelen, M. R., Vonhof, H. B., Hellstrom, J. C., Wester, W. C. G., \& Kroon, D. 2008. Fossil dripwater in stalagmites reveals Holocene temperature and rainfall variation in Amazonia. Earth and Planetary Science Letters, 275(1-2), 54-60. 10.1016/j.epsl.2008.07.060.

Bustamante, M. G., Cruz, F. W., Vuille, M., Apaéstegui, J., Strikis, N., Panizo, G., et al. 2016. Holocene changes in monsoon precipitation in the Andes of NE Peru based on d18O speleothem records. Quaternary Science Reviews, 146, 274-287. 10.1016/j.quascirev.2016.05.023.

Castañeda, I. S., \& Schouten, S. 2011. A review of molecular organic proxies for examining modern and ancient lacustrine environments. Quaternary Science Reviews, 30(21-22), 2851-2891. 10.1016/j.quascirev.2011.07.009.

Chiang, J. C., \& Friedman, A. R. 2012. Extratropical cooling, interhemispheric thermal gradients, and tropical climate change. Annual Review of Earth and Planetary Sciences, 40, 383-412. 10.1146/annurev-earth-042711-105545.

Cheng, H., Sinha, A., Cruz, F. W., Wang, X., Edwards, R. L., D’Horta, F. M., et al. 2013. Climate change patterns in Amazonia and biodiversity. Nature Communications, 4, 1411. 10.1038/ncomms2415. 
Chiessi, C. M., Mulitza, S., Pätzold, J., Wefer, G., \& Marengo, J. A. 2009. Possible impact of the Atlantic Multidecadal Oscillation on the South American summer monsoon. Geophysical Research Letters, 36(21), 1-5. 10.1029/2009GL039914.

Cordeiro, R. C., Turcq, B., Moreira, L. S., Rodrigues, R. de A. R., Lamego Simões Filho, F. F., Martins, G. S., et al. 2014. Palaeofires in Amazon: Interplay between land use change and palaeoclimatic events. Palaeogeography, Palaeoclimatology, Palaeoecology, 415, 137-151. 10.1016/j.palaeo.2014.07.020.

Dearing, J. A., Dann, R. J. L., Hay, K., Lees, J. A., Loveland, P. J., Maher, B. A., \& O'grady, K. 1996. Frequency-dependent susceptibility measurements of environmental materials. Geophysical Journal International, 124(1), 228-240. 10.1111/j.1365246X.1996.tb06366.x.

Dixon, S. J., Sambrook, S. G. H., Best, J. L., Nicholas, A. P., Bull, J. M., Vardy, M. E., et al. 2018. The planform mobility of river channel confluences: Insights from analysis of remotely sensed imagery. Earth-Science Reviews, 176, 1-18. 10.1016/j.earscirev.2017.09.009.

Donnelly, J. P., \& Woodruff, J. D. 2007. Intense hurricane activity over the past 5,000 years controlled by El Niño and the West African monsoon. Nature, 447(7143), 465-468. 10.1038/nature05834.

Farr, T. G., Rosen, P. A., Caro, E., Crippen, R., Duren, R., Hens- ley, S., et al. 2007. The shuttle radar topography mission, Rev. Geophys., 45, 10.1029/2005RG000183.

Feakins, S. J., Wu, M. S., Ponton, C., Galy, V., \& West, A. J. 2018. Dual isotope evidence for sedimentary integration of plant wax biomarkers across an Andes-Amazon elevation transect. Geochimica et Cosmochimica Acta, 242, 64-81. 10.1016/j.gca.2018.09.007.Filizola, N., \& Guyot, J. L. 2009. Suspended sediment yields in the Amazon basin: an assessment using the Brazilian national data set. Hydrological Processes, 23, 3207-3215. 10.1002/hyp.7394.

Fricke, A. T., Nittrouer, C. A., Ogston, A. S., Nowacki, D. J., Asp, N. E., Souza Filho, P. W. M., \& da Silva, M. S. 2017. River tributaries as sediment sinks: Processes operating where the Tapajós and Xingu rivers meet the Amazon tidal river. Sedimentology, 64(6), 
1731-1753. 10.1111/sed.12372.

Garreaud, R. D., Vuille, M., Compagnucci, R., \& Marengo, J. 2009. Present-day South American climate. Palaeogeography, Palaeoclimatology, Palaeoecology, 281(3-4), 180195. 10.1016/j.palaeo.2007.10.032

Govin, A., Chiessi, C. M., Zabel, M., Sawakuchi, A. O., Heslop, D., Hörner, T., et al. 2014. Terrigenous input off northern South America driven by changes in Amazonian climate and the North Brazil Current retroflection during the last $250 \mathrm{ka}$. Climate of the Past, 10(2), 843-862. 10.5194/cp-10-843-2014.

Guyot, J. L., Jouanneau, J. M., Soares, L., Boaventura, G. R., Maillet, N., \& Lagane, C. 2007. Clay mineral composition of river sediments in the Amazon Basin. Catena, 71(2), 340356. 10.1016/j.catena.2007.02.002.

Häggi, C., Sawakuchi, A. O., Chiessi, C. M., Mulitza, S., Mollenhauer, G., Sawakuchi, H. O., et al. 2016. Origin, transport and deposition of leaf-wax biomarkers in the Amazon Basin and the adjacent Atlantic. Geochimica et Cosmochimica Acta, 192, 149-165. 10.1016/j.gca.2016.07.002.

Häggi, C., Chiessi, C. M., Merkel, U., Mulitza, S., Prange, M., Schulz, M., \& Schefuß, E. 2017. Response of the Amazon rainforest to late Pleistocene climate variability. Earth and Planetary Science Letters, 479, 50-59. 10.1016/j.epsl.2017.09.013.

Heckenberger, M., \& Neves, E. G. 2009. Amazonian archaeology. Annual Review of Anthropology, 38, 251-266. 10.1146/annurev-anthro-091908-164310.

van Hengstum, P. J., Donnelly, J. P., Fall, P. L., Toomey, M. R., Albury, N. A., \& Kakuk, B. 2016. The intertropical convergence zone modulates intense hurricane strikes on the western North Atlantic margin. Scientific reports, 6, 21728. 10.1038/srep21728.

Höppner, N., Lucassen, F., Chiessi, C. M., Sawakuchi, A. O., \& Kasemann, S. A. 2018. Holocene provenance shift of suspended particulate matter in the Amazon River basin. Quaternary Science Reviews, 190, 66-80. 10.1016/j.quascirev.2018.04.021.

Kanner, L. C., Burns, S. J., Cheng, H., Edwards, R. L., \& Vuille, M. 2013. High-resolution variability of the South American summer monsoon over the last seven millennia: 
Insights from a speleothem record from the central Peruvian Andes. Quaternary Science Reviews, 75, 1-10. 10.1016/j.quascirev.2013.05.008.

Konhauser, K. O., Fyfe, W. S., \& Kronberg, B. I. 1994. Multi-element chemistry of some Amazonian waters and soils. Chemical Geology, 111(1-4), 155-175. 10.1016/00092541(94)90088-4.

Laskar, J., Robutel, P., Joutel, F., Gastineau, M., Correia, A. C. M., \& Levrard, B. 2004. A long-term numerical solution for the insolation quantities of the Earth. Astronomy and Astrophysics, 428(261-285). 10.1051/0004-6361:20041335.

Latrubesse, E. M., Stevaux, J. C., \& Sinha, R. 2005. Tropical rivers. Geomorphology, 70(34), 187-206. 10.1016/j.geomorph.2005.02.005.

Lopes, A. V., Chiang, J. C. H., Thompson, S. A., \& Dracup, J. A. 2016. Trend and uncertainty in spatial-temporal patterns of hydrological droughts in the Amazon basin. Geophysical Research Letters, 43(7), 3307-3316. 10.1002/2016GL067738

Maezumi, S. Y., Alves, D., Robinson, M., de Souza, J. G., Levis, C., Barnett, R. L, et al. 2018. The legacy of 4,500 years of polyculture agroforestry in the eastern Amazon. Nature plants, 4, 540-547. 10.1038/s41477-018-0205-y.

Malaizé, B., Bertran, P., Carbonel, P., Bonnissent, D., Charlier, K., Galop, D., et al. 2011. Hurricanes and climate in the caribbean during the past 3700 years BP. Holocene, 21(6), 911-924. 10.1177/0959683611400198.

Marcott, S. A., Shakun, J. D., Clark, P. U., \& Mix, A. C. 2013. A Reconstruction of Regional and Global Temperature for the Past 11,300 Years. Science, 339(6124), 1198-1201. 10.1126/science.1228026.

Marengo, J. A. 2004. Interdecadal variability and trends of rainfall across the Amazon basin. Theoretical and Applied Climatology, 78(1-3), 79-96. 10.1007/s00704-004-0045-8

Marengo, J. A., Nobre, C. A., Tomasella, J., Cardoso, M. F., \& Oyama, M. D. 2008. Hydroclimatic and ecological behaviour of the drought of Amazonia in 2005. Philosophical Transactions of the Royal Society B: Biological Sciences, 363(1498), 1773-1778. 10.1098/rstb.2007.0015. 
Marengo, J. A., \& Espinoza, J. C. 2016. Extreme seasonal droughts and floods in Amazonia: Causes, trends and impacts. International Journal of Climatology, 36(3), 1033-1050. $10.1002 /$ joc. 4420

Masson, V., Vimeux, F., Jouzel, J., Morgan, V., Delmotte, M., Ciais, P., et al. 2000. Holocene climate variability in Antarctica based on 11 ice-core isotopic records. Quaternary Research, 54(3), 348-358. 10.1006/qres.2000.2172.

Meggers, B. J. 1994. Archeological evidence for the impact of mega-Niño events on Amazonia during the past two millennia. Climatic Change, 28(4), 321-338. 10.1007/BF01104077.

Miller, B. A., \& Schaetzl, R. J. 2012. Precision of soil particle size analysis using laser diffractometry. Soil Science Society of America Journal, 76(5), 1719-1727. 10.2136/sssaj2011.0303.

Nielsen, S. H. H., Koç, N., \& Crosta, X. 2004. Holocene climate in the Atlantic sector of the Southern Ocean: Controlled by insolation or oceanic circulation? Geology, 32(4), 317320. 10.1130/G20334.1.

Nogueira, C., Buckup, P. A., Menezes, N. A., Oyakawa, O. T., Kasecker, T. P., Neto, M. B. R. \& da Silva, J. M. C. 2010. Restricted-range fishes and the conservation of Brazilian freshwaters. PLoS ONE, 5(6), 1-10. 10.1371/journal.pone.0011390.

Panisset, J. S., Libonati, R., Gouveia, C. M. P., Machado-Silva, F., França, D. A., França, J. R. A. \& Peres, L. F. 2018. Contrasting patterns of the extreme drought episodes of 2005, 2010 and 2015 in the Amazon Basin. International Journal of Climatology, 38(2), 10961104. 10.1002/joc.5224.

Ponton, C., West, A. J., Feakins, S. J., \& Galy, V. 2014. Leaf wax biomarkers in transit record river catchment composition. Geophysical Research Letters, 41(18), 6420-6427. 10.1002/2014GL061328.

Pupim, F. N., Sawakuchi, A. O., Mineli, T. D. \& Nogueira, L. 2016. Evaluating isothermal thermoluminescence and thermally transferred optically stimulated luminescence for dating of Pleistocene sediments in Amazonia. Quaternary Geochronology, 36, 28-37. 
10.1016/j.quageo.2016.08.003.

Rosqvist, G. C., \& Schuber, P. 2003. Millennial-scale climate changes on south Georgia, southern ocean. Quaternary Research, 59(3), 470-475. 10.1016/S0033-5894(03)00036$\mathrm{X}$.

Sawakuchi, A. O., Hartmann, G. A., Sawakuchi, H. O., Pupim, F. N., Bertassoli, D. J., Parra, M., et al. 2015. The Volta Grande do Xingu: Reconstruction of past environments and forecasting of future scenarios of a unique Amazonian fluvial landscape. Scientific Drilling, 20. 10.5194/sd-20-21-2015.

Sawakuchi, A. O., Jain, M., Mineli, T. D., Nogueira, L., Bertassoli, D. J., Häggi, C., et al. 2018. Luminescence of quartz and feldspar fingerprints provenance and correlates with the source area denudation in the Amazon River basin. Earth and Planetary Science Letters, 492, 152-162. 10.1016/j.eps1.2018.04.006.

Schneider, T., Bischoff, T., \& Haug, G. H. 2014. Migrations and dynamics of the intertropical convergence zone. Nature, 513(7516), 45. 10.1038/nature13636.

Shevenell, A. E., Ingalls, A. E., Domack, E. W., \& Kelly, C. 2011. Holocene Southern Ocean surface temperature variability west of the Antarctic Peninsula. Nature, 470(7333), 250254. 10.1038/nature09751.

Sun, S., Schefuß, E., Mulitza, S., Chiessi, C. M., Sawakuchi, A. O., Zabel, M., et al. 2017. Origin and processing of terrestrial organic carbon in the Amazon system: Lignin phenols in river, shelf, and fan sediments. Biogeosciences, 14(9), 2495-2512. $10.5194 /$ bg-14-2495-2017.

Ustra, A., Mendonça, C.A., Leite, A., Jovane, L., \& Trindade, R.I.F. 2018. Quantitative interpretation of the magnetic susceptibility frequency dependence. Geophys. J. Int., 213, 805-814. 10.1093/gji/ggy007.

Wang, X., Lawrence Edwards, R., Auler, A. S., Cheng, H., Kong, K., Wang, Y., et al. 2017. Hydroclimate changes across the Amazon lowlands over the past 45,000 years. Nature, 541(7636), 204-207. 10.1038/nature20787.

Wittmann, H., von Blanckenburg, F., Maurice, L., Guyot, J. L., Filizola, N., \& Kubik, P. W. 
2011. Sediment production and delivery in the Amazon River basin quantified by in situproduced cosmogenic nuclides and recent river loads. Bulletin of the Geological Society of America, 123(5), 934-950. 10.1130/B30317.1

Wohl, E. E., \& Merritt, D. M. 2001. Bedrock Channel Morphology. Geological Society Of America Bulletin, 113(9), 1205-1212. 10.1130/0016-7606(2001)113<1205.

Zeng, N., Yoon, J. H., Marengo, J. A., Subramaniam, A., Nobre, C. A., Mariotti, A., \& Neelin, J. D. 2008. Causes and impacts of the 2005 Amazon drought. Environmental Research Letters, 3(1). 10.1088/1748-9326/3/1/014002.

Zhang, Y., Chiessi, C. M., Mulitza, S., Sawakuchi, A. O., Häggi, C., Zabel, M., et al. 2017. Different precipitation patterns across tropical South America during Heinrich and Dansgaard-Oeschger stadials. Quaternary Science Reviews, 177, 1-9. 10.1016/j.quascirev.2017.10.012.

\subsection{Supplementary Material}

The supplementary material for this article can be found in Appendix I. 


\section{THE FATE OF CARBON IN SEDIMENTS OF THE XINGU AND TAPAJÓS CLEARWATER RIVERS, EASTERN AMAZON}

Bertassoli Jr., D.J., Sawakuchi, A.O., Sawakuchi, H.O., Pupim, F.N., Hartmann, G.A., McGlue, M.M., Chiessi, C.M., Zabel, M., Schefuß, E., Pereira, T.S., Santos, R.A., Faustino, S.B., Oliveira, P.E., Bicudo, D.C.

\subsection{Abstract}

The Xingu and Tapajós rivers in the eastern Amazon are the largest clearwater systems of the Amazon basin. Both rivers have "fluvial rias" (i.e., lake-like channels) in their downstream reaches as they are naturally impounded by the Amazon mainstem. Fluvial rias are widespread in the Amazon landscape and most of the sedimentary load from the major clearwater and blackwater rivers is deposited in these channels. So far, little is known about the role of Amazon rias as a trap and reactor for organic sediments. In this study, we used organic and inorganic geochemistry, magnetic susceptibility, diatom, and pollen analyses in sediments (suspended, riverbed, and downcore) of the Xingu and Tapajós rias to investigate the effects of hydrologic variations on the carbon budget in these clearwater rivers over the Holocene. Ages of sediment deposition ( 100 to 5,500 years) were constrained by optically stimulated luminescence and radiocarbon. Major elements geochemistry and concentration of total organic carbon (TOC) indicate that seasonal hydrologic variations exert a strong influence on riverine productivity and on the input and preservation of organic matter in sediments. Stable carbon isotope data $\left(\delta^{13} \mathrm{C}\right.$ from -31.04 to $-27.49 \%$ ) and pollen analysis indicate that most of the carbon buried in rias is derived from forests. In the Xingu River, diatom analysis in bottom sediments revealed 65 infrageneric taxa that are mostly welladapted to slack oligotrophic and acidic waters. TOC values in sediment cores are similar to values measured in riverbed sediments and indicate suitable conditions for organic matter preservation in sediments of the Xingu and Tapajós rias at least since the mid-Holocene, with carbon burial rates varying from about $84 \mathrm{~g} \mathrm{~m}^{-2} \mathrm{yr}^{-1}$ to $169 \mathrm{~g} \mathrm{~m}^{-2} \mathrm{yr}^{-1}$. However, redoxsensitive elements in sediment core indicate alternation between anoxic/dysoxic and oxic conditions in the water-sediment interface that may be linked to abrupt changes in precipitation. The variation between anoxic/dysoxic and oxic conditions in the water-sediment interface controls organic matter mineralization and methanogenesis. Thus, such changes 
promoted by hydrological variations significantly affect the capacity of Amazon rias to act either as sources or sinks of carbon.

\subsection{Introduction}

Recent research has undermined the view of rivers as passive conveyors of organic matter, and demonstrates their role in the transport, modulation, and deposition of carbon (Aufdenkampe et al., 2011; Cole et al., 2007; Tranvik et al., 2009; Ward et al., 2015). Inland waters emit at least $0.8 \mathrm{Pg}$ of carbon per year (Cole et al., 2007; Tranvik et al. 2009). Approximately one fourth of it comes from rivers (Cole et al., 2007). The Amazonian rivers represent about $15 \%$ of the terrestrial gross primary production and $25 \%$ of the global rivers emissions of $\mathrm{CO}_{2}$ (Field, 1998; Richey et al., 2002). Most studies that have considered organic matter remineralization and carbon storage in the region have focused on the Amazon mainstem and its floodplains (Abril et al., 2014; Bouchez et al., 2010, 2012; Richey et al., 2002; Ward et al., 2015). However, the lack of geochemical data to constrain the role of major clearwater tributaries of the Amazon River as a source or sink of organic sediments limited the understanding of the carbon cycling dynamics across the terrestrial and aquatic environments of the Amazon basin.

The Xingu and Tapajós rivers represent the largest Amazon clearwater rivers, with mean annual discharges of 9,700 and 13,500 $\mathrm{m}^{3} \mathrm{~s}^{-1}$ (Latrubesse et al., 2005), respectively. They drain crystalline and sedimentary rocks of the Central Brazil shield and are characterized by relatively low concentrations of suspended sediments, slightly alkaline waters (Sioli, 1984), and high fluxes of methane to the atmosphere (Sawakuchi et al., 2014). Both rivers are naturally impounded by the Amazon mainstem, which give rise to broad downstream lake-like channels known as "fluvial rias" (Gourou, 1949; Archer, 2005). The Xingu and Tapajós rivers have strong seasonal variations, with mean monthly water discharges varying from approximately 1,000 to $20,000 \mathrm{~m}^{-3} \mathrm{~s}^{-1}$ in the Xingu River and 4,000 to $30,000 \mathrm{~m}^{-3} \mathrm{~s}^{-1}$ in the Tapajós River (ANA, 2016). The peak discharges of these clearwater rivers occurs from February to May. The Amazon River, however, has a mean monthly water discharge that varies from approximately $105,000 \mathrm{~m}^{-3} \mathrm{~s}^{-1}$ to $235,000 \mathrm{~m}^{-3} \mathrm{~s}^{-1}$, with peak discharge from April to July (ANA, 2016). The lag between the peak discharge of the Amazon River and its clearwater tributaries is responsible for strong backwater effects in the Xingu and Tapajós rivers (Meade et al., 1991). The sudden drop in water flow velocity and channel widening related to the hydraulic blockage and backwater effect by the Amazon 
mainstem prevent most of the Xingu and Tapajós suspended and bedload sediments from entering the Amazon River. These conditions turn rias into massive sinks for organic and inorganic sediments and natural reactors for carbon derived from the headwaters. Fluvial rias in the downstream section of the Xingu and Tapajós rivers reach up to $15 \mathrm{~km}$ width and around $150 \mathrm{~km}$ length. Hundreds of rias and paleo-rias occupy the Amazonian landscape and connect all clearwater and blackwater tributaries to the Amazon River, playing an important role for the transport and deposition of fine-grained sediments in the Amazon fluvial system. Thus, the accumulation of fine-grained sediments in rias has a strong effect on carbon processing and transport to the Amazon River and the Atlantic Ocean. To date, studies addressing Amazonian fluvial rias focus mainly on climatic and sediment deposition changes, without consensus about their genesis (Bertani et al., 2014; Keim et al., 1999; Sioli, 1984; Vital and Stattegger, 2000). The extant Amazon rias appear to have been formed after the Last Glacial Maximum (LGM, 23-19 ka) (Archer, 2005; Irion et al., 2011). The prevailing hypothesis suggests that the incised valleys formed during the low sea level phase of the LGM were flooded and accumulated sediments during the Holocene transgression (Archer, 2005; Irion et al., 2006, 2011). Sediment cores retrieved from the Tapajós Ria contain fine-grained sediments with 2.2 to $3.5 \%$ of total organic carbon and sedimentation rates reaching up to 6.5 $\mathrm{mm} \mathrm{yr}^{-1}$ (Irion, 2006). This reinforces the potential of rias as location of sediment deposition and carbon processing in the Amazon fluvial system.

Rias show sedimentary dynamics similar to that of lakes and reservoirs, which bury more than $200 \mathrm{Tg}$ of organic carbon annually (Dean and Gorham, 1998). Despite the widespread distribution in the Amazon and dominance of organic-rich sediments (Irion et al., 2011), rias are poorly studied with respect to their role as sink or source of carbon in the Amazon basin. According to Sawakuchi et al. (2014), methane fluxes in Amazon rivers account for $22-28 \%$ of the global river emissions of methane and the Amazon rias are hotspots of methane production. Rias also serve as analogues for carbon processing in artificial reservoirs like the recently build reservoirs of the Belo Monte hydropower plant in the Xingu River and future reservoirs planned for the Tapajós River (Winemiller et al., 2016). Clearwater Amazon rivers are the main target in the energy expansion plans of the Brazilian government (EPE/MME, 2007), which regards hydropower as inexpensive and clean energy, however, without consideration of impacts of river impoundment on Amazon ecosystems (Fearnside, 2014; Winemiller et al., 2016) and emission of greenhouse gases (Barros et al., 2011; de Faria et al., 2015). To assess the combined effect of carbon fluxes in Amazon rivers, it is imperative to fully understand carbon burial and emission rates in all main Amazon 28 
sedimentary environments. In this paper, we focus on carbon dynamics in the rias of the Xingu and Tapajós rivers. Geochemical, magnetic susceptibility, pollen, and diatom analyses combined with luminescence and radiocarbon dating are used to constrain the sources and fate of carbon in sediments of the Xingu and Tapajós rivers on millennial timescales. We integrated our data and results from previous literature to evaluate the origin and content of organic matter and to understand major controls affecting carbon burial in the Xingu and Tapajós rias.

\subsection{Material and Methods}

\subsubsection{Sediment sampling}

Sediment cores and samples of riverbed and suspended sediments were collected from Xingu, Tapajós and Amazon rivers are presented in Figure 1 and in Supplementary Material (Table S1). Suspended sediment samples were taken both during the dry and wet seasons from Xingu, Tapajós, and Amazon rivers in order to fully encompass variations in sediment composition related to hydrological changes. Suspended and riverbed sediment samples from the Amazon mainstem were collected upstream and downstream the Tapajós and Xingu rivers mouths (Figure 1) in order to evaluate the effect of input of sediments from the Xingu and Tapajós rivers on the Amazon River. Suspended sediment samples were collected through water pumped at approximately $60 \%$ of the water depth in the channel thalweg. For each sample, four liters of water were filtrated using cellulose acetate membranes (pore size of $0.45 \mu \mathrm{m}$ ). Riverbed sediments were collected using a Van Veen grab sampler. A total of 23 suspended sediment samples and 28 riverbed sediment samples were used in this study. 

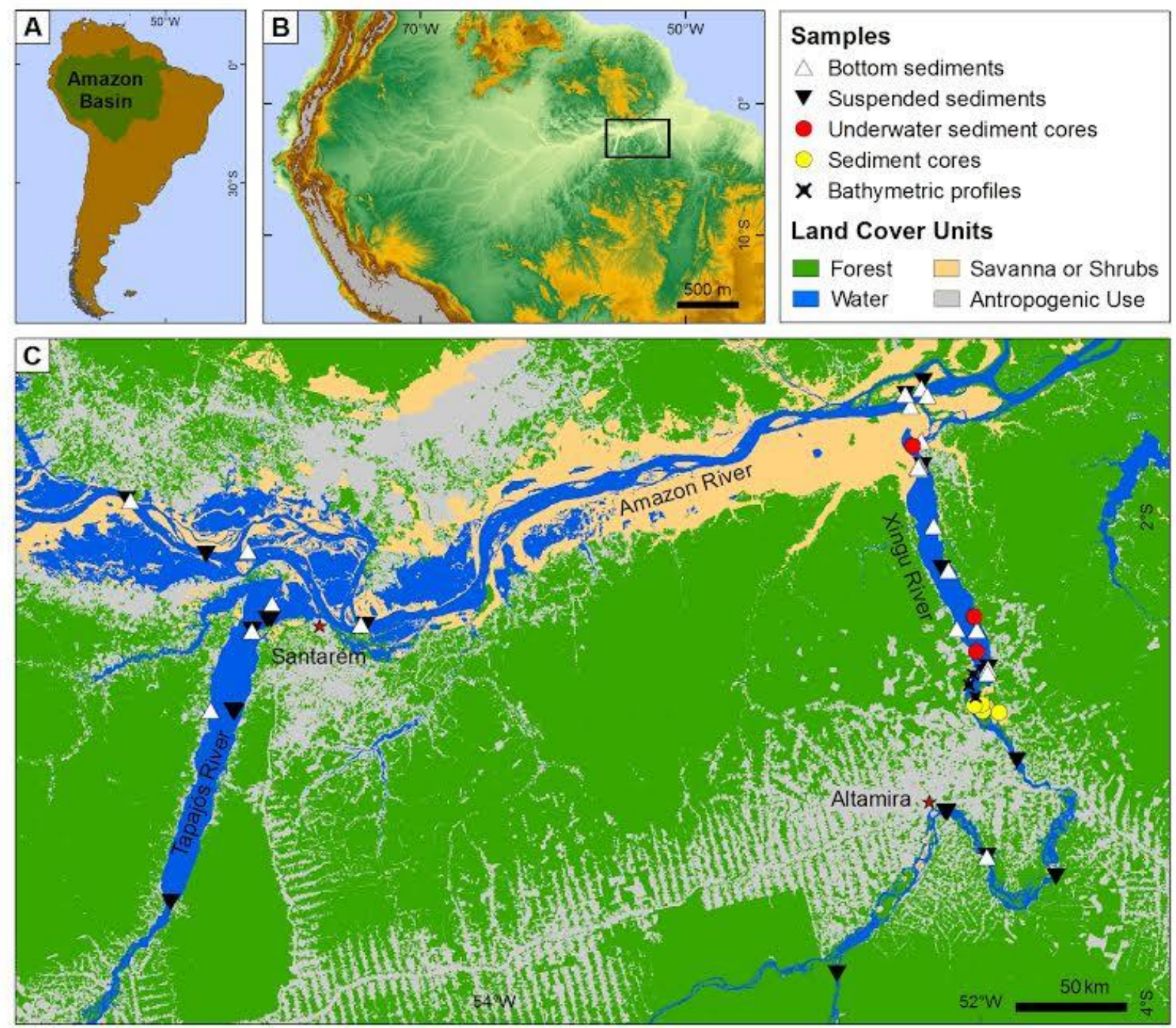

Figure 1 - Study area, location of sediment samples (suspended, riverbed and cores) and bathymetric profiles. In this work, underwater sediment cores were named "XC" and sediment cores from islands were named "EMB". Land-use map from Almeida et al. (2016).

Sediment cores of the Xingu Ria were collected from deeper portions of the lake-like channel covered by muddy sediments (named "XC") and from islands in the upstream section of the Xingu Ria (named "EMB"). The locations were selected based on water depth profiles and riverbed sediment sampling (further details in Sawakuchi et al., 2015). Underwater sediment cores from the Xingu Ria channel were retrieved by divers using PVC tubes of up to $6 \mathrm{~m}$ in length and percussion method (Sawakuchi et al., 2015). Three underwater sediment cores, characterized by dark gray to brown muds with thicknesses of $300 \mathrm{~cm}$ (XC02), $370 \mathrm{~cm}$ (XC03) and $470 \mathrm{~cm}$ (XC05), respectively, were retrieved from the Xingu Ria. Unconsolidated sediments from islands of the Xingu Ria head were collected using a piston-corer attached to a manual auger. Four sediment cores composed of fine to medium sands and muddy organic sediments were obtained from the islands: EMB13-07 $(555 \mathrm{~cm})$, EMB13-13 $(430 \mathrm{~cm})$, 
EMB13-17 $(250 \mathrm{~cm})$, and EMB13-21 $(345 \mathrm{~cm})$. Samples for luminescence dating were collected using opaque plastic tubes.

Bathymetric profiles were recorded along the upstream part of the Xingu Ria using sonar and GPS equipment. Samples collected with the Van Veen grab sampler were used to characterize riverbed sediments along bathymetric profiles. Water depth profiles and texture of riverbed sediments of the Xingu Ria are shown in Figure 2.
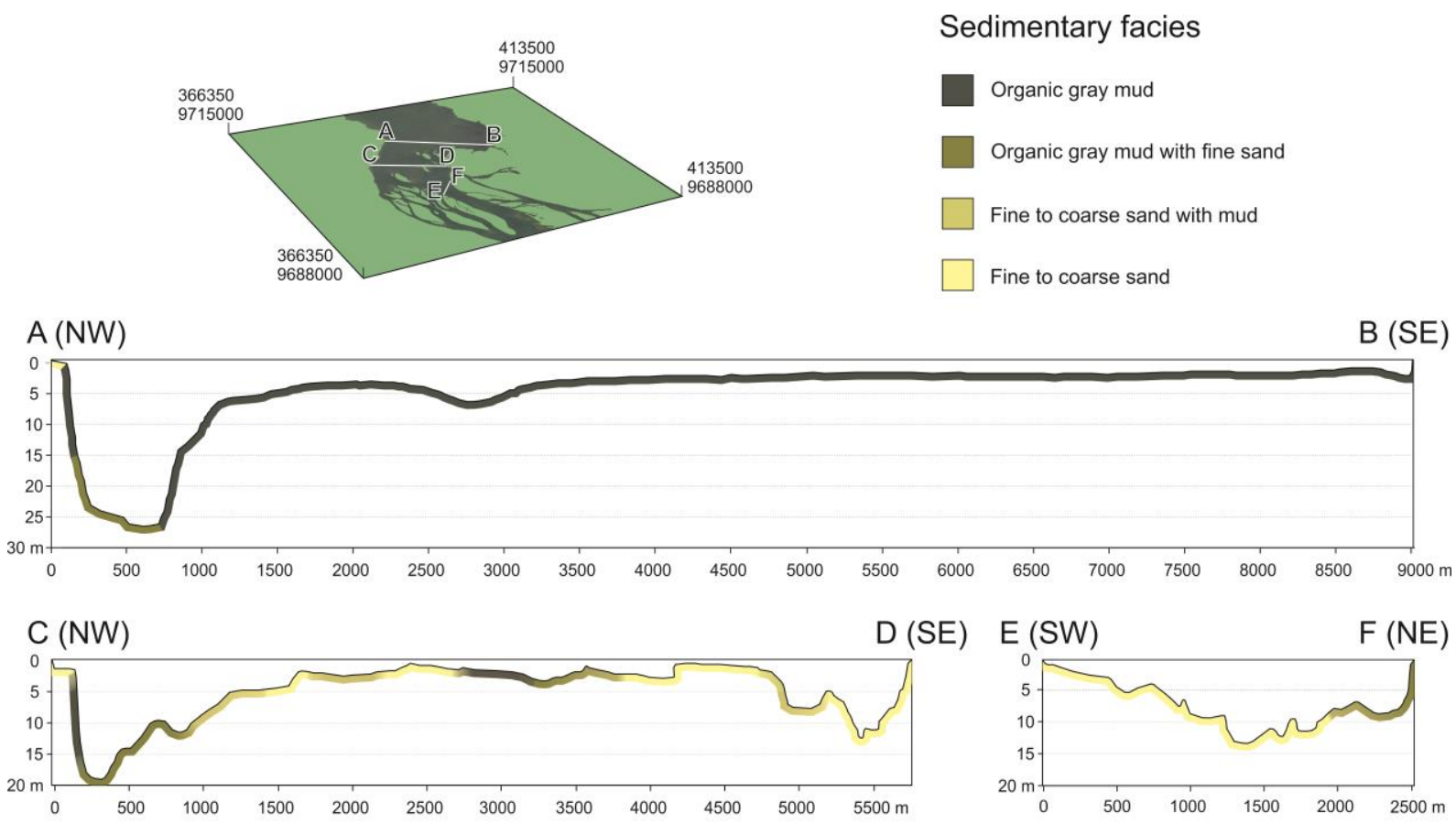

Figure 2 - Bathymetry and riverbed sediment texture in the upstream sector of the Xingu Ria.

\subsubsection{Organic and inorganic geochemistry of sediments}

Total organic carbon (TOC) content and its stable carbon isotope ratios $\left(\delta^{13} \mathrm{C}_{\text {org }}\right)$ were measured in 28 riverbed sediments samples at MARUM, University of Bremen. Sediments from the core XC05 were sampled at $2 \mathrm{~cm}$ intervals for total carbon coulometric and $\mathrm{x}$-ray fluorescence (XRF) analysis at the University of Kentucky.

Major elements (P, Ca, Fe, Mn, Al, Ti, K) concentrations were determined with an Agilent 720 inductively coupled plasma - optical emission spectrometer (ICP-OES) for 23 samples of suspended sediments and with a Bruker Tracer IV SD energy dispersive x-ray fluorescence (XRF) spectrometer for 13 riverbed sediments samples and 234 samples of the sediment core XC05. ICP-OES analysis of suspended sediments and XRF analysis of riverbed sediments were performed at MARUM, University of Bremen. For ICP-OES analysis, 
digestion of suspended material was performed with a MLS 1200 MEGA microwave system. For this purpose, $7 \mathrm{ml} \mathrm{HNO}_{3}$ (65\%), $0.5 \mathrm{ml} \mathrm{HF} \mathrm{(40 \% ),} 0.5 \mathrm{ml} \mathrm{HCl}(30 \%)$, and $0.5 \mathrm{ml} \mathrm{MilliQ}$ were added to about $50 \mathrm{mg}$ sample material (filter plus suspended material) previously placed into Teflon liners. All acids were of supra-pure quality. For XRF analysis, sediments were prepared by freeze drying, grinding by hand with an agate mortar and pestle, and sieving to $\sim 125 \mu \mathrm{m}$ prior to packing into inert sample boats sealed with an ultra-thin mylar window. Individual XRF scans for each sample were made through the mylar window over 90 seconds, in order to maximize signal-to-noise. Major elements (atomic numbers 11 through 30) were collected under a $\sim 9$ torr vacuum, by setting the XRF filter to $15 \mathrm{keV}$ and $35 \mu \mathrm{A}$. Trace elements (atomic numbers 20 through 51), were collected at $40 \mathrm{keV}$ and $15 \mu \mathrm{A}$ without a vacuum. Calibration of unknowns utilized Bruker proprietary software (S1CALPROCESS with TR2.cfz and MA1.cfz) and a reference catalogue of mudrock chemistry described in Rowe et al. (2012). Internal consistency of the XRF was verified by routine scanning of the SARM41 shale standard (Ring, 1989). The chief focus of our analysis was the major rockforming ( $\mathrm{Al}, \mathrm{Ca}, \mathrm{K}, \mathrm{Ti}, \mathrm{P})$ and redox-sensitive $(\mathrm{Mn}, \mathrm{Fe})$ elements. Inorganic chemistry data provide insights on mineralogy as well as depositional environments and hydrodynamic processes, especially when paired with organic carbon data (Sageman et al., 2003; Algeo and Rowe, 2012; Scott and Lyon, 2012).

TOC was determined using a LECO CS 200 CS-Analyzing System and an UIC Coulometrics Inc. Carbonate Coulometer (Engleman et al., 1985). The LECO method determines total carbon content through combustion of a powdered sample (Jarvie, 1991). Values of TOC were obtained by subtracting total inorganic carbon determined by the coulometer from total carbon. This method is routinely employed in paleoenvironmental analysis due to its accuracy and small sample size requirements (e.g., Böning et al., 2005; Jackson and Roof, 1992; Schulte et al., 2000). The precision of the analysis, based on analysis of internal standards and replicates, was typically better than $+0.15 \%$. The $\delta^{13} \mathrm{C}_{\text {org }}$ signature of de-carbonated samples was analyzed on a Finnigan MAT Delta plus coupled to a CE elemental analyzer. $\delta^{13} \mathrm{C}_{\text {org }}$ is reported using the delta notation relative to the Vienna Pee Dee Belemnite (VPDB). The uncertainty was less than $\pm 0.1 \%$.

Results were analyzed using R software (R Core Team, 2015). Major changes in hydrology and paleoenvironmental conditions were determined using constrained hierarchical cluster analysis of geochemistry and magnetic susceptibility data by the method of incremental sum of squares (CONISS, Grimm, 1987). 


\subsubsection{Magnetic susceptibility}

Magnetic susceptibility measurements were performed at the Paleomagnetic Laboratory (USPMag) of the Institute of Astronomy, Geophysics and Atmospheric Sciences of the University of São Paulo (IAG/USP). Magnetic susceptibility is used here as a complimentary method to identify significant variations in paleoenvironmental conditions or sediment composition in core XC05. A total of 194 paleomagnetic specimens were collected from the sediment core using cubic plastic boxes $\left(8 \mathrm{~cm}^{3}\right)$ placed side-by-side throughout the core. Low-field magnetic susceptibility of individual specimen was measured using a Kappabridge MFK1-FA system (AGICO Ltd). Two different frequencies (976 and 15616 Hz) were used in a $200 \mathrm{Am}^{-1}$ field at room temperature (Dearing et al., 1996). All data were mass normalized due to the irregular sample mass inside cubic boxes.

\subsubsection{Pollen and diatom analyses}

Riverbed samples were subsampled for pollen analyses (Supplementary Material, Table S1). Samples were processed for extraction of pollen grains using the protocol established by Colinvaux et al. (1999). The analyses were performed in the Institute of Geosciences of the University of São Paulo (IGc/USP) under a microscope with magnification of 600x. A minimum of 300 terrestrial pollen grains were counted per sample. Aquatic taxa and spores are not included in the sum of pollen assemblage. The pollen grains and spores were identified using the pollen reference collection of the University of São Paulo and other published reference materials (Colinvaux et al., 1999; Erdtman, 1952; Roubik and Moreno, 1991). The raw pollen count data were entered into the Tilia software (Grimm, 2011), in order to calculate the taxa percentages and concentrations.

Riverbed and sediment core XC05 were subsampled for diatom analyses. Diatom analysis followed standard procedures discussed by Battarbee et al. (2001). Slides were mounted with Naphrax ${ }^{\circledR}$ as medium. Optical observations and counts were conducted at a magnification of 1000x with a Zeiss Axioskop 2 plus microscope. At least 400 valves were counted per slide. Taxonomy and nomenclature followed published literature sources (e.g. Round et al., 1990; Rumrich et al., 2000, Krammer, 2000, Metzeltin and Lange-Bertalot, 2007) and the on-line catalogue of valid names (California Academy of Sciences, 2011). 


\subsection{5 $\mathrm{CH}_{4}$ and $\mathrm{CO}_{2}$ in sediment pore waters}

Sediment core XC05 was sub-sampled in field on the same day of collection for the assessment of dissolved methane and carbon dioxide concentrations in pore waters. Aliquots of $5 \mathrm{ml}$ of wet sediment were collected with an open-ended $5 \mathrm{ml}$ polypropylene syringe after carefully drilling holes at $10 \mathrm{~cm}$ intervals. Immediately after collection, the aliquots were injected into a $120 \mathrm{ml}$ vial containing $10 \mathrm{ml}$ of $\mathrm{NaOH}$ (5\%), capped with butyl rubber stoppers and sealed with aluminum crimps. Control standards of ambient air were collected during sampling for corrections. In the Center for Nuclear Energy in Agriculture of the University of São Paulo (CENA/USP), samples were shaken for headspace equilibration and $60 \mathrm{ml}$ of gas sample was retrieved from vials headspace using a $60 \mathrm{ml}$ syringe and analyzed by Cavity Ring Down Spectroscopy using a Picarro G2201-i device. Samples were slowly injected following the pump flow, taking care not to change the internal pressure, which can be monitored by the analyzer. The $60 \mathrm{ml}$ analyzes took approximately 3 minutes to pass through the analyzer giving a steady measurement for roughly 40 seconds that was checked with three standard gas mixtures for concentration and carbon isotope composition of $\mathrm{CH}_{4}$. Reproducibility between replicates presented a variation of the standard deviation $>0.5 \%$ for concentration and $>0.9 \%$ for $\delta^{13} \mathrm{C}_{\mathrm{CH} 4}$. Readings of concentration (ppm) and $\delta^{13} \mathrm{C}_{\mathrm{CH} 4}(\%$ ) by the analyzer were slightly different than the standard reference values. Thus, sample results were corrected according to a standard calibration curve.

\subsubsection{Optically stimulated luminescence and radiocarbon datings}

Optically stimulated luminescence (OSL) dating was carried out in fine silt or sand quartz aliquots from cores $\mathrm{XC02}, \mathrm{XC03}$ and $\mathrm{XC05}$ in the Luminescence and Gamma Spectrometry Laboratory of the IGc/USP. Quartz aliquots for luminescence measurements were prepared under subdued red light. Wet sieving and settling procedures were used to isolate the $4-11$ or $180-250 \mu \mathrm{m}$ grain sizes. The target grain size fractions were submitted to oxygen peroxide $\left(\mathrm{H}_{2} \mathrm{O}_{2}\right)$ and hydrochloric $(\mathrm{HCl} 10 \%)$ treatments to remove organic matter and carbonates, respectively. Heavy liquid separation of quartz sand grains was performed using lithium metatungstate solution at densities of 2.75 and $2.62 \mathrm{~g} \mathrm{~cm}^{-3}$ to remove heavy minerals and feldspar grains, respectively. Concentrates of quartz sand grains were etched with hydrofluoric acid (HF 38\%) for $40 \mathrm{~min}$ in order to remove the outer rind of quartz grains damaged by alpha particles and remnant feldspar grains. Luminescence measurements were 
performed in two automated Risø OSL/TL reader model DA-20 equipped with blue (470 nm) and infrared $(870 \mathrm{~nm})$ LEDs for light stimulation, Hoya U-340 filter for light detection in the ultraviolet band and built-in beta radiation sources $\left({ }^{90} \mathrm{Sr} /{ }^{90} \mathrm{Y}\right)$ delivering dose rates of 0.088 and $0.135 \mathrm{~Gy} \mathrm{~s}^{-1}$ (for aluminum discs). Equivalent doses were determined through the singlealiquot regenerative dose protocol (Murray and Wintle, 2000). For fine silt, a mean a-value of 0.04 was considered for calculation of alpha dose rate in quartz. Tests with infrared stimulation indicated absence of feldspar in the fine silt concentrates. A dose recovery test was performed to set up the luminescence measurements protocol to the studied samples batch. Samples equivalent doses were calculated through the Central Age Model (Galbraith et al., 1999). The concentrations of $\mathrm{K},{ }^{238} \mathrm{U}$ and ${ }^{232} \mathrm{Th}$ for dose rate calculations were determined using high resolution gamma spectrometry with a high purity germanium detector (relative efficiency of $55 \%$ and energy resolution of $2.1 \mathrm{KeV}$ ) encased in an ultralow background shield. Samples were packed in sealed plastic containers and stored for at least 28 days for radon equilibration before gamma spectrometry. Radiation dose rates were calculated using conversion factors outlined by Guérin et al. (2011). Radiation dose rates were corrected for water saturation (water weight/dry sample weight). Cosmic dose rates were calculated through samples latitude, longitude, elevation and burial depth, according to Prescott and Hutton (1994).

Accelerator mass spectrometry (AMS) radiocarbon $\left({ }^{14} \mathrm{C}\right)$ dating was performed on leaves and charcoal fragments retrieved from the sediment cores. Samples were treated in the Radiocarbon Laboratory of the Illinois State Geological Survey and submitted to the Keck Carbon Cycle AMS Laboratory of the University of California-Irvine for AMS ${ }^{14} \mathrm{C}$ analysis. The ${ }^{14} \mathrm{C}$ dates were calibrated using the program Calib 7.0 and the calibration curve IntCal 13 (Stuiver and Reimer, 1993; Reimer et al., 2013).

\subsection{Results}

\subsubsection{Geochemistry of suspended and riverbed sediments}

Geochemical results are summarized in Tables 1 and 2 (discretized dataset in Supplementary Material, Table S1). Strong variations in suspended sediment composition were identified between wet and dry seasons in the Xingu, Tapajós, and Amazon rivers (Table 1, Figure 3). Seasonal changes in suspended sediments of the Xingu and Tapajós rivers include the increase in the relative amount of $\mathrm{P}$ in sediments of the dry season, which is 
directly related to primary productivity (Dean and Gorham, 1998; Engstrom and Wright Jr, 1984). The P/Ti ratio is an effective proxy to evaluate the sedimentation of phosphorous regardless of terrigenous input and it avoids dilution effects caused by changes in sedimentation rate (Filippelli et al., 2003; Latimer and Filippelli, 2002). Average P/Ti ratios in the Xingu River vary from 0.66 in the wet season to 4.20 in the dry season. Seasonal changes in $\mathrm{P}$ concentration have lower amplitudes in the Tapajós River, with the P/Ti ratio shifting from 0.75 to 0.94 from the wet to the dry seasons, respectively. The Fe/K ratio is a useful indicator of mineralogical stability, since the most stable rock-forming minerals have lower $\mathrm{Fe} / \mathrm{K}$ ratios (K-feldspar, muscovite, and quartz) and unstable minerals tend to be richer in iron content (Armstrong-Altrin and Machain-Castillo, 2016; Herron, 1988). Fe/K ratios increase during the wet season both in the Xingu and Tapajós rivers, with relatively little variation in the Amazon River (Table 3). In the Xingu River, Ca concentrations increase from 0.09 to 0.35 $\mathrm{mg}^{-1}$ and $\mathrm{P}$ concentration from 0.03 to $0.71 \mathrm{mg} \mathrm{l}^{-1}$ between the wet and dry season. $\mathrm{Fe}$ concentrations shift from 1.11 to $2.56 \mathrm{mg} \mathrm{l}^{-1}$ from the wet to the dry season. The inverse pattern is observed in the Amazon River, with $\mathrm{Ca}, \mathrm{P}$, and Fe concentrations decreasing in the dry season (Table 1, Figure 3). In the Tapajós River, these shifts between wet and dry seasons have lower amplitude, with Ca concentration varying from 0.07 to $0.13 \mathrm{mg}^{-1}$, $\mathrm{P}$ varying from 0.03 to $0.05 \mathrm{mg}^{-1}$ and $\mathrm{Fe}$ varying from 0.99 to $0.76 \mathrm{mg} \mathrm{l}^{-1}$.
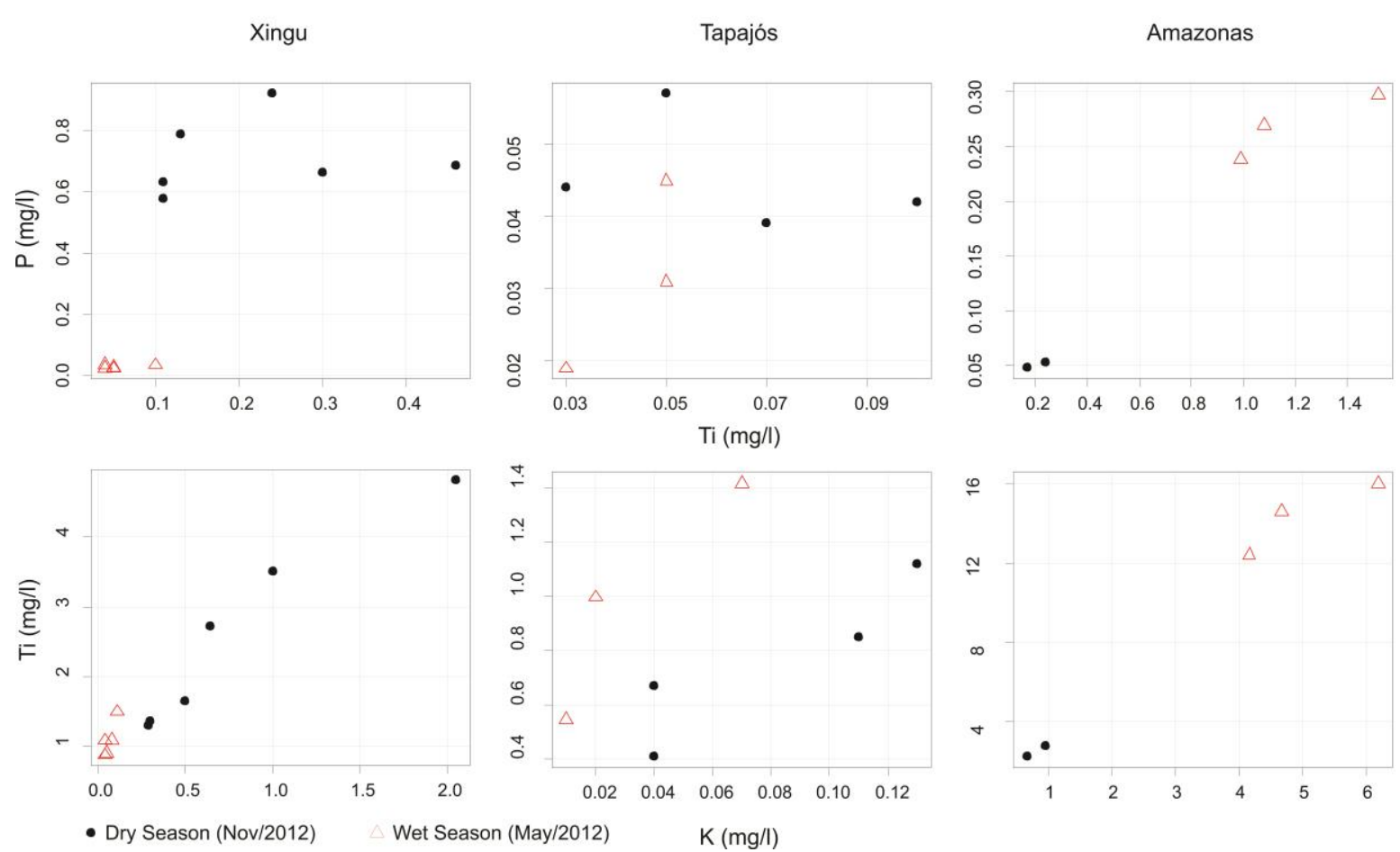

Figure 3 - Scatterplots comparing P, Ti and K concentrations in suspended sediments collected in the Xingu, Tapajós and Amazon rivers during the wet and dry seasons. 
Table 1 - Variation of major elements concentrations in suspended sediments of the Xingu, Tapajós and Amazon rivers during the wet and dry seasons. Data of individual samples are presented in Table S1 of the Supplementary Material.

\begin{tabular}{|c|c|c|c|c|c|c|c|c|c|c|}
\hline River & Season & $\mathbf{n}$ & $\begin{array}{l}\mathrm{Mg} \\
(\mathrm{mg} / \mathrm{l})\end{array}$ & $\begin{array}{l}\mathrm{Al} \\
(\mathrm{mg} / \mathrm{l})\end{array}$ & $\begin{array}{l}\mathrm{K} \\
(\mathrm{mg} / \mathrm{l}) \\
\end{array}$ & $\begin{array}{l}\mathrm{Ca} \\
(\mathrm{mg} / \mathrm{l})\end{array}$ & $\begin{array}{l}\mathrm{Ti} \\
(\mathrm{mg} / \mathrm{l})\end{array}$ & $\begin{array}{l}\mathrm{Mn} \\
(\mathrm{mg} / \mathrm{l})\end{array}$ & $\begin{array}{l}\mathrm{Fe} \\
(\mathrm{mg} / \mathrm{l})\end{array}$ & $\begin{array}{l}\mathbf{P} \\
(\mathrm{mg} / \mathrm{l})\end{array}$ \\
\hline \multirow[t]{2}{*}{ Xingu } & dry & 6 & $\begin{array}{l}0.30 \pm \\
0.102\end{array}$ & $\begin{array}{l}6.31 \pm \\
1.205\end{array}$ & $\begin{array}{l}0.80 \pm \\
0.272\end{array}$ & $\begin{array}{l}0.35 \pm \\
0.068\end{array}$ & $\begin{array}{l}0.22 \pm \\
0.057\end{array}$ & $\begin{array}{l}0.19 \pm \\
0.022\end{array}$ & $\begin{array}{l}2.56 \pm \\
0.572\end{array}$ & $\begin{array}{l}0.71 \pm \\
0.051\end{array}$ \\
\hline & wet & 5 & $\begin{array}{l}0.07 \pm \\
0.009\end{array}$ & $\begin{array}{l}1.72 \pm \\
0.283\end{array}$ & $\begin{array}{l}0.06 \pm \\
0.014\end{array}$ & $\begin{array}{l}0.09 \pm \\
0.015\end{array}$ & $\begin{array}{l}0.05 \pm \\
0.011\end{array}$ & $\begin{array}{l}0.05 \pm \\
0.006\end{array}$ & $\begin{array}{l}1.11 \pm \\
0.110\end{array}$ & $\begin{array}{l}0.03 \pm \\
0.003\end{array}$ \\
\hline \multirow[t]{2}{*}{ Tapajós } & dry & 4 & $\begin{array}{l}0.09 \pm \\
0.023\end{array}$ & $\begin{array}{l}2.37 \pm \\
0.650\end{array}$ & $\begin{array}{l}0.08 \pm \\
0.023\end{array}$ & $\begin{array}{l}0.13 \pm \\
0.027\end{array}$ & $\begin{array}{l}0.06 \pm \\
0.015\end{array}$ & $\begin{array}{l}0.12 \pm \\
0.23\end{array}$ & $\begin{array}{l}0.76 \pm \\
0.150\end{array}$ & $\begin{array}{l}0.05 \\
0.004\end{array}$ \\
\hline & wet & 3 & $\begin{array}{l}0.05 \pm \\
0.006\end{array}$ & $\begin{array}{l}1.68 \pm \\
0.350\end{array}$ & $\begin{array}{l}0.03 \pm \\
0.019\end{array}$ & $\begin{array}{l}0.07 \pm \\
0.027\end{array}$ & $\begin{array}{l}0.04 \pm \\
0.007\end{array}$ & $\begin{array}{l}0.03 \pm \\
0.006\end{array}$ & $\begin{array}{l}0.99 \pm \\
0.251\end{array}$ & $\begin{array}{l}0.03 \pm \\
0.008\end{array}$ \\
\hline \multirow[t]{2}{*}{ Amazon } & dry & 2 & $\begin{array}{l}0.46 \pm \\
0.055\end{array}$ & $\begin{array}{l}5.47 \pm \\
0.737\end{array}$ & $\begin{array}{l}0.81 \pm \\
0.140\end{array}$ & $\begin{array}{l}0.38 \\
0.035\end{array}$ & $\begin{array}{l}0.21 \pm \\
0.032\end{array}$ & $\begin{array}{l}0.04 \pm \\
0.005\end{array}$ & $\begin{array}{l}2.50 \pm \\
0.266\end{array}$ & $\begin{array}{l}0.05 \pm \\
0.002\end{array}$ \\
\hline & wet & 3 & $\begin{array}{l}2.24 \pm \\
0.269\end{array}$ & $\begin{array}{l}23.43 \pm \\
2.122\end{array}$ & $\begin{array}{l}5.01 \pm \\
0.613\end{array}$ & $\begin{array}{l}1.63 \pm \\
0.195\end{array}$ & $\begin{array}{l}1.19 \pm \\
0.164\end{array}$ & $\begin{array}{l}0.18 \pm \\
0.027\end{array}$ & $\begin{array}{l}14.40 \pm \\
1.051\end{array}$ & $\begin{array}{l}0.27 \pm \\
0.017\end{array}$ \\
\hline
\end{tabular}

Table 2 - Summary of major elements concentrations $(\mathrm{mg} / \mathrm{g})$, TOC and $\delta 13 \mathrm{C}_{\text {org }}$ of bulk organic matter in bottom sediments of the Xingu, Tapajós and Amazon rivers. Data of individual samples are presented in Table S1 of the Supplementary Material.

\begin{tabular}{llll}
\hline River & Xingu & Tapajós & Amazon \\
\hline $\mathbf{n}$ & 5 & 2 & 7 \\
$\mathbf{M g}(\mathbf{m g} / \mathbf{k g})$ & $1547 \pm 737$ & 5803 & $6009 \pm 180$ \\
$\mathbf{A l}(\mathbf{m g} / \mathbf{k g})$ & $75685 \pm 7649$ & $54944 \pm 20699$ & $70821 \pm 2270$ \\
$\mathbf{K}(\mathbf{m g} / \mathbf{k g})$ & $7342 \pm 1577$ & $8772 \pm 7754$ & $15204 \pm 418$ \\
$\mathbf{C a}(\mathbf{m g} / \mathbf{k g})$ & $3195 \pm 608$ & $3592 \pm 1904$ & $5987 \pm 222$ \\
$\mathbf{T i}(\mathbf{m g} / \mathbf{k g})$ & $3119 \pm 425$ & $3111 \pm 1642$ & $4366 \pm 67$ \\
$\mathbf{M n}(\mathbf{m g} / \mathbf{k g})$ & $330 \pm 99$ & $226 \pm 183$ & $438 \pm 51$ \\
$\mathbf{F e}(\mathbf{m g} / \mathbf{k g})$ & $26999 \pm 7462$ & $16367 \pm 13823$ & $25948 \pm 1702$ \\
$\mathbf{S i}(\mathbf{m g} / \mathbf{k g})$ & $196160 \pm 13454$ & $228105 \pm 1280$ & $221458 \pm 4768$ \\
$\mathbf{T O C}(\%)$ & $2.25 \pm 0.582$ & $0.2 \pm$ & $0.59 \pm 0.068$ \\
$\boldsymbol{\delta} \mathbf{1 3 C o r g}(\%)$ & $-28.64 \pm 0.288$ & - & $-28.02 \pm 0.201$ \\
\hline
\end{tabular}

Table 3 - Variation of elemental ratios in suspended sediments of the Xingu, Tapajós and Amazon rivers during the wet and dry seasons.

\begin{tabular}{lllllllllllll}
\hline River & Season & $\mathbf{n}$ & $\mathbf{F e} / \mathbf{K}$ & $\mathbf{P} / \mathbf{K}$ & $\mathbf{T i} / \mathbf{C a}$ & $\mathbf{M n} / \mathbf{K}$ & $\mathbf{P} / \mathbf{M g}$ & $\mathbf{F e} / \mathbf{C a}$ & $\mathbf{P} / \mathbf{T i}$ & $\mathbf{F e} / \mathbf{M n}$ & $\mathbf{T i} / \mathbf{A l}$ & $\mathbf{A l} / \mathbf{C a}$ \\
\hline Xingu & dry & 6 & 3.74 & 1.35 & 0.61 & 0.35 & 3.45 & 7.24 & 4.20 & 13.36 & 0.034 & 18.37 \\
& wet & 5 & 19.15 & 0.58 & 0.59 & 0.93 & 0.45 & 12.54 & 0.66 & 24.67 & 0.031 & 19.01 \\
\multirow{2}{*}{ Tapajós } & dry & 4 & 10.84 & 0.80 & 0.50 & 2.29 & 0.63 & 6.26 & 0.94 & 7.55 & 0.026 & 19.32 \\
& wet & 3 & 41.76 & 1.36 & 0.76 & 1.36 & 0.62 & 16.86 & 0.75 & 32.11 & 0.025 & 29.75 \\
\multirow{4}{*}{ Amazonas } & dry & 2 & 3.12 & 0.06 & 0.54 & 0.04 & 0.11 & 6.65 & 0.25 & 71.67 & 0.038 & 14.52 \\
& wet & 3 & 2.91 & 0.05 & 0.73 & 0.03 & 0.12 & 8.93 & 0.23 & 83.52 & 0.051 & 14.47 \\
\hline
\end{tabular}




\subsubsection{Pollen and diatoms in riverbed and core sediments}

In total, 45 pollen taxa were identified in riverbed sediments of the Xingu Ria (Supplementary Material, Figure S1 to S4). The vegetation represented by pollen retrieved from riverbed sediments has great diversity and high percentages of forest elements. Arboreal taxa encountered in the samples include Acalypha, Alchornea, Annacardiaceae, Apocynaceae, Arecaceae, Attalea, Bignoniaceae, Cecropia, Combretum, Dalbergia, Didymopanax, Euterpe, Fabacea, Genipa, Machaerium, Mauritia, Mauritiella, Matayba, Melastomataceae, Mimosa, Myrtaceae, Palmae, Psidium, Psychotria, Sapium, Spondias, Sterculiaceae, Stigmaphyllon, Talisia and Zygia. Terrestrial herbaceous elements are represented by Alternanthera, Asteraceae, Bambusa, Begonia, Caesaria, Lamiaceae, Phyllanthus, Pilea, Poaceae, Polygonaceae and Symmeria. Sagitaria, Cyperaceae, Alismataceae represent taxa of aquatic herbs. Spores identified in the analysis include Polypodiaceae, trilete and Monolete. The palynologic data indicate that riverbed sediments of the Xingu Ria record the input of sediments from areas where the predominant vegetation type is forest (Supplementary Material, Figure S5).

Regarding the diatoms, a total of 65 infrageneric taxa were identified in riverbed sediments of the Xingu Ria. Eunotia and Gomphonema were the most represented genera regarding species number (24.6\% of total species), followed by genus Aulacoseira (9.2\%) (Supplementary Material, Figure S6). Eunotia species are mostly acidophilic, oligotrophic, and typified by a dominant periphytic habitat (Van Dam et al., 1994; Hamilton and Siver, 2010; Moro and Fürstenberger, 1997; Round et al., 1990). Due to the secretion of mucilage by the apical pore fields, Gomphonema is a common genus in periphytic algal communities, being well represented in richness and density (Tremarin et al., 2009). Aulacoseira is a common planktonic genus inhabiting lacustrine and running freshwaters, developing in various trophic conditions (Denys et al., 2003; Zalat and Vildary 2007). Ecological information at species level is required to use this genus as indicator of water quality (Bicudo et al., 2016).

Diatoms presented well-preserved frustules throughout the core. Assemblages from the core XC05 base showed little variation among genera, and besides the planktonic genus Aulacoseira, comprised benthic and periphytic genera that require surfaces for developing (e.g., Eunotia, Pinnularia and Surirella), suggesting a water column under acidic and oligotrophic conditions with high light penetration. Genera Surirella, Diploneis, Aulacoseira, 
Placoneis, Gomphonema, Encyonema and Eunotia were observed throughout the core, suggesting a relatively uniform slack water environment.

\subsubsection{Chronology, magnetic and geochemistry data of sediment cores}

Sediments of the three studied underwater cores (XC02, XC03 and XC05) are composed of dark grey to brown organic-rich muddy sediments. As highlighted in Figure 2, these sediments are similar to the modern surface sediments that accumulate in most of the rias. Samples from the top and bottom of sediment cores XC02 (10-293 cm), XC03 (10-363 $\mathrm{cm})$ and XC05 $(45-440 \mathrm{~cm})$ were collected for OSL dating. The luminescence ages of cores XC02, XC03 and XC05 ranged from 118 \pm 81 to 4,086 \pm 159 years (Table 4), suggesting that the Xingu Ria is a slack water environment acting as trap of fine-grained sediments at least since the middle Holocene. XC02 sediments showed ages from 2,503 \pm 462 to $3,295 \pm 542$ years. XC03 and XC05 sediments cover periods from $118 \pm 81$ to $1,251 \pm 211$ years, and from $3,025 \pm 185$ to $4,086 \pm 159$ years, respectively. Sediment depth profiles described in the islands of the head of the Xingu Ria (EMB13-07, EMB13-13 and EMB13-17) show dark grey organic-rich sediments interlayered with sands and light gray floodplain sediments (Figure 4). Radiocarbon ages obtained in the dark grey muds, which likely represent buried ria sediments, varied from 141-267 to 5,479-5,580 cal years BP (Table 5, Figure 4).

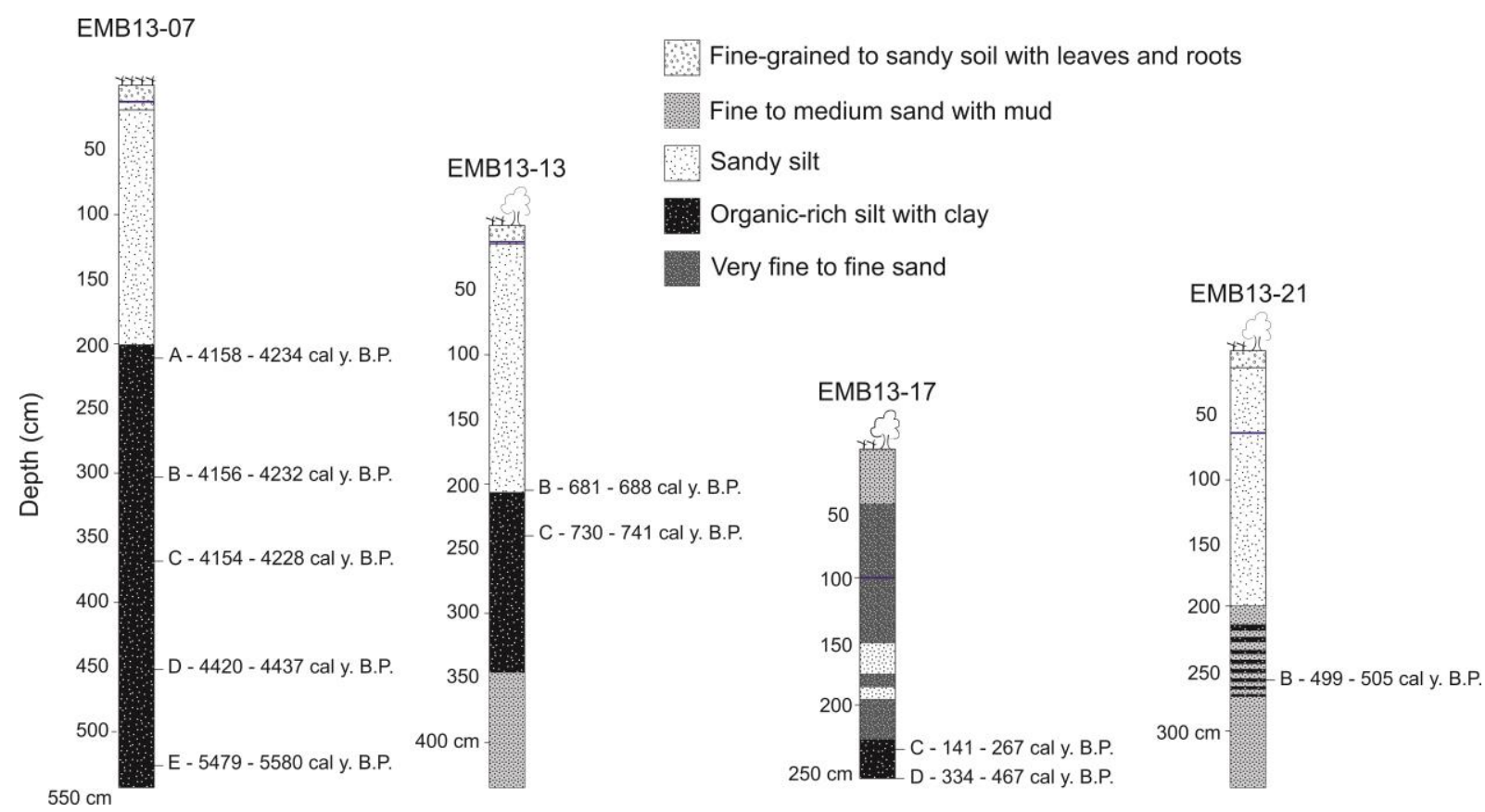

Figure 4 - Radiocarbon ages in sediment depth profiles of stabilized bar of the Xingu Ria head. Ria sediments are represented by organic-rich muds buried by organic-poor floodplain sediments. 
Table 4 - Radionuclides concentrations, radiation dose rates, equivalent doses and luminescence ages of sediment samples retrieved from cores XC02, XC03 and XC05.

\begin{tabular}{|c|c|c|c|c|c|c|c|c|}
\hline Sample & $\begin{array}{l}\begin{array}{l}\text { Depth } \\
\text { (cm) }\end{array} \\
\end{array}$ & $\begin{array}{l}\mathrm{U} \\
(\mathrm{ppm})\end{array}$ & $\begin{array}{l}\text { Th } \\
\text { (ppm) }\end{array}$ & $\begin{array}{l}K \\
(\%) \\
\end{array}$ & $\begin{array}{l}\text { Cosmic dose } \\
\text { rate }(\mathrm{Gy} / \mathrm{ka})\end{array}$ & $\begin{array}{l}\text { Total dose } \\
\text { rate }(\mathrm{Gy} / \mathrm{ka})\end{array}$ & $\begin{array}{l}\text { Equivalent } \\
\text { dose (Gy) }\end{array}$ & $\begin{array}{l}\begin{array}{l}\text { Age } \\
\text { (years) }\end{array} \\
\end{array}$ \\
\hline XC02-10 & 10 & $\begin{array}{l}5.35 \quad \pm \\
2.66 \mathrm{E}-1\end{array}$ & $\begin{array}{l}1.50 \quad \pm \\
8.87 \mathrm{E}-1\end{array}$ & $\begin{array}{l}0.67 \quad \pm \\
0.06\end{array}$ & $0.19 \pm 0.01$ & $1.72 \pm 0.29$ & $4.3 \pm 0.3$ & $\begin{array}{l}2503 \pm \\
462\end{array}$ \\
\hline XC02-293 & 293 & $\begin{array}{l}4.54 \quad \pm \\
2.12 \mathrm{E}-1\end{array}$ & $\begin{array}{l}15.58 \pm \\
8.30 \mathrm{E}-1\end{array}$ & $\begin{array}{l}0.67 \\
0.05\end{array}$ & $0.13 \pm 0.01$ & $1.7 \pm 0.28$ & $5.6 \pm 0.1$ & $\begin{array}{l}3295 \pm \\
542\end{array}$ \\
\hline XC03-10 & 10 & $\begin{array}{l}3.70 \quad \pm \\
1.87 \mathrm{E}-1\end{array}$ & $\begin{array}{l}7.66 \quad \pm \\
5.10 \mathrm{E}-1\end{array}$ & $\begin{array}{l}1.13 \pm \\
0.06\end{array}$ & $0.19 \pm 0.02$ & $2.55 \pm 0.41$ & $0.3 \pm 0.2$ & $\begin{array}{l}118 \pm \\
81\end{array}$ \\
\hline $\mathrm{XC03-363}$ & 363 & $\begin{array}{l}3.19 \pm \\
1.67 \mathrm{E}-1\end{array}$ & $\begin{array}{l}6.48 \quad \pm \\
4.55 \mathrm{E}-1\end{array}$ & $\begin{array}{l}1.14 \pm \\
0.06\end{array}$ & $0.12 \pm 0.01$ & $2.48 \pm 0.41$ & $3.1 \pm 0.1$ & $\begin{array}{l}1251 \pm \\
211\end{array}$ \\
\hline XC05-45 & 45 & $\begin{array}{l}4.53 \pm \\
1.69 \mathrm{E}-1\end{array}$ & $\begin{array}{l}19.95 \pm \\
7.64 \mathrm{E}-1\end{array}$ & $\begin{array}{l}0.7 \\
0.04\end{array}$ & $0.08 \pm 0.01$ & $2.05 \pm 0.08$ & $6.2 \pm 0.3$ & $\begin{array}{l}3025 \pm \\
185\end{array}$ \\
\hline XC05-140 & 140 & $\begin{array}{l}4.73 \quad \pm \\
1.77 \mathrm{E}-1\end{array}$ & $\begin{array}{l}20.94 \pm \\
8.01 \mathrm{E}-1\end{array}$ & $\begin{array}{l}0.741 \pm \\
0.04\end{array}$ & $0.07 \pm 0.01$ & $2.21 \pm 0.09$ & $7.1 \pm 0.1$ & $\begin{array}{l}3219 \pm \\
133\end{array}$ \\
\hline XC05-239 & 239 & $\begin{array}{l}4.36 \pm \\
1.69 \mathrm{E}-1\end{array}$ & $\begin{array}{l}21.86 \pm \\
8.35 \mathrm{E}-1\end{array}$ & $\begin{array}{l}0.74 \pm \\
0.045\end{array}$ & $0.07 \pm 0.01$ & $2.17 \pm 0.08$ & $7.3 \pm 0.1$ & $\begin{array}{l}3360 \pm \\
138\end{array}$ \\
\hline XC05-340 & 340 & $\begin{array}{l}4.34 \quad \pm \\
1.66 \mathrm{E}-1\end{array}$ & $\begin{array}{l}20.72 \pm \\
7.98 \mathrm{E}-1\end{array}$ & $\begin{array}{l}0.71 \pm \\
0.04\end{array}$ & $0.06 \pm 0.01$ & $1.99 \pm 0.07$ & $7.4 \pm 0.1$ & $\begin{array}{l}3718 \pm \\
147\end{array}$ \\
\hline $\mathrm{XC05-440}$ & 440 & $\begin{array}{l}4.16 \pm \\
1.62 \mathrm{E}-1\end{array}$ & $\begin{array}{l}2.21 \\
8.3 \mathrm{E}-1\end{array} \pm$ & $\begin{array}{l}0.791 \pm \\
0.04\end{array}$ & $0.06 \pm 0.01$ & $2.06 \pm 0.08$ & $8.4 \pm 0.1$ & $\begin{array}{l}4086 \pm \\
159\end{array}$ \\
\hline
\end{tabular}

Table 5 - Radiocarbon ages of sediment cores EMB13-07, EMB13-13, EMB13-17 and EMB13-21.

\begin{tabular}{lllll}
\hline Sample & $\begin{array}{l}\text { Analyzed } \\
\text { material }\end{array}$ & $\begin{array}{l}\text { Depth } \\
(\mathbf{c m})\end{array}$ & $\begin{array}{l}\mathbf{1}^{\mathbf{1 4}} \text { C Age } \\
\text { (years BP) }\end{array}$ & $\begin{array}{l}\text { Calibrated }{ }^{\mathbf{1 4}} \text { C age } \\
\text { (cal years BP) }\end{array}$ \\
\hline EMB13-07 A & leaf & 210 & $3185 \pm 15$ & $4158-4234$ \\
EMB13-07 B & leaf & 303 & $3180 \pm 15$ & $4156-4232$ \\
EMB13-07 C & leaf & 373 & $3805 \pm 20$ & $4154-4228$ \\
EMB13-07 D & leaf & 458 & $3975 \pm 15$ & $4420-4437$ \\
EMB13-07 E & leaf & 532 & $4765 \pm 25$ & $5479-5580$ \\
EMB13-13 B & charcoal & 210 & $765 \pm 15$ & $681-688$ \\
EMB13-13 C & leaf & 248 & $835 \pm 15$ & $730-741$ \\
EMB13-17 C & leaf & 230 & $145 \pm 15$ & $141-267$ \\
EMB13-17 D & charcoal & 240 & $360 \pm 20$ & $334-467$ \\
EMB13-21 B & charcoal & 260 & $425 \pm 15$ & $499-505$ \\
\hline
\end{tabular}

Luminescence and radiocarbon ages allowed the calculation of sedimentation rates for the organic-rich sediments of the Xingu Ria. In the Xingu Ria, sedimentation rates calculated through luminescence ages of core XC05 varied between $0.27 \mathrm{~cm} \mathrm{yr}^{-1}$ and $0.70 \mathrm{~cm}$ $\mathrm{yr}^{-1}$ (average of $0.37 \mathrm{~cm} \mathrm{yr}^{-1}$ ). The rate of deposition of core XC05 increases from about 0.28 $\mathrm{cm} \mathrm{yr}^{-1}$ during the period of $\sim 4,100$ to $\sim 3,300$ years ago to an average of $0.60 \mathrm{~cm} \mathrm{yr}^{-1}$ during the period of $\sim 3,300$ to $\sim 3,000$ years ago. Cores $\mathrm{XC02}$ and $\mathrm{XC03}$ presented average sedimentation rates of $0.36 \mathrm{~cm} \mathrm{yr}^{-1}$ and $0.31 \mathrm{~cm} \mathrm{yr}^{-1}$, respectively. Sedimentation rates for organic-rich sediments underneath floodplain sediments of the Xingu Ria head were $0.24 \mathrm{~cm}$

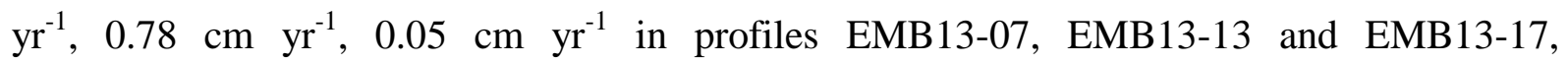
respectively (Figure 4). In the Tapajós Ria, sedimentation rates were calculated through 
radiocarbon ages presented in Irion (2006). Rates of sediment deposition in the Tapajós Ria vary from $0.24 \mathrm{~cm} \mathrm{yr}^{-1}$ to $0.65 \mathrm{~cm} \mathrm{yr}^{-1}$ (average of $0.37 \mathrm{~cm} \mathrm{yr}^{-1}$ ).

Magnetic susceptibility measurements were performed on the XC05 core. Low-field magnetic susceptibility varies from $3.4 \times 10^{-8}$ to $1.9 \times 10^{-7} \mathrm{~m}^{3} \mathrm{~kg}^{-1}$ (Figure 5). Strong magnetic susceptibility variations (peaks) may indicate variations in sedimentation rate or increased magnetic mineral concentrations. The dendogram of geochemical data demonstrates abrupt shifts in the compositional similarity of sediments deposited at 3,690-3,650, 3,345-3,335 and 3,235-3,240 years ago. These shifts fit well with peaks in magnetic susceptibility and $\mathrm{P}, \mathrm{Fe}$, $\mathrm{Mn}$, and TIC concentration as well as with the decrease in TOC and lithophilic elements (Figure 5).

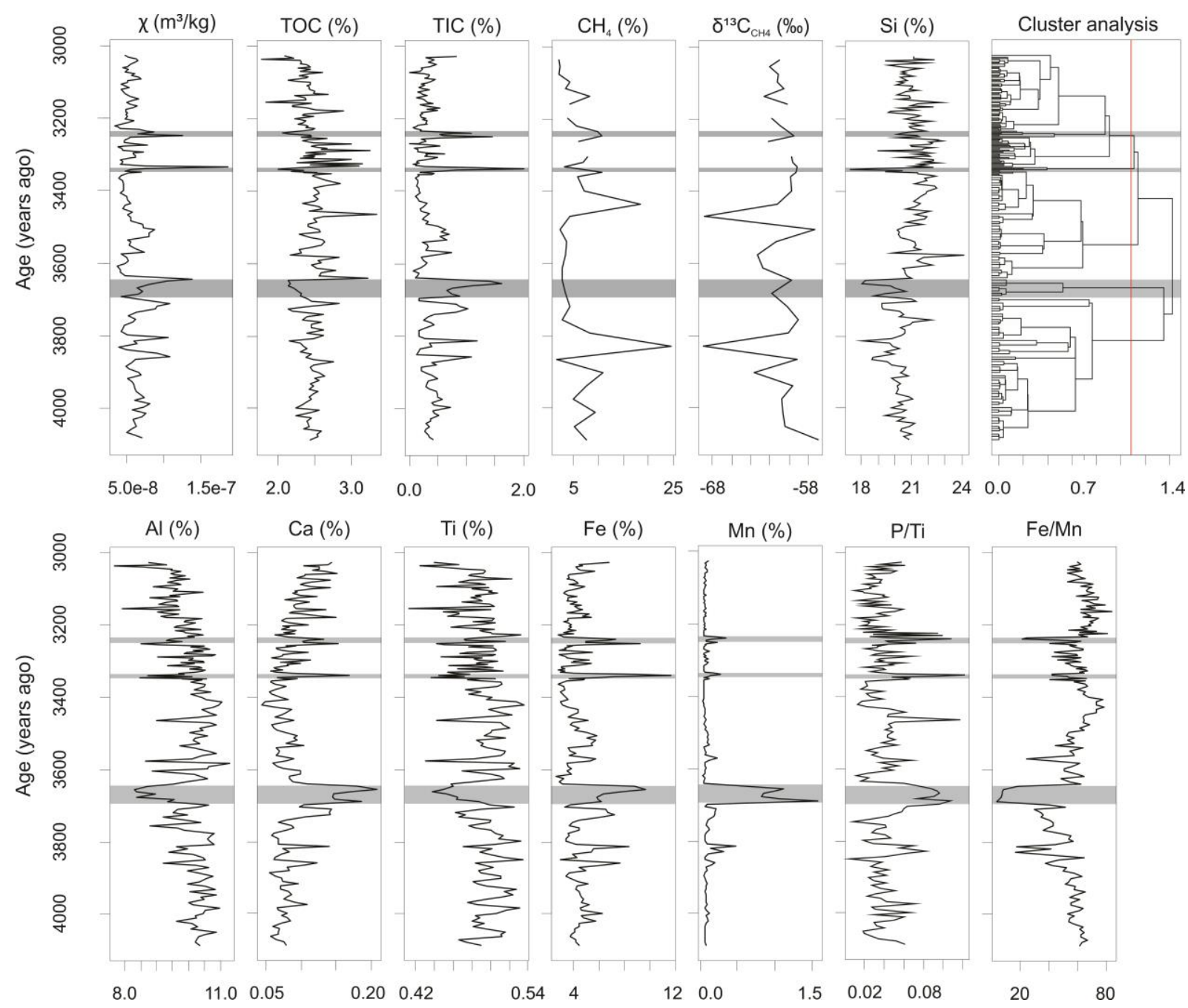

Figure 5 - Variation of magnetic susceptibility $(\chi), \mathrm{CH}_{4}$ concentration, $\delta^{13} \mathrm{C}_{\mathrm{CH} 4}$ and major elements geochemistry in sediment core XC05. Grey areas reveal abrupt shifts in compositional similarity of sediments highlighted by hierarchical cluster analysis. 
Ti concentration reveals significant positive correlations with $\mathrm{Al}(\mathrm{r}=0.81, \mathrm{n}=198)$ and $\mathrm{K}(\mathrm{r}=0.75, \mathrm{n}=198)$. These elements were used as proxies for the relative contribution of terrigenous sediment input from the Xingu River to the downstream Xingu Ria lake (Boës et al., 2011; Engstrom and Wright, 1984). Results show significant inverse correlation among P concentration and lithophilic elements represented by $\mathrm{Ti}(\mathrm{r}=-0.31, \mathrm{n}=198), \mathrm{Al}(\mathrm{r}=-0.32$, $\mathrm{n}=198)$ and $\mathrm{K}(\mathrm{r}=-0.46, \mathrm{n}=198)$. P concentration also shows significant positive correlations with Fe (r=0.57, 198), TIC (r=0.51, $\mathrm{n}=198)$ and $\mathrm{Mn}(\mathrm{r}=0.51, \mathrm{n}=198)$.

TOC concentration varies between $1.77 \%$ and $3.35 \%$ (average of $2.45 \%$ ) in sediment core XC05. The measured concentrations are similar to values in samples from bottom sediments of the Xingu Ria (Häggi et al., 2016). Values of $\delta^{13} \mathrm{C}_{\text {org }}$ range from -31.04 to 27.49\%, and indicate that organic matter from bottom sediments of the Xingu Ria is mainly derived from arboreal C3 vegetation (Supplementary Material, Table S1). This is supported by palynological data, with pollen assemblages dominated by forest taxa (Supplementary Material, Figure S1).

$\mathrm{CH}_{4}$ concentrations in pore waters reach values up to $25 \%$ (volume) in $\mathrm{XC05}$ sediment core (Figure 5). The values of $\delta^{13} \mathrm{C}_{\mathrm{CH} 4}$ in pore waters of XC05 core range from -71 to $-57 \%$ PDB. Higher (more positive) values of $\delta^{13} \mathrm{C}_{\mathrm{CH} 4}$ often agree with peaks in magnetic susceptibility, Fe concentration and P/Ti (Figure 5). This suggests that $\mathrm{CH}_{4}$ oxidation in pore waters might increase during drier periods.

\subsection{Discussion}

Despite the relatively low suspended load in clearwater rivers, the composition of suspended sediments in the Xingu and Tapajós rivers are organic-rich in comparison with white water rivers, showing a marked variation between the dry and wet seasons. Major variations in sediment composition occur due to seasonal changes of hydrology, driving the input of organic and inorganic compounds and regulating primary productivity. The seasonal changes in river discharge controls the relative concentrations of lithophilic elements (Ti, $\mathrm{Al}$, $\mathrm{K})$ compared to elements influenced by redox conditions in the water column and riverbed (P, $\mathrm{Fe}, \mathrm{Mn}$ ). While the uncertainty of organic carbon sources and its stability through time limits its use as proxy for lake productivity or paleo-redox conditions, phosphorous concentration is a useful indicator of paleo-productivity (Boyle, 2001; Dean and Gorham, 1998; Engstrom and Wright, 1984). In order to compensate for fluctuations in allochthonous (terrigenous) inputs of sediments to the ria lake, the $\mathrm{P}$ to Ti ratio was chosen as productivity indicator (Filippelli et 
al., 2003; Latimer and Filippelli, 2002). Average P/Ti values vary from 4.20 to 0.66 in suspended sediments of the Xingu River during the dry and wet seasons, respectively. The higher values during the dry season are linked to higher primary productivity favored by low water turbidity.

There are significant positive correlations between $\mathrm{Fe}$ and $\mathrm{Ca}(\mathrm{p}=0.71, \mathrm{n}=198), \mathrm{Fe}$ and $\mathrm{P}(\mathrm{p}=0.57, \mathrm{n}=198)$ and Fe and TIC $(\mathrm{p}=0.97, \mathrm{n}=198)$ concentrations in core XC05, which point to biogeochemical controls on Fe and TIC deposition in sediments. The high concentration of $\mathrm{Fe}$ relative to $\mathrm{K}$ in suspended sediments transported during the dry season suggests that assimilation of $\mathrm{Fe}$ in sediments is favored by the increase in organic productivity and oxygenated bottom waters (Table 3). Major decreases in TOC concentrations are correlated to peaks of $\mathrm{P} / \mathrm{Ti}$, TIC, Fe and Mn, suggesting lower preservation of organic matter during drier periods (Figure 5). The lack of correlation between TOC and TIC in core XC05 indicates that the shallow bathymetry during drier low-water periods likely decreased calcite solubility, enhanced evaporation and led to the elevated concentration of the carbonate ions (Kelts and Talbot, 1990). Mn and Fe in sediments are remobilized under reducing conditions and precipitated in the presence of oxygenated waters (Davison, 1993). Lower values of $\mathrm{Fe} / \mathrm{Mn}$ ratios, proposed by Mackereth (1966) as a redox proxy, are correlated with peaks of $\mathrm{P} / \mathrm{Ti}$, suggesting abrupt shifts in redox conditions during sediment deposition in the Xingu Ria. Peaks of P/Ti indicate dominant wetter conditions punctuated by dry events at 3,6903,650, 3,345-3,335 and 3,235-3,240 years ago (Figure 5). Nutrient-rich and oxygenated waters favor the accumulation of $\mathrm{P}, \mathrm{Fe}$ and $\mathrm{Mn}$ in sediments deposited under drier and lowwater level periods. In contrast, TOC is negatively correlated with $\mathrm{P}, \mathrm{Fe}$ and $\mathrm{Mn}$ concentrations due to the lower organic matter preservation under oxic conditions prevailing during drier periods. During the low water season, the shallower water column would be better mixed and the oxic water in contact with the bottom sediment would lead to a faster degradation of the deposited organic matter. Thus, considering the redox and productivity proxies already described, the variation in TOC concentration through time is mainly derived from changes in the water-sediment interface from anoxic/dysoxic (higher TOC) to oxic (lower TOC) conditions that may be related to hydrologic changes in the area drained by the Xingu River.

Fine-grained sediments accumulated in Amazon rias have relatively high concentration of organic carbon (average TOC of 2.45\%) compared to fine-grained sediments deposited in floodplains under influence of white water rivers such as the Amazon River (0.4\% to 1.4\%; Aniceto et al., 2014; Moreira et al., 2014; Moreira-Turcq et al., 2004). Thus, 
rias formed in large clearwater rivers such as the Xingu and Tapajós rivers act as hotspots for carbon storage within rivers in the Amazon Basin. These areas are present at least since the middle Holocene, considering the ages obtained for the sediment cores from the Xingu (> 4,000 years, this study) and Tapajós rivers (>9,600 years, Irion et al., 2006). Stable carbon isotope data $\left(\delta^{13} \mathrm{C}_{\text {org }}\right.$ from -31.04 to $-27.49 \%$ ) indicate a dominant contribution of $\mathrm{C} 3$ plants and possibly phytoplankton for the organic particles accumulated in the ria bottom. Palynological data document a large contribution of C3 arboreal plants as major sources of carbon in sediments of the Xingu and Tapajós rias. The labile organic matter derived from phytoplankton may be rapidly consumed and turned into $\mathrm{CO}_{2}$ in the oxic surface sediment layer, while the more recalcitrant terrestrial organic matter accumulates. Also, once buried in the anoxic sediment, the autochthonous and labile organic matter may be used to fuel the $\mathrm{CH}_{4}$ production within sediments. This mechanism is in accord with the high $\mathrm{CH}_{4}$ concentrations in pore waters and released to the atmosphere obtained by this work and by Sawakuchi et al. (2014). Despite the large carbon storage, the Xingu and Tapajós rias show the highest fluxes of $\mathrm{CH}_{4}$ to the atmosphere among the major Amazon tributaries (Sawakuchi et al., 2014), suggesting that sedimentary conditions suitable for organic matter preservation favor anoxic conditions in the sediments, where $\mathrm{CH}_{4}$ can be produced and released to the atmosphere. This is supported by the high concentrations (up to $24 \%$ ) of $\mathrm{CH}_{4}$ in sediment pore waters of the Xingu Ria, with $\delta^{13} \mathrm{C}_{\mathrm{CH} 4}$ varying from -70.4 to $-56.9 \%$, suggesting low $\mathrm{CH}_{4}$ oxidation rates. These results indicate that rias in clearwater Amazon rivers are significant organic carbon sinks and sources of $\mathrm{CH}_{4}$ to the atmosphere. They should be considered as distinct environments in the Amazon in order to refine modern carbon balance assessments.

The pollen assemblages show a high diversity of arboreal taxa, pointing to the terra firme and igapó forests as main sources of organic matter within sediments of the Xingu River catchment. Despite the increasing deforestation in the Xingu catchment during the last several decades (Barona et al., 2010), organic carbon stored in riverbed sediments is mainly derived from forest. This could be related to a delay in transfer of the deforestation signal to river sediments, or a dominant input of organic matter from the igapó flooding forest tract along the river channel. The diatom assemblages in riverbed sediments and the sediment core point to a slack water environment in the Xingu Ria since the middle Holocene. Considering that the organic matter pool in sediments of the Xingu and Tapajós rias is mainly terrigenous and derived from forested areas, the input of carbon to the ria sediments is favored during high precipitation episodes while carbon preservation is controlled by duration and frequency of dry periods. Low sedimentation rates combined with well oxygenated waters due to higher 44 
primary productivity in the water column favor organic matter degradation in riverbed sediments during dry periods. Despite high rates of organic matter degradation during lowwater periods, the higher primary productivity favors the uptake of $\mathrm{CO}_{2}$ and carbon recycling in the water column and riverbed. During high-water phases, the flux of $\mathrm{CO}_{2}$ to the atmosphere increases due to lower primary productivity, while higher sedimentation rates favor organic matter preservation and carbon uptake in sediments. High primary production is the main indicator of $\mathrm{CO}_{2}$ undersaturation observed in large clearwater rivers in the Amazon during the low-water phase (Rasera et al., 2013).

The sediment cores retrieved in the Xingu Ria have ages varying from 3,025 \pm 185 to $4,086 \pm 159$ years (XC05), from $118 \pm 81$ to $1,251 \pm 211$ years (XC03) and from 2,503 \pm 462 to $3,295 \pm 542$ years $(\mathrm{XC} 02)$. The cores were collected in the deepest part of the river profile and

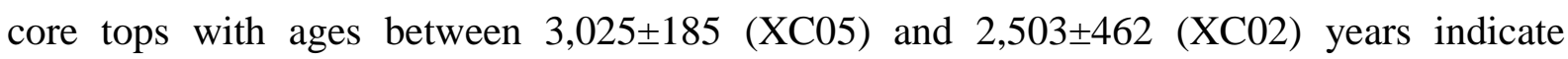
erosional processes and sediment reworking within the ria. The lack of recent deposits indicates that erosion due to channel migration may remobilize sediments in certain portions of the ria. The average sedimentation rate obtained in this study for the Xingu Ria is $0.35 \mathrm{~cm}$ $\mathrm{yr}^{-1}$ since the middle Holocene ( 4,000 years). On millennial timescales, sediment deposition rates at different locations are relatively stable. A similar average sedimentation rate of 0.37 $\mathrm{cm} \mathrm{yr}^{-1}$ was also observed for the Tapajós Ria over the last $\sim 11,000$ years (Irion, 2006). Sedimentation rates from 0.35 to $0.37 \mathrm{~cm} \mathrm{yr}^{-1}$ are relatively high compared to sedimentation rates observed in low latitude lakes, which are typically around 0.05 to $0.25 \mathrm{~cm} \mathrm{yr}^{-1}$ (Caballero et al., 2006; Chu et al., 2002; Conroy et al., 2008; Cross et al., 2000; Hodell et al., 2005, McGlue et al., 2011). Our data show that sedimentation rates varied through time in core $\mathrm{XC05}$. The temporal and spatial variations in sedimentation rates would result from hydrologic changes and sediment reworking within the Ria. The migration of underwater channels and wave action would be the major autogenic processes responsible for sediment remobilization and spatial changes in sedimentation rates. Temporal variations would also be related to precipitation changes affecting sediment supply and accommodation space within the ria. Additional data are required to calculate sedimentation rates with higher temporal resolution and allow a comparison with paleoprecipitation records. This is necessary to constrain the major controls on sedimentation rates and the role of precipitation changes for carbon burial. The TOC concentration in core XC05 varies from $1.77 \%$ to $3.35 \%$ (average of $2.45 \%$ ), similar to TOC values measured in bottom sediments collected in the Xingu Ria (average of 2.36\%) (Häggi et al., 2016). Irion (2006) showed TOC values with low variation in the Tapajós Ria, varying from $2.2 \%$ to $2.9 \%$ in sediments younger than 7,500 years. The 
high sedimentation rates would reduce the effectiveness of degradation processes, implying that the Xingu and Tapajós rias are potentially massive carbon sinks on a millennial timescale.

We estimated rates of organic carbon burial in the Xingu and Tapajós rias based on a dry bulk density of $1.3 \mathrm{~g} \mathrm{~cm}^{-3}$ for the bottom ria sediments, average sedimentation rates of $0.35 \mathrm{~cm} \mathrm{yr}^{-1}$ and $0.37 \mathrm{~cm} \mathrm{yr}^{-1}$ (Irion, 2006) for the Xingu and Tapajós rias, respectively, and the minimum and maximum TOC concentrations obtained in this work and by Irion (2006). In the Xingu Ria, carbon burial ranges from $84 \mathrm{~g} \mathrm{~m}^{-2} \mathrm{yr}^{-1}$ to $159 \mathrm{~g} \mathrm{~m}^{-2} \mathrm{yr}^{-1}$ (average of $116 \mathrm{~g} \mathrm{~m}^{-2}$ $\mathrm{yr}^{-1}$ ) and from 106 to $169 \mathrm{~g} \mathrm{~m}^{-2} \mathrm{yr}^{-1}$ (average of $121 \mathrm{~g} \mathrm{~m}^{-2} \mathrm{y}^{-1}$ ) in the Tapajós Ria. Assuming that $75 \%$ (conservative estimate) of the ria surface is covered by fine-grained organic-rich

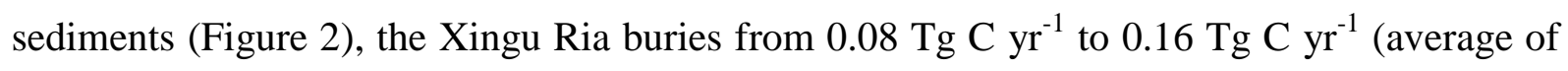

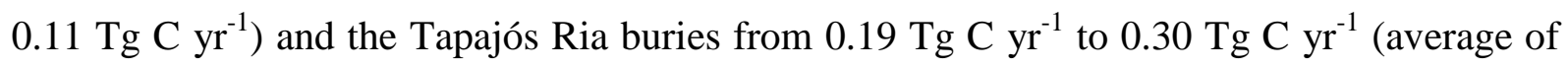

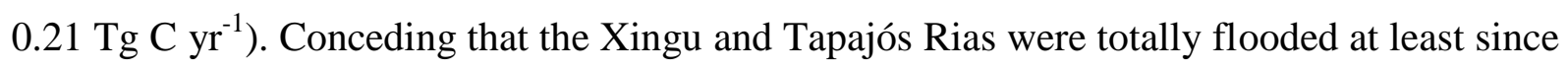
the middle Holocene ( 5,000 years), around $560 \mathrm{Tg} \mathrm{C}$ and $1050 \mathrm{Tg} \mathrm{C}$ of carbon are stored in sediments of the Xingu and Tapajós rias, respectively.

A rough attempt to estimate the carbon budget of the Xingu Ria is possible considering the average accumulation rate of carbon in sediments of the Xingu Ria of $0.11 \mathrm{Tg}$

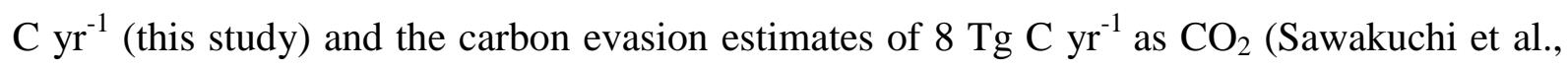
this volume) and $0.053 \mathrm{Tg} \mathrm{C} \mathrm{yr}^{-1}$ as $\mathrm{CH}_{4}$ (Sawakuchi et al., 2014) fluxes to the atmosphere. These estimates indicate that despite the significant carbon pool and storage, the Xingu Ria is a net source of carbon to the atmosphere. Furthermore, the Xingu Ria can serve as an analogue for sediment accumulation and carbon processing in the reservoirs of the Belo Monte hydropower plant. The multidecadal carbon sedimentation pattern estimated for the Xingu Ria allows projections about sediment accumulation and carbon processing in the Belo Monte reservoirs.

\subsection{Conclusions}

The lowermost sectors of the Tapajós and Xingu rivers have lake-like (fluvial ria) sedimentary dynamics due to the impoundment by the Amazon mainstream during the Holocene. This lake-like physiography hinders the transfer of sediments to the Amazon River and induces the accumulation of fine-grained organic-rich sediments derived from upstream areas. Thus, the downstream reaches of these major clearwater rivers are sinks for particulate organic matter chiefly derived from arboreal forest (terra firme and igapó). Wetter periods favor the supply and preservation of forest-derived organic matter in sediments while drier 
periods increase the organic productivity in the water column and favor degradation of organic matter in riverbed sediments. Microbial consumption of organic matter in the oxic surface layers of the sediment contributes to the anoxic conditions that prevail within sediments, with methanogenesis being an important path for biodegradation of particulate organic matter. During dry and low-water level periods, the flux of $\mathrm{CH}_{4}$ to the atmosphere increases while the $\mathrm{CO}_{2}$ flux decreases due to the higher organic productivity within the water column. Thus, seasonal variations play an important role for carbon dynamics in clearwater rivers. Despite the significant carbon storage that occurs in the Xingu and Tapajós rias at least since the middle Holocene, our carbon balance estimates indicate that Amazon rias would act as source of carbon to the atmosphere. A future drier climate as projected for Eastern Amazonia would reduce the carbon sink potential of clearwater rivers and increase the methane flux to the atmosphere.

\subsection{Conflicts of Interest}

The authors declare the absence of any commercial or financial relationships that could be construed as a potential conflict of interest.

\subsection{Funding}

This study was funded by FAPESP grants \#2011/06609-1, \#2014/23334-4, \#2016/02656-1 and CAPES grant \#AUXPE 2043/2014.

\subsection{Author Contributions}

DJB, AOS and HOS were responsible for design of the study and preparation of the manuscript. AOS, HOS, GAH, DJB and FNP organized overall project logistics. DJB and HOS executed the sampling and analysis of $\mathrm{CH}_{4}$ in sediment core and performed calculations of carbon balance. FNP and AOS executed luminescence dating. GAH performed magnetic susceptibility analysis. MM, FNP and DJB performed sampling and geochemical analysis of the sediment core. CMC, MZ and ES executed geochemical analysis of suspended and riverbed sediments. TSP collaborated with sediment and greenhouse gas sampling and supported local logistics. RAS and PEO executed palynology analysis. SBF and DCB performed diatom analysis. All authors contributed to data interpretation and critically revised the manuscript for final submission. 


\subsection{Acknowledgments}

We thank Luciana Nogueira and Thays Desiree Mineli for the support with luminescence dating procedures. Bailee Hodelka, Joseph Lucas, and Jason Backus assisted with XRF and coulometry measurements. We also thank the reviewers for constructive criticisms and valuable comments. Open access publication fees were supported by the Gordon and Betty Moore Foundation Marine Microbial Initiative.

\subsection{References}

Abril, G., Martinez, J.M., Artigas, L. F., Moreira-Turcq, P., Benedetti, M. F., Vidal, L., et al. 2014. Amazon River carbon dioxide outgassing fuelled by wetlands. Nature 505, 395-8. doi:10.1038/nature12797.

Algeo, T. J., and Rowe, H. 2012. Paleoceanographic applications of trace-metal concentration data. Chem. Geol. 324-325, 6-18. doi:10.1016/j.chemgeo.2011.09.002.

Almeida, C. A. de, Coutinho, A. C., Esquerdo, J. C. D. M., Adami, M., Venturieri, A., Diniz, C. G., et al. 2016. High spatial resolution land use and land cover mapping of the Brazilian Legal Amazon in 2008 using Landsat-5/TM and MODIS data. Acta Amaz. 46, 291-302. doi:10.1590/1809-4392201505504.

Aniceto, K., Moreira-Turcq, P., Cordeiro, R. C., Fraizy, P., Quintana, I., and Turcq, B. 2014. Holocene paleohydrology of Quistococha Lake (Peru) in the upper Amazon Basin: Influence on carbon accumulation. Palaeogeogr. Palaeoclimatol. Palaeoecol. 415, 165174. doi:10.1016/j.palaeo.2014.08.018.

Archer, A. W. 2005. Review of Amazonian Depositional Systems. Fluv. Sedimentol. VII, 1739. doi:10.1002/9781444304350.ch2.

Armstrong-Altrin, J. S., and Machain-Castillo, M. L. 2016. Mineralogy, geochemistry, and radiocarbon ages of deep sea sediments from the Gulf of Mexico, Mexico. J. South Am. Earth Sci. 71, 182-200. doi:10.1016/j.jsames.2016.07.010.

Aufdenkampe, A. K., Mayorga, E., Raymond, P. A., Melack, J. M., Doney, S. C., Alin, S. R., et al. 2011. Riverine coupling of biogeochemical cycles between land, oceans, and 
atmosphere. Front. Ecol. Environ. 9, 53-60. doi:10.1890/100014.

Barona, E., Ramankutty, N., Hyman, G., and Coomes, O. T. 2010. The role of pasture and soybean in deforestation of the Brazilian Amazon. Environ. Res. Lett. 5, 24002. doi:10.1088/1748-9326/5/2/024002.

Barros, N., Cole, J. J., Tranvik, L. J., Prairie, Y. T., Bastviken, D., Huszar, V. L. M., et al. 2011. Carbon emission from hydroelectric reservoirs linked to reservoir age and latitude. Nat. Geosci. 4, 593-596. doi:10.1038/ngeo1211.

Battarbee, R. W., Jones, V. J., Flower, R. J., Cameron, N. G., Bennion, H., Carvalho, L., et al. 2001. "Diatoms," in Tracking Environmental Change Using Lake Sediments: Terrestrial, Algal, and Siliceous Indicators, eds. J. P. Smol, H. J. B. Birks, W. M. Last, R. S. Bradley, and K. Alverson (Dordrecht: Springer Netherlands), 155-202. doi:10.1007/0306-47668-1_8.

Bertani, T. C., Rossetti, D. F., Hayakawa, E. H., and Cohen, M. C. L. 2014. Understanding Amazonian fluvial rias based on a Late Pleistocene-Holocene analog. Earth Surf. Process. Landforms. doi:10.1002/esp.3629.

Bicudo, D.C., Tremarin, P.I., Almeida, P.D., Almeida-Zorzal, S., Wengrat, S., Faustino, S.B., et al. 2016. Taxonomy and ecology of Aulacoseira species (Bacillariophyta) from tropical reservoirs in Brazil. Diatom Research. 31(2): 199-215.

Boës, X., Rydberg, J., Martinez-Cortizas, A., Bindler, R., and Renberg, I. 2011. Evaluation of conservative lithogenic elements $(\mathrm{Ti}, \mathrm{Zr}, \mathrm{Al}$, and $\mathrm{Rb}$ ) to study anthropogenic element enrichments in lake sediments. J. Paleolimnol. 46, 75-87. doi:10.1007/s10933-011-9515$\mathrm{Z}$.

Bond, G., Showers, W., Cheseby, M., Lotti, R., Almasi, P., DeMenocal, P., et al. 1997. A Pervasive Millennial-Scale Cycle in North Atlantic Holocene and Glacial Climates. Science (80-. . 278, 1257-1266. doi:10.1126/science.278.5341.1257.

Böning, P., Cuypers, S., Grunwald, M., Schnetger, B., and Brumsack, H. J. 2005. Geochemical characteristics of Chilean upwelling sediments at $\sim 36^{\circ}$ S. Mar. Geol. 220, 1-21. doi:10.1016/j.margeo.2005.07.005. 
Bouchez, J., Beyssac, O., Galy, V., Gaillardet, J., France-Lanord, C., Maurice, L., et al. 2010. Oxidation of petrogenic organic carbon in the Amazon floodplain as a source of atmospheric CO2. Geology 38, 255-258. doi:10.1130/G30608.1.

Bouchez, J., Gaillardet, J., Lupker, M., Louvat, P., France-Lanord, C., Maurice, L., et al. 2012. Floodplains of large rivers: Weathering reactors or simple silos? Chem. Geol. 332333, 166-184. doi:10.1016/j.chemgeo.2012.09.032.

Boyle, J. F. 2001. "Inorganic Geochemical Methods in Palaeolimnology," in Tracking Environmental Change Using Lake Sediments: Physical and Geochemical Methods, eds. W. M. Last and J. P. Smol (Dordrecht: Springer Netherlands), 83-141. doi:10.1007/0306-47670-3_5.

van Breukelen, M. R., Vonhof, H. B., Hellstrom, J. C., Wester, W. C. G., and Kroon, D. 2008. Fossil dripwater in stalagmites reveals Holocene temperature and rainfall variation in Amazonia. Earth Planet. Sci. Lett. 275, 54-60. doi:10.1016/j.eps1.2008.07.060.

Caballero, M., Vázquez, G., Lozano-García, S., Rodríguez, A., Sosa-Nájera, S., RuizFernández, A. C., et al. 2006. Present limnological conditions and recent (ca. 340 yr) palaeolimnology of a tropical lake in the Sierra de Los Tuxtlas, eastern Mexico. J. Paleolimnol. 35, 83-97. doi:10.1007/s10933-005-7427-5.

California Academy of Sciences (2011. Catalogue of Diatom Names. Compil. by Elisabeth Fourtanier J. Patrick Kociolek. Available at: http://research.calacademy.org/research/diatoms/names/index.asp [Accessed October 1, 2016].

Cheng, H., Sinha, A., Cruz, F. W., Wang, X., Edwards, R. L., D’Horta, F. M., et al. 2013. Climate change patterns in Amazonia and biodiversity. Nat. Commun. 4, 1411. doi:10.1038/ncomms2415.

Chu, G., Liu, J., Sun, Q., Lu, H., Gu, Z., Wang, W., et al. 2002. The "Mediaeval Warm Period" drought recorded in Lake Huguangyan, tropical South China. The Holocene 12, 511-516. doi:10.1191/0959683602hl566ft.

Cole, J. J., Prairie, Y. T., Caraco, N. F., McDowell, W. H., Tranvik, L. J., Striegl, R. G., et al. 
2007. Plumbing the Global Carbon Cycle: Integrating Inland Waters into the Terrestrial Carbon Budget. Ecosystems 10, 172-185. doi:10.1007/s10021-006-9013-8.

Colinvaux, P. A., De Oliveira, P. E., and Patiño, J. E. M. 1999. Amazon: Pollen Manual and Atlas. Dordrecht: Harwood Academic Publishers.

Conroy, J. L., Overpeck, J. T., Cole, J. E., Shanahan, T. M., and Steinitz-Kannan, M. 2008. Holocene changes in eastern tropical Pacific climate inferred from a Galápagos lake sediment record. Quat. Sci. Rev. 27, 1166-1180. doi:10.1016/j.quascirev.2008.02.015.

Cross, S. L., Baker, P. A., Seltzer, G. O., Fritz, S. C., and Dunbar, R. B. 2000. A new estimate of the Holocene lowstand level of Lake Titicaca, central Andes, and implications for tropical palaeohydrology. The Holocene 10, 21-32. doi:10.1191/095968300671452546.

Costa-Böddeker, S., Bennion, H., Jesus, T.A., Albuquerque, A.L.S., Figueira, R.C.L. \& Bicudo, D.C. 2012. Paleolimnologically inferred eutrophication of a shallow tropical urban reservoir, Southeast Brazil. Journal of Paleolimnology 48(4): 751-766.

Cruz, F. W., Vuille, M., Burns, S. J., Wang, X., Cheng, H., Werner, M., et al. 2009. Orbitally driven east-west antiphasing of South American precipitation. Nat. Geosci. 2, 210-214. doi:10.1038/ngeo444.

Davison, W. 1993. Iron and Manganese in lakes. Earth-Science Rev. 34, 119-163.

Dean, W. E. 1999. The carbon cycle and biogeochemical dynamics in lake sediments. J. Paleolimnol. 21, 375-393. doi:10.1023/A:1008066118210.

Dean, W. E., and Gorham, E. 1998. Magnitude and significance of carbon burial in lakes, reservoirs, and peatlands. Geology 26, 535-538. doi:10.1130/00917613(1998)026<0535:MASOCB>2.3.CO.

Dearing, J. A., Dann, R. J. L., Hay, K., Lees, J. A., Loveland, P. J., and Maher, B. A. 1996. Frequency-dependent susceptibility measurements of environmental materials. Geophys J. Int., 12, 228-240.

Denys, L., Muylaert, K., Krammer, K., Joosten, T., Reid, M., and Rioual, P. 2003. Aulacoseira subborealis stat. nov. (Bacillariophyceae): A common but neglected 
plankton diatom. Nov. Hedwigia 77, 407-427. doi:10.1127/0029-5035/2003/0077-0407.

Engleman, E. E., Jackson, L. L., and Norton, D. R. 1985. Determination of carbonate carbon in geological materials by coulometric titration. Chem. Geol. 53, 125-128. doi:10.1016/0009-2541(85)90025-7.

Engstrom, D. R., and Wright Jr, H. E. 1984. Chemical stratigraphy of lake sediments as a record of environmental change. Lake sediments Environ. Hist. Stud. palaeolimnology Palaeoecol. honour Winifred Tutin.

EPE/MME, E. de P. E.-M. de M. e E. 2007. Plano Nacional de Energia 2030--PNE 2030. Rio Janeiro EPE/MME.

Erdtman, G. 1952. Pollen Morphology and Plant Taxonomy. Geol. Föreningen i Stock. Förhandlingar 74, 526-527. doi:10.1080/11035895209453507.

de Faria, F. A. M., Jaramillo, P., Sawakuchi, H. O., Richey, J. E., and Barros, N. 2015. Estimating greenhouse gas emissions from future Amazonian hydroelectric reservoirs. Environ. Res. Lett. 10, 124019. doi:10.1088/1748-9326/10/12/124019.

Fearnside, P. M. 2014. Impacts of Brazil's Madeira River Dams: Unlearned lessons for hydroelectric development in Amazonia. Environ. Sci. Policy 38, 164-172. doi:10.1016/j.envsci.2013.11.004.

Field, C. B. 1998. Primary Production of the Biosphere: Integrating Terrestrial and Oceanic Components. Science 281, 237-240. doi:10.1126/science.281.5374.237.

Filippelli, G. M., Sierro, F. J., Flores, J. A., Vázquez, A., Utrilla, R., Pérez-Folgado, M., et al. 2003. A sediment-nutrient-oxygen feedback responsible for productivity variations in Late Miocene sapropel sequences of the western Mediterranean. Palaeogeography, Palaeoclimatology, Palaeoecology, 335-348. doi:10.1016/S0031-0182(02)00613-2.

Galbraith, R. F., Roberts, R. G., Laslett, G. M., Yoshida, H., Olley, J. M., Galbraith, R. F., et al. 1999. Optical dating of single and multiple grains of quartz from Jinmium rock shelter, Northern Australia: Part I, Experimetal design and statistical models. Archaeometry 41, 339-364. doi:10.1111/j.1475-4754.1999.tb00987.x. 
Grimm, E. C. 2011. TILIA software version 1.7.16. Illinois State Museum, Research and Collection Center. Springfield USA.

Guérin, G., Mercier, N., Adamiec, G. 2011. Dose-rate conversion factors: update. Ancient TL 29(1), 5-8.

Haberzettl, T., Corbella, H., Fey, M., Janssen, S., Lucke, A., Mayr, C., et al. 2007. Lateglacial and Holocene wet--dry cycles in southern Patagonia: chronology, sedimentology and geochemistry of a lacustrine record from Laguna Potrok Aike, Argentina. The Holocene 17, 297-310. doi:10.1177/0959683607076437.

Häggi, C., Sawakuchi, A.O., Chiessi, C.M., Mulitza, S., Mollenhauer, G., Sawakuchi, H.O., et al., 2016. Origin, transport and deposition of leaf-wax biomarkers in the Amazon Basin and the adjacent Atlantic. Geochimica et Cosmochimica Acta 192, 149-165. doi:10.1016/j.gca.2016.07.002

Hamilton, P. B., and Siver, P. A. 2010. A Morphological Investigation of Eunotia fennica (Bacillariophyceae) from a Freshwater Acidic Pond in Newfoundland, Canada. Proc. Acad. Nat. Sci. Philadelphia 160, 89-98. doi:10.1635/053.160.0110.

Haworth, E. Y. 1988. Distribution of diatom taxa of the old genus Melosira (now mainly Aulacoseira) in Cumbrian waters. Algae Aquat. Environ., 138-167.

Herron, M. M. 1988. Geochemical classification of terrigenous sands and shales from core or $\log$ data. J. Sediment. Res. 58, 820-829. doi:10.1306/212F8E77-2B24-11D7$8648000102 \mathrm{C} 1865 \mathrm{D}$.

Hodell, D. A., Brenner, M., and Curtis, J. H. 2005. Terminal Classic drought in the northern Maya lowlands inferred from multiple sediment cores in Lake Chichancanab (Mexico). Quat. Sci. Rev. 24, 1413-1427. doi:10.1016/j.quascirev.2004.10.013.

Irion, G., Bush, M. B., Nunes de Mello, J. A., Stüben, D., Neumann, T., Müller, G., et al. 2006. A multiproxy palaeoecological record of Holocene lake sediments from the Rio Tapajós, Eastern Amazonia. Palaeogeogr. Palaeoclimatol. Palaeoecol. 240, 523-535. doi:10.1016/j.palaeo.2006.03.005.

Irion, G., de Mello, J. A. S. N., Morais, J., Piedade, M. T. F., Junk, W. J., and Garming, L. 
2011. "Development of the Amazon Valley During the Middle to Late Quaternary: Sedimentological and Climatological Observations," in Amazonian Floodplain Forests: Ecophysiology, Biodiversity and Sustainable Management, eds. J. W. Junk, F. M. T. Piedade, F. Wittmann, J. Schöngart, and P. Parolin (Dordrecht: Springer Netherlands), 27-42. doi:10.1007/978-90-481-8725-6_2.

Jackson, L. L., and Roof, S. R. 1992. Determination of the Forms of Carbon in Geologic Materials. Geostand. Newsl. 16, 317-323. doi:10.1111/j.1751-908X.1992.tb00495.x.

Jarvie, D. M., 1991. Total organic carbon (TOC) analysis, in Merrill, R.K., ed., Treatise of Petroleum Geology: Handbook of Petroleum Geology, Source and Migration Processes and Evaluation Techniques: Tulsa, American Association of Petroleum Geologists, 113118.

Keim, G., Irion, G., Behling, H., Junk, W. J., and Nunes de Mello, J. 1999. The sediment deposits of Lago Calado, a Ria Lake in Central Amazonia (Brazil), as indicator for postglacial water level rise of the Amazon River. - Extended abstract (8 pages) in the Abstract-Volume (CD-Rom) of the international Symposium on "Hydrological. 5-9.

Krammer, K. 2000. The genus Pinnularia. In: Diatoms of the European inland waters and comparable habitats. Volume 1. (Lange-Bertalot, H. Eds), pp. 1-703.

Latimer, J. C., and Filippelli, G. M. 2002. Eocene to Miocene terrigenous inputs and export production: Geochemical evidence from ODP Leg 177, Site 1090. Palaeogeogr. Palaeoclimatol. Palaeoecol. 182, 151-164. doi:10.1016/S0031-0182(01)00493-X.

Latrubesse, E. M., Stevaux, J. C., and Sinha, R. 2005. Tropical rivers. Geomorphology 70, 187-206. doi:10.1016/j.geomorph.2005.02.005.

Mackereteh, F. J. H. 1966. Some Chemical Observations on Post-Glacial Lake Sediments. Philos. Trans. R. Soc. B Biol. Sci. 250, 165-213.

Marengo, J. A. 2004. Interdecadal variability and trends of rainfall across the Amazon basin. Theor. Appl. Climatol. 78, 79-96. doi:10.1007/s00704-004-0045-8.

McGlue, M.M., Silva, A., Corradini, F.A., Zani, H., Trees, M.A., Ellis, G.S., Parolin, M., Swarzenski, P.W., Cohen, A.S. and Assine, M.L. 2011. Limnogeology in Brazil's 
"forgotten wilderness": a synthesis from the large floodplain lakes of the Pantanal. J Paleolimnol, 46(2), 273-289. doi: 10.1007/s10933-011-9538-5

Meade, R.H., Rayol, J.M., Conceição, S.C., Natividade, J.R.G. 1991. Backwater Effects in the Amazon River Basin of Brazil. Env. Geo. and Water. Sciences. 18(2), 105-114.

Medlin, L. K., and Kaczmarska, I. 2004. Evolution of the diatoms: V. Morphological and cytological support for the major clades and a taxonomic revision. Phycologia 43, 245270. doi:10.2216/i0031-8884-43-3-245.1.

Metzeltin, D. \& Lange-Bertalot, H. 2007. Tropical Diatoms of South America II. Special remarks on biogeographic disjunction. In: Iconographia Diatomologica. Annotated diatom micrographs (H. Lange-Bertalot, ed.. Koeltz Scientific Books, Stuttgart, v.18, p.1-877.

Moreira, L. S., Moreira-Turcq, P., Kim, J. H., Turcq, B., Cordeiro, R. C., Caquineau, S., et al. 2014. A mineralogical and organic geochemical overview of the effects of Holocene changes in Amazon River flow on three floodplain lakes. Palaeogeogr. Palaeoclimatol. Palaeoecol. 415, 152-164. doi:10.1016/j.palaeo.2014.03.017.

Moreira-Turcq, P., Jouanneau, J. M., Turcq, B., Seyler, P., Weber, O., and Guyot, J. L. 2004. Carbon sedimentation at Lago Grande de Curuai, a floodplain lake in the low Amazon region: Insights into sedimentation rates. Palaeogeogr. Palaeoclimatol. Palaeoecol. 214, 27-40. doi:10.1016/j.palaeo.2004.06.013.

Moro, R. S., and Fürstenberger, C. B. 1997. Catálogo dos principais parâmetros ecológicos de diatomáceas não-marinhas., ed. E. da U. E. de P. Grossa Ponta Grossa.

Murray, A. S., and Wintle, A. G. 2000. Luminescence dating of quartz using an improved single-aliquot regenerative-dose protocol. Radiat. Meas. 32, 57-73. doi:http://dx.doi.org/10.1016/S1350-4487(99)00253-X.

Prado, L. F., Wainer, I., Chiessi, C. M., Ledru, M. P., and Turcq, B. 2013. A mid-Holocene climate reconstruction for eastern South America. Clim. Past 9, 2117-2133. doi:10.5194/cp-9-2117-2013.

Prescott, J. R., and Hutton, J. T. 1994. Cosmic ray contributions to dose rates for 
luminescence and ESR dating: Large depths and long-term time variations. Radiat. Meas. 23, 497-500. doi:10.1016/1350-4487(94)90086-8.

R Core Team, 2015. R: A Language and Environment for Statistical Computing. Available at: http://www.r-project.org/.

Reimer, P. J., Bard, E., Bayliss, A., Beck, J. W., Blackwell, P. G., Bronk Ramsey, C., et al. 2013. IntCal13 and Marine13 Radiocarbon Age Calibration Curves 0-50,000 Years cal BP. Radiocarbon 55, 1869-1887. doi:10.2458/azu_js_rc.55.16947.

Richey, J. E., Melack, J. M., Aufdenkampe, A. K., Ballester, V. M., and Hess, L. L. 2002. Outgassing from Amazonian rivers and wetlands as a large tropical source of atmospheric CO2. 6416, 6413-6416.

Ring, E., 1989. The preperation and certification of fourteen South African silicate rocks for use as a reference materials. MIntek Report M393.

Roubik, D. W., and Moreno, E. 1991. Pollen and spores of Barro Colorado Island [Panama]. Monogr. Syst. Bot. from Missouri Bot. Gard. 36.

Round, F. E., Crawford, R. M., and Mann, D. G. 1990. Diatoms: biology and morphology of the genera. Cambridge University Press.

Rowe, H., Hughes, N. and Robinson, K. 2012. The quantification and application of handheld energy-dispersive $\mathrm{x}$-ray fluorescence $(\mathrm{ED}-\mathrm{XRF})$ in mudrock chemostratigraphy and geochemistry. Chem. Geol, 324, 122-131.

Rumrich, U., Lange-Bertalot, H., and Rumrich, M. 2000. Diatoms of the Andes from Venezuela to Patagonia/Tierra del Fuego. Iconogr. Diatomol. 9, 1-649.

Sageman, B. B., Murphy, A. E., Werne, J. P., Ver Straeten, C. A., Hollander, D. J., \& Lyons, T. W. 2003. A tale of shales: the relative roles of production, decomposition, and dilution in the accumulation of organic-rich strata, Middle-Upper Devonian, Appalachian basin. Chemical Geology, 195(1), 229-273.

Sawakuchi, H. O., Bastviken, D., Sawakuchi, A. O., Krusche, A. V., Ballester, M. V. R., and Richey, J. E. 2014. Methane emissions from Amazonian Rivers and their contribution to 
the global methane budget. Glob. Chang. Biol. 20, 2829-2840. doi:10.1111/gcb.12646.

Sawakuchi, A.O., Hartmann, G.A., Sawakuchi, H.O, Pupim, F.N., Bertassoli, D.J., Parra, M., et al., 2015. The Volta Grande do Xingu: reconstruction of past environments and forecasting of future scenarios of a unique Amazonian fluvial landscape. Scientific Drilling, 3, 1-12. doi: 10.5194/sd-3-1-2015

Schulte, S., Mangelsdorf, K., and Rullkötter, J. 2000. Organic matter preservation on the Pakistan continental margin as revealed by biomarker geochemistry. Org. Geochem. 31, 1005-1022. doi:10.1016/S0146-6380(00)00108-X.

Scott, C., \& Lyons, T. W. 2012. Contrasting molybdenum cycling and isotopic properties in euxinic versus non-euxinic sediments and sedimentary rocks: refining the paleoproxies. Chemical Geology, 324, 19-27.

Sioli, H. 1984. "The Amazon and its main affluents: Hydrography, morphology of the river courses, and river types," in The Amazon: Limnology and landscape ecology of a mighty tropical river and its basin, ed. H. Sioli (Dordrecht: Springer Netherlands), 127-165. doi:10.1007/978-94-009-6542-3_5.

Strikis, N. M., Cruz, F. W., Cheng, H., Karmann, I., Edwards, R. L., Vuille, M., et al. 2011. Abrupt variations in South American monsoon rainfall during the Holocene based on a speleothem record from central-eastern Brazil. Geology 39, 1075-1078. doi:10.1130/G32098.1.

Stuiver, M. and Reimer, P. J. 2011. Extended 14C data base and revised CALIB 3.0 14C age calibration program, Radiocarbon, 35, 215-230, 1993.

Kelts, K. \& M. Talbot, 1990. Lacustrine carbonates as geochemical archives of environmental change and biotic/abiotic interactions. In: Tilzer, M. M. \& C. Serruya (eds), Large Lakes: Ecological Structure and Function. Springer-Verlag, Berlin, 288-315.

Talbot, M. R., \& Kelts, K. 1990. Paleolimnological Signatures from Carbon and Oxygen Isotopic Ratios in Carbonates, from Organic Carbon-Rich Lacustrine Sediments: Chapter 6.

Tranvik, L. J., Downing, J. a., Cotner, J. B., Loiselle, S. a., Striegl, R. G., Ballatore, T. J., et 
al. 2009. Lakes and reservoirs as regulators of carbon cycling and climate. Limnol. Oceanogr. 54, 2298-2314.doi:10.4319/1o.2009.54.6_part_2.2298.

Tremarin, P. I., Bertolli, L. M., Faria, D. M. D., Costin, J. C., \& Ludwig, T. A. V. 2009. Gomphonema Ehrenberg e Gomphosphenia Lange-Bertalot (Bacillariophyceae) from Maurício river, Paraná, Brazil. Biota Neotropica, 9(4), 111-130.

van Dam, H., Mertens, A. \& Sinkeldam, J. 1994. A coded checklist and ecological indicator values of freshwater diatoms from the Netherlands. Net. J. Aquat. Ecol. 28:117-133, doi:10.1007/BF02334251.

Vital, H., and Stattegger, K. 2000. Lowermost Amazon River: Evidence of late Quaternary sea-level fluctuations in a complex hydrodynamic system. Quat. Int. 72, 53-60. doi:10.1016/S1040-6182(00)00020-3.

Vuille, M., Burns, S. J., Taylor, B. L., Cruz, F. W., Bird, B. W., Abbott, M. B., et al. 2012. A review of the South American monsoon history as recorded in stable isotopic proxies over the past two millennia. Clim. Past 8, 1309-1321. doi:10.5194/cp-8-1309-2012.

Ward, N. D., Krusche, A. V., Sawakuchi, H. O., Brito, D. C., Cunha, A. C., Moura, J. M. S., et al. 2015. The compositional evolution of dissolved and particulate organic matter along the lower Amazon River-Óbidos to the ocean. Mar. Chem. 177, 244-256. doi:10.1016/j.marchem.2015.06.013.

Winemiller, K. O., McIntyre, P. B., Castello, L., Fluet-Chouinard, E., Giarrizzo, T., Nam, S., et al. 2016. Balancing hydropower and biodiversity in the Amazon, Congo, and Mekong. Science (80-. ). 351, 128-129. doi:10.1126/science.aac7082.

Zalat, A., \& Vildary, S. S. 2007. Environmental change in Northern Egyptian Delta lakes during the late Holocene, based on diatom analysis. Journal of Paleolimnology, 37(2), 273-299.

\subsection{Supplementary Material}

The supplementary material for this article can be found in Appendix II. 


\section{PRE- AND POST-FLOODING EMISSIONS OF METHANE AND CARBON DIOXIDE FROM THE BELO MONTE RESERVOIR AREA (XINGU RIVER, AMAZON BASIN).}

Bertassoli Jr. D.J., Sawakuchi, H.O.S., de Camargo, M.G.P., Araújo, K.R., Alem, V.A.T., Pereira, T.S., Sawakuchi, A.O.,

\subsection{Abstract}

The Belo Monte hydropower complex, in the Xingu River, is the largest hydropower plant in Amazonia and will generate up to $11,2 \mathrm{GW}$ when fully operational. This project is part of a current trend of hydropower expansion towards Amazonia and has raised several concerns about the potential impacts on this important biome. In this study, we evaluate methane and carbon dioxide emissions before and after the flooding of the Belo Monte Reservoir. Annually averaged pre-impoundment gas fluxes obtained in this study were similar to previous estimates and corresponded to $1.7 \pm 0.5 \mathrm{mmol} \mathrm{CH}_{4} \mathrm{~m}^{-2} \mathrm{~d}^{-1}$ and $37.2 \pm 24.2 \mathrm{mmol} \mathrm{CO}_{2} \mathrm{~m}^{-2} \mathrm{~d}^{-1}$ for the main channel and $0.1 \pm 0.1 \mathrm{mmol} \mathrm{CH}_{4} \mathrm{~m}^{-2} \mathrm{~d}^{-1}$ and $318.0 \pm 176.4 \mathrm{mmol} \mathrm{CO}_{2} \mathrm{~m}^{-2} \mathrm{~d}^{-1}$ for soils. The estimated per area gross GHG emissions averaged $12.1 \pm 3.2 \mathrm{mmol} \mathrm{CH}_{4} \mathrm{~m}^{-2} \mathrm{~d}^{-1}$ after the impoundment. The obtained gross emissions from the studied reservoir are significantly higher than global averages and represent an increase of approximately $30 \%$ on gross $\mathrm{CO}_{2}$-equivalent emissions in the reservoir area. This study also suggests that the ratio between flooded area and firm energy capacity appears to be the main predictor for average $\mathrm{CO}_{2}$-equivalent emissions per $\mathrm{kWh}$.

\subsection{Introduction}

The world's rising energy demand and the search for alternatives to fossil-fuel-based power generation rapidly increased the number of hydropower projects in tropical environments. However, studies have raised attention to the negative outcomes of damming the world's largest river basin (Best et al. 2019, Latrubesse et al. 2017). In the Amazon River and its tributaries, hundreds of hydropower dams are expected to affect local populations, nutrient and sediment supplies, fish and birds diversity, flood pulses, and mercury contamination levels (Agostinho et al. 2008, Latrubesse et al. 2017, Forsberg et al. 2017). Additionally, estimations of methane $\left(\mathrm{CH}_{4}\right)$ and carbon dioxide $\left(\mathrm{CO}_{2}\right)$ fluxes from tropical 
reservoirs support the idea that some hydroelectric complexes may not offer significant advantages to thermal power plants in terms of greenhouse gases (GHG) emissions (dos Santos et al., 2006). GHG measurements have only been made in a small proportion of the currently installed reservoirs in the tropics, which limits more robust conclusions (Demarty et al. 2011). Despite that, hydropower plants became a significant destination for certified emission reduction credits issued by the Kyoto Protocol's Clean Development Mechanism (CDM) (FONTE, Fearnside, 2014).

Once possible biases caused by the disproportionate sampling of hotspots (i.e. drawdown areas) and periods of intense ebullition (i.e. caused by fluctuation of the water levels ) are taken into account, assessments of GHG emissions from tropical reservoirs may provide important insights about the impact of installing multiple hydropower systems in these environments. However, inter-comparisons of reservoir GHG emissions should be interpreted with caution, as methods used in these measurements are highly variable across the literature (Deemer et al., 2016).

The Belo Monte complex in the Xingu River is currently the largest hydropower plant in the Amazon Basin (Winemiller et al., 2016). It has one of the largest installed capacities for electricity generation in the world (about $11 \mathrm{GW}$ ) and was built as a run-of-theriver plant (Brasil, 2009). The basic scheme of run-of-the-river hydropower plants consists of the obstruction of the main river course, diverting a significant part of the river flow through a secondary channel (Anderson et al., 2015). Although they may vary in design, the operation of run-of-the-river plants is based on the natural river flow and do not require large reservoirs. Consequently, such projects have been regarded as a more sustainable alternative to storagebased projects (Kumar \& Katoch, 2015). Considering that different types of hydropower projects may have distinct impacts on the GHG budget (Song et al. 2018), the Belo Monte reservoir constitutes an ideal case study for the impacts of run-of-the-river hydropower plants. It may also provide good scientific basis for the projection of GHG emissions of future reservoirs in the Amazon scenario (Best et al. 2019, Latrubesse et al. 2017).

The lack of data regarding pre-impoundment emissions and the magnitude of GHG fluxes right after the reservoir filling is an obstacle to improve net emission models in tropical environments. In this study, assessments of flux and partial pressure data obtained during the first 2 years after the construction of the Belo Monte reservoir are compared to pre-existing $\mathrm{CH}_{4}$ emissions from the impacted area. Measurements covered different environments during high- and low-water seasons and provided important and rare background to understand the magnitude of GHG emissions from this tropical hydroelectric reservoir. 


\subsection{Study Area}

The Xingu River is the second largest tributary in the eastern Amazon (Figure 1). It drains about $500,000 \mathrm{~km}^{2}$ and the regional climate is defined by a rainy season, from December to May, and a dry season, from June to November (Figure 2, ANA, 2017). The Xingu River presents low suspended sediment load and its water discharge varies from about $1,000 \mathrm{~m}^{-3} \mathrm{~s}^{-1}$ to $19,000 \mathrm{~m}^{-3} \mathrm{~s}^{-1}$ (ANA, 2017).
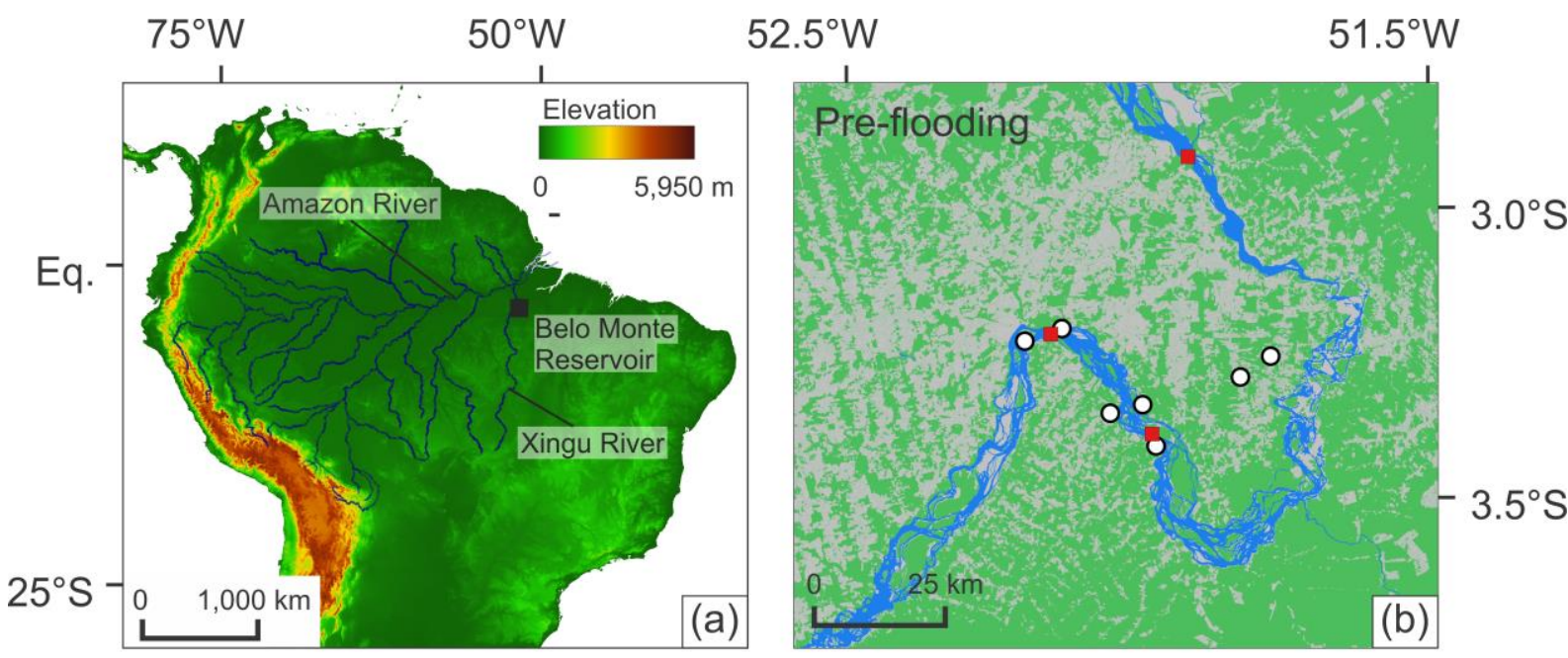

Land cover units

Water surface
$\square$ Forest
$\square$ Pasture and other
non-forested areas
Sampling sites
O Soil
$\square$ Pre-flooding (water surface)
$\square$ Post-flooding (water surface)

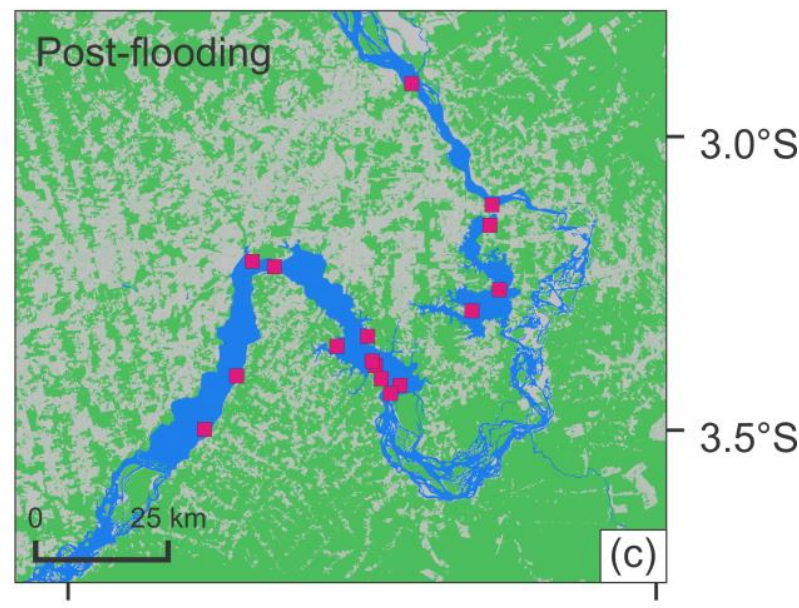

Figure 1- (a) The Amazon Basin and the location of the Belo Monte hydropower complex (Shuttle Radar Topography Mission., Farr et al., 2007); (b,c) Land-use maps (Almeida et al. 2016) and sampling sites of pre(b) and post-impoundment (c) emissions. Individual locations are presented in Table S1 of the Supplementary Material. 


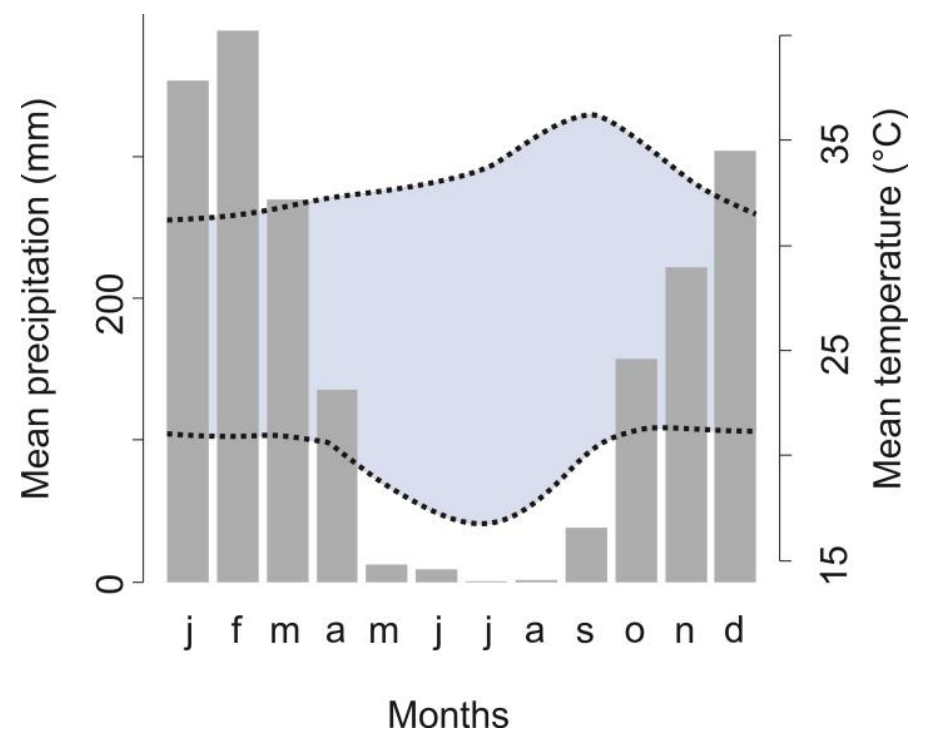

Figure 2 - Mean monthly precipitation and temperatures ranges at the Altamira station (74 $\mathrm{m}$ asl) based on 2003-2013 climatology data (INMET, 2019).

Previous assessments of GHG emissions in Amazonian rivers showed that rivers with relatively low organic and suspended sediment load (clearwater rivers) have the highest potential for $\mathrm{CH}_{4}$ emissions (Sawakuchi et al. 2014). Among them, the Xingu River presented the greatest emissions per area, with total $\mathrm{CH}_{4}$ fluxes being 2 to 100 -fold larger than results from the other Amazonian rivers. The Xingu River also presented the lowest methane oxidation rates (equivalent to 28 to $67 \%$ of the diffusive flux of $\mathrm{CH}_{4}$ ) and the highest ebullition fluxes among other rivers (equivalent to $50 \%$ of the total $\mathrm{CH}_{4}$ emissions) (Sawakuchi et al. 2014; Sawakuchi et al. 2016).

The Belo Monte complex was installed in the lower reach of the Xingu River, over a system of multiple rocky channels known as Volta Grande do Xingu ("Xingu Great Bend", Figure 1). This stretch presents an exceptionally diverse and endemic fish fauna (Camargo et al., 2004; Nogueira et al., 2010) and is full of rapids and waterfalls with high scenic value. Despite the intense controversy regarding the potential socio-environmental impacts of this project, the Belo Monte reservoir was filled during the high-water season of 2016.

The reservoir covers an area of about $515 \mathrm{~km}^{2}$ over a stretch of approximately $80 \mathrm{~km}$ of the Xingu River. According to environmental impact studies presented to the Brazilian government, nearly $122 \mathrm{~km}^{2}$ of this area was previously covered by rainforest, $218 \mathrm{~km}^{2}$ by the river channel, $175 \mathrm{~km}^{2}$ by pasturelands, plantations, secondary and pioneering vegetation, and $1 \mathrm{~km}^{2}$ by urban and mining areas (Brasil, 2009).

In the Belo Monte complex, the Pimental dam redirects most of the water flux from the main channel to the Belo Monte dam through a secondary reservoir. The Belo Monte dam 
holds more than $95 \%$ of the installed capacity (18 turbines), while the Pimental dam mainly regulates the water flow (Brasil, 2009). The intakes of both dams are above the hypolimnion, at a depth of about 15-20 m. The water stage in the reservoir is highly variable and peak energy generation only occurs during periods of maximum water discharge. Since a significant part of the water flux is deviated to generate power, a stretch of about $100 \mathrm{~km}$ downstream of the Pimental dam is subject to reduced supply of water (Brasil, 2009).

\subsection{Materials and Methods}

\subsubsection{Sampling scheme}

Sampling sites were selected considering the heterogeneous hydrologic conditions of the reservoir and the different types of vegetation cover prior to the flooding. We measured $\mathrm{CH}_{4}$ fluxes to the atmosphere 67 times along 23 different sites at the Belo Monte reservoir and surrounding areas (Figure $1 \mathrm{~b}$ and $\mathrm{c}$ ). To establish $\mathrm{CH}_{4}$ emissions from the Xingu River channel before the impoundment, we used data collected by Sawakuchi et al. (2014) during the months of May and November of 2012 and performed an additional sampling survey in November and December of 2014. Sampling surveys to measure emissions from the Belo Monte reservoir after its filling occurred in April of 2016 and in May, September, and October of 2017. Fluxes of $\mathrm{CH}_{4}$ from terrestrial areas close to the reservoir were measured in the months of May, September, and October of 2017. Soil emissions results were used to estimate the background emissions prior to the filling of the Belo Monte reservoir.

Floating chambers were employed to measure $\mathrm{CH}_{4}$ fluxes $\left(\mathrm{FCH}_{4}\right)$ from aquatic environments following the methods described by Bastviken et al. (2010). Simultaneously, water samples were collected from different depths in order to determine the partial pressures of $\mathrm{CH}_{4}\left(\mathrm{pCH}_{4}\right)$ using the headspace extraction method (Bastviken et al. 2010). Depth, water and air temperature, atmospheric pressure and wind speed were controlled using a sonar sensor and a weather station (Kestrel 5500 weather meter; Nielsen-Kellerman Company, Boothwyn, PA, USA) installed in the boat. Physical-chemical variables ( $\mathrm{pH}$ and dissolved oxygen) were measured during three sampling surveys (November of 2012, April of 2016 and May of 2017) using a multiparameter probe (EXO2 multiparameter sonde, YSI Incorporated, Yellow Springs, OH, USA). 


\subsubsection{Flux measurements from surface waters}

$\mathrm{CH}_{4}$ fluxes from surface waters were obtained using 5 chambers with 4 to $12 \mathrm{~L}$, separated approximately $1 \mathrm{~m}$ from each other. Chambers' characteristics and construction followed previously tested setups that showed nonbiased results (Cole et al., 2010; Galfalk et al., 2013). Air samples were retrieved from floating chambers through an outlet using 60-ml syringes and immediately transferred to pre-evacuated glass vials $(20 \mathrm{ml})$ sealed with $10-\mathrm{mm}$ thick butyl rubber stoppers.

Gas concentrations were measured in gas chromatograph (Thermo Scientific TRACE 1310 and Shimadzu GC17A) equipped with an online methanizer coupled to a FID detector and by Cavity Ring Down Spectroscopy using a Picarro G2201-i device. Readings from all analyzers were corrected according to a standard calibration curve.

Total $\mathrm{FCH}_{4}$ and the relative contribution from diffusive and ebullition components were calculated according to Sawakuchi et al. (2014) and Bastviken et al. (2004, 2010). Diffusive flux is described by the equation:

$$
F=k \cdot\left(C_{w}-C_{f c}\right)
$$

Where $\mathrm{F}$ is flux, $\mathrm{k}$ is the gas transfer velocity, $\mathrm{C}_{\mathrm{w}}$ is the measured concentration of $\mathrm{CH}_{4}$ in the water, and $\mathrm{C}_{\mathrm{fc}}$ is the $\mathrm{CH}_{4}$ concentration in the water given equilibrium with $\mathrm{pCH}_{4}$ inside the floating chamber. To obtain the instantaneous flux rate and avoid underestimations linked to the progressive increase of $\mathrm{CH}_{4}$ concentration inside the floating chamber, we calculated diffusive fluxes through Eq. 1 after solving for $\mathrm{k}$ using the following equation:

$$
k=\left(\frac{\delta P}{\delta t}\right) \cdot \frac{V\left(P_{w}-P_{0}\right)}{K_{h} \cdot R \cdot T \cdot A}
$$

Where $\delta \mathrm{P} / \delta \mathrm{t}$ describes the accumulation of $\mathrm{CH}_{4}$ inside the chamber, $\mathrm{V}$ is the chamber volume, $\mathrm{P}_{\mathrm{w}}$ is the $\mathrm{pCH}_{4}$ inside the chamber at equilibrium with the measured concentration of $\mathrm{CH}_{4}$ in the water $\left(\mathrm{C}_{\mathrm{w}}\right), \mathrm{P}_{0}$ is the partial pressure of $\mathrm{CH}_{4}$ in the atmosphere $(\mathrm{t}=0), \mathrm{K}_{\mathrm{h}}$ is the Henry's Law constant for $\mathrm{CH}_{4}, \mathrm{R}$ is the gas constant, $\mathrm{T}$ is temperature, and $\mathrm{A}$ is the surface area of the chamber. 
We used the variation of the apparent temperature-normalized gas transfer velocities $\left(\mathrm{k}_{600}\right)$ to detect chambers that were affected by ebullition (Bastviken et al. 2004). As chambers that received only diffusive fluxes would present similar and lower flux rates, we considered the fluxes of chambers with minimum $\mathrm{k}_{600}$ values as the purely diffusive component. The $\mathrm{k}_{600}$ of individual chambers were divided by the minimum $\mathrm{k}_{600}\left(\mathrm{k}_{600 \min }\right)$ of each sampling site and chambers with ratios above 2 were considered to be significantly affected by ebullition fluxes. The threshold value $(>2)$ was chosen based on the inflection in the frequency distribution of the $\mathrm{k}_{600} / \mathrm{k}_{600 \min }$ ratio (Figure 3 ).

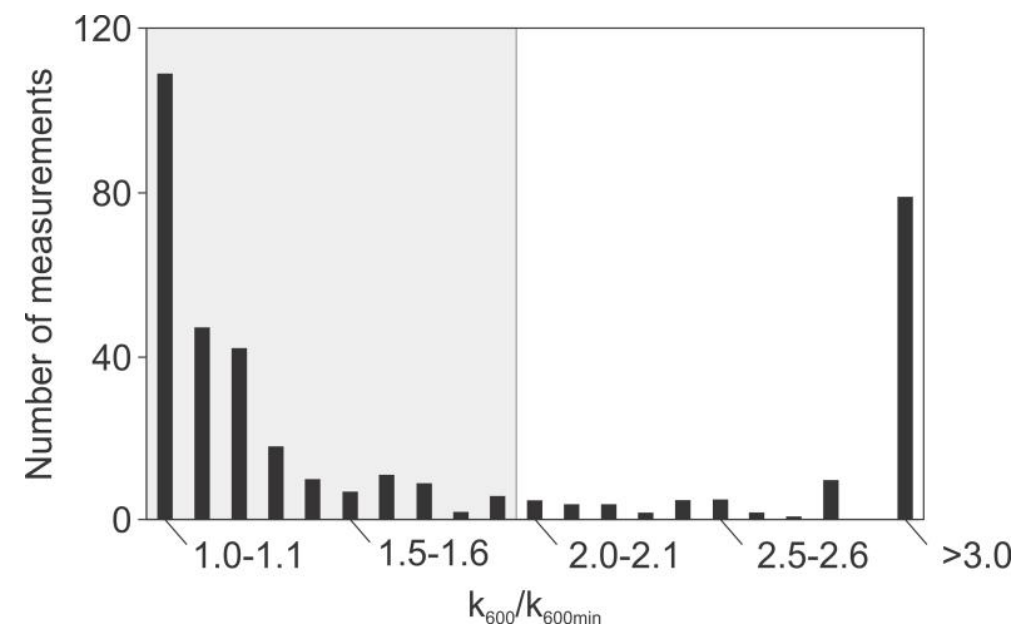

Figure 3- Distribution of $\mathrm{k}_{600} / \mathrm{k}_{600 \min }$ results from all $\mathrm{FCH}_{4}$ measurements.

The diffusive component of chambers with $\mathrm{k}_{600} / \mathrm{k}_{600 \min }$ above 2 was estimated using the averaged $\mathrm{k}_{600}$ from chambers of the same sampling site that only received diffusive flux. The remaining flux into the chambers, estimated by simple linear estimation, was then attributed to ebullition. For estimations of total average fluxes, we summed the average ebullition to the average diffusive flux estimated using the $\mathrm{k}_{600}$.

Pre-impoundment fluxes of $\mathrm{CO}_{2}\left(\mathrm{FCO}_{2}\right)$ from the Xingu River channel were measured during the sampling campaigns of May and November of 2012 using a similar floating chamber as for the $\mathrm{CH} 4$ measurements $(7.7 \mathrm{~L}$, covered with reflexive material) coupled to an infrared gas analyzer (LI-COR® Li820). Changes in $\mathrm{CO}_{2}$ concentration inside the chamber were measured after recirculating the air through the analyzer using a micropump with constant airflow $\left(150 \mathrm{~mL} \mathrm{~min}^{-1}\right)$. The chamber was deployed from a drifting boat for about 5 min during measurements. Three measurements were carried out for each location. In order to reinforce our estimations, we did additional measurements during the dry season of 2014 using $\mathrm{CO}_{2}$ loggers (Bastivekn et al., 2015) inside two plastic chambers used for the $\mathrm{CH}_{4}$ 
flux measurements. These chambers were deployed from a drifting boat for about 30 minutes using a logging frequency of 30 seconds. Measurements for both methods were discarded when the $\mathrm{R}^{2}$ of the linear relation of $\mathrm{pCO}_{2}$ inside the chamber over time was lower than 0.9 . The $\mathrm{F} \mathrm{CO}_{2}$ from the water surface was then calculated using the following equation (Frankignoulle et al., 1998):

$$
F=\left(\frac{\delta P}{\delta t}\right) \cdot \frac{V}{R \cdot T \cdot A}
$$

Where $\delta \mathrm{P} / \delta \mathrm{t}$ describes the accumulation of gases inside the chamber, $\mathrm{V}$ is the chamber volume, $\mathrm{R}$ is the gas constant, $\mathrm{T}$ is temperature, and $\mathrm{A}$ is the surface area of the chamber.

\subsubsection{Estimations of $\mathrm{CH}_{4}$ and $\mathrm{CO}_{2}$ fluxes from soils}

We measured $\mathrm{CH}_{4}$ and $\mathrm{CO}_{2}$ fluxes from the soils of islands and marginal areas of the Xingu River to refine estimates of GHG emissions from the region affected by the Belo Monte reservoir before the impoundment. Sampling sites were distributed along areas with different characteristics and vegetation cover. Measurements occurred during both dry $(n=8)$ and rainy seasons $(n=7)$. Four of the sampling sites were covered by forest and the others by pasture.

Measurements were made using static chambers with $10.6 \mathrm{~L}$ ( $\mathrm{n}=3$ in the dry season and $n=4$ in the rainy season) equipped with a Teflon tube for sampling. The chambers were composed of a PVC ring and a cap that could be separated. The PVC rings were inserted in the soil at depths ranging from 5 to $10 \mathrm{~mm}$ and capped after approximately 3 minutes. After capping, gas samples were retrieved using a 60-ml syringe every 10 minutes for a period of 30 minutes and transferred to evacuated vials. Gas concentration measurements followed the methods previously described in section 3.2. Measurements for both gases were discarded when the $\mathrm{R}^{2}$ of concentration over time was lower than 0.9 (except when variations were lower than $0.1 \mathrm{ppm})$. Fluxes from soils were estimated using Equation 3. 


\subsubsection{Spatio-temporal analysis and upscaling}

The spatiotemporal variability of gross $\mathrm{CH}_{4}$ and $\mathrm{CO}_{2}$ fluxes in the Belo Monte reservoir area was assessed by comparing: (1) differences in average emissions before and after the impoundment; (2) seasonal variations in emissions of different areas; and (3) differences between emissions from the flooded river channel and from marginal areas that were inundated by the Belo Monte reservoir (flooded areas). Wilcoxon-Mann-Whitney tests were used for comparisons due to the non-normal distribution of the obtained data. All statistical analyses were performed in $\mathrm{R}$ ( $\mathrm{R}$ Development Team Core, 2016) using 0.05 as a critical alpha for significance. Uncertainties are reported in this work as standard errors of the mean.

Gross $\mathrm{FCH}_{4}$ fluxes of the Belo Monte Reservoir were estimated by summing the spatially averaged fluxes from the river channel and flooded areas. Obtained values were converted to equivalent $\mathrm{CO}_{2}$ emissions $\left(\mathrm{CO}_{2} \mathrm{eq}\right)$ using the 100 -year global warming potential $\left(\mathrm{GWP}_{\mathrm{fac}}=34\right.$, IPCC, 2013). The total $\mathrm{CO}_{2}$ eq derived from the $\mathrm{CH}_{4}$ emissions were summed to the gross $\mathrm{FCO}_{2}$ emissions obtained by Rabelo et al. (2019), and divided by the firm capacity of the hydropower complex to obtain an estimate of the gross emission factor $\left(\mathrm{EF}_{\text {gross }}\right)$ of the Belo Monte Reservoir, as described by the following equation:

$$
E F_{\text {gross }}=\frac{\left(G W P_{f a c} \cdot \mathrm{FCH}_{4}+\mathrm{FCO}_{2}\right)}{\text { Firm Capacity }}
$$

Pre-flooding gross emissions correspond to the seasonally averaged $\mathrm{FCH}_{4}$ and $\mathrm{FCO}_{2}$ from soils and from the undisturbed river channel. Since we were not able to estimate the effects of vegetation removal, carbon burial rates or $\mathrm{N}_{2} \mathrm{O}$ emissions, we did not try to estimate net GHG emissions in this study. Alternatively, we present the difference between pre- and post-flooding gross $\mathrm{CO}_{2} \mathrm{eq}$ emissions from the reservoir area $\left(\Delta \mathrm{F}_{\text {gross }}\right)$ and its equivalent emission factor. 


\subsection{Results}

\subsubsection{Physico-chemical characteristics of the reservoir}

Wind speeds, $\mathrm{pH}$ and air, and surface water temperatures were relatively similar during pre- and post-flooding sampling stages. Measured surface water temperatures $(29.9 \pm$ $\left.1.2{ }^{\circ} \mathrm{C}\right)$ and air temperatures $\left(30.9 \pm 0.5{ }^{\circ} \mathrm{C}\right)$ were higher during the dry season. Average $\mathrm{pH}$ values $(6.7 \pm 0.1)$ were seasonally and spatially stable.

Wind speeds $\left(2.5 \pm 0.2 \mathrm{~m} \mathrm{~s}^{-1}\right)$ presented significant spatial heterogeneity during the post-flooding sampling stage ( $\mathrm{p}<0.05, \mathrm{n}=31$ ), varying from $1.9 \pm 0.2$ (flooded areas) to $3.2 \pm$ $0.3 \mathrm{~m} \mathrm{~s}^{-1}$ (river channel). Dissolved oxygen was also lower in flooded areas $\left(6.2 \pm 0.5 \mathrm{mg} \mathrm{L}^{-1}\right)$ than in the main channel $\left(6.9 \pm 0.1 \mathrm{mg} \mathrm{L}^{-1}\right)$ during the analyzed period (Dry season of 2017).

\subsubsection{Pre-flooding emissions in the Belo Monte area}

$\mathrm{FCH}_{4}$ from soils of the Belo Monte area ranged from -0.8 to $1.3 \mathrm{mmol} \mathrm{m}^{-2} \mathrm{~d}^{-1}$ (Table 1). $\mathrm{FCO}_{2}$, on the other hand, ranged from 61 to $1415 \mathrm{mmol} \mathrm{m}^{-2} \mathrm{~d}^{-1}$ and accounted for roughly $90 \%$ of measured gross pre-flooding emissions. Wilcoxon-Mann-Whitney tests do not show significant differences between pasture and forest-covered soils $(\mathrm{W}=146, \mathrm{p}>0.05, \mathrm{n}=38)$. However, fluxes are substantially higher during the rainy season (Table $1, \mathrm{~W}=269, \mathrm{p}<0.05$, $\mathrm{n}=40)$.

Pre-impoundment $\mathrm{FCH}_{4}$ in the Xingu River ranged from 0.3 to $5.0 \mathrm{mmol} \mathrm{m}^{-2} \mathrm{~d}^{-1}$ with significantly higher emissions during the dry season (Table 1). Values of $\mathrm{pCH}_{4}$ follow this same patterns, averaging $0.04 \pm 0.01 \mu \mathrm{M}$ during the rainy season $(\mathrm{n}=3)$ and $0.20 \pm 0.02 \mu \mathrm{M}$ during the dry season $(\mathrm{n}=6) . \mathrm{FCO}_{2}$ spanned from -31.9 to $17.8 \mathrm{mmol} \mathrm{m}^{-2} \mathrm{~d}^{-1}$ during the dry season and 19.0 to $177.6 \mathrm{mmol} \mathrm{m} \mathrm{m}^{-2}$ during the rainy season (Table 1). Ebullition fluxes were identified in four of the nine measurements during the pre-impoundment campaign (about 44\%). Average diffusive fluxes varied from 0.2 to $2.5 \mathrm{mmol} \mathrm{m}^{-2} \mathrm{~d}^{-1}$ and accounted for about $70 \%$ of total emissions from a single measurement. $\mathrm{FCO}_{2} \mathrm{eq}$ values are considerably higher in soils than in the river channel. 
Table 1 - Average $\mathrm{FCH}_{4}, \mathrm{FCO}_{2}$ (from Rabelo et al., 2019), $\mathrm{FCO}_{2}$ eq, diffusive $\mathrm{FCH}_{4}\left(\mathrm{FdCH}_{4}\right.$,), and percentage of ebullition (Ebull.). Data of individual samples are presented in Tables S1 and S2 of the Supplementary Material. n.a.=not available. Ds.=Downstream of the reservoir

\begin{tabular}{|c|c|c|c|c|c|c|}
\hline & & $\begin{array}{l}\mathrm{FCH}_{4} \\
\left(\mathrm{mmol} \mathrm{m}^{2} \mathbf{d}^{-1}\right)\end{array}$ & $\begin{array}{l}\mathrm{FCO}_{2} \\
\left(\mathrm{mmol} \mathrm{m}^{2} \mathrm{~d}^{-1}\right)\end{array}$ & $\begin{array}{l}\mathrm{FCO}_{2} \mathbf{e q} \\
\left(\mathrm{mmol} \mathrm{m}^{2} \mathbf{d}^{-1}\right)\end{array}$ & $\begin{array}{l}\mathrm{FdCH}_{4} \\
\left(\mathrm{mmol} \mathrm{m}^{2} \mathrm{~d}^{-1}\right)\end{array}$ & $\begin{array}{l}\text { Ebull. } \\
(\%)\end{array}$ \\
\hline Soils & Rainy, $n=14,15$ & $0.3 \pm 0.1$ & $423.1 \pm 336.3$ & $433.3 \pm 336.3$ & n.a. & n.a. \\
\hline$\sum_{x}$ & Dry, $n=24,30$ & $-0.1 \pm 0.1$ & $212.9 \pm 106.2$ & $209.5 \pm 106.3$ & n.a. & n.a. \\
\hline ¿ Channel & Rainy, $\mathrm{n}=3$ & $1.2 \pm 0.7$ & $84.2 \pm 47.9$ & $125 \pm 53.5$ & $1.2 \pm 0.7$ & $1.74 \pm 1.74$ \\
\hline & Dry, $n=6$ & $2.2 \pm 0.8$ & $-9.7 \pm 7.4$ & $65.1 \pm 28.2$ & $0.9 \pm 0.2$ & $39.6 \pm 15.4$ \\
\hline \multirow{6}{*}{ 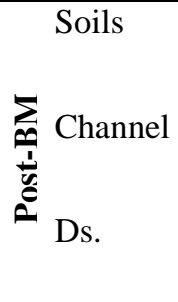 } & Rainy, $n=15$ & $21.6 \pm 8.1$ & $73.1 \pm 9.6$ & $807.5 \pm 275.6$ & $11.7 \pm 8$ & $64.5 \pm 7.8$ \\
\hline & Dry, $n=9$ & $17.4 \pm 6.5$ & $243.4 \pm 113.6$ & $835 \pm 248.5$ & $9.9 \pm 5.8$ & $51.8 \pm 9.9$ \\
\hline & Rainy, $n=6$ & $1.4 \pm 0.5$ & $110.0 \pm 10.9$ & $157.6 \pm 20.2$ & $1.1 \pm 0.5$ & $12.0 \pm 9.0$ \\
\hline & Dry, $n=4$ & $1.7 \pm 1.1$ & $77.3 \pm 14.2$ & $135.1 \pm 40$ & $1.5 \pm 1.2$ & $29.6 \pm 17.8$ \\
\hline & Rainy, $\mathrm{n}=5$ & $1.1 \pm 0.5$ & $181.1 \pm 27.5$ & $218.5 \pm 32.3$ & $1.1 \pm 0.5$ & $6.4 \pm 3.9$ \\
\hline & Dry, $n=3$ & $0.6 \pm 0.1$ & $28.2 \pm 36.6$ & $48.6 \pm 36.8$ & $0.5 \pm 0.1$ & $1.6 \pm 1.6$ \\
\hline
\end{tabular}

\subsection{3 $\quad \mathrm{CH}_{4}$ emissions from the Belo Monte Reservoir}

Average total $\mathrm{CH}_{4}$ fluxes at individual sampling sites of the Belo Monte Reservoir varied from 0.3 to $121.7 \mathrm{mmol} \mathrm{m} \mathrm{m}^{-2} \mathrm{~d}^{-1}$ (Table 1). Diffusive fluxes accounted for approximately $50 \%$ of total emissions (average $6.9 \pm 3.2 \mathrm{mmol} \mathrm{m}^{-2} \mathrm{~d}^{-1}$ ). Ebullition fluxes were identified in $75 \%$ of the sampling sites, without significant seasonal changes $(\mathrm{W}=52$, $\mathrm{p}>0.05, \mathrm{n}=34) \cdot \mathrm{pCH}_{4}$ and $\mathrm{FCH}_{4}$ were also seasonally stable $(\mathrm{W}=149, \mathrm{p}>0.05, \mathrm{n}=34)$, but with higher values measured over flooded areas (Table 1). $\mathrm{FCO}_{2}$ presented in Table 1 represents the average results obtained from Araújo et al. (2019).

$\mathrm{FCH}_{4}$ and $\mathrm{pCH}_{4}$ from areas downstream of the reservoir, close to the Pimental and Belo Monte dams, were markedly lower than measurements taken upstream of the dams during the dry season (Table 1). During the rainy season, on the other hand, downstream $\mathrm{FCH}_{4}$ and $\mathrm{pCH}_{4}$ are relatively similar to channel values upstream of the dam. $\mathrm{FCO}_{2}$ eq values from flooded areas are seasonally stable and markedly higher than pre-flooding emissions. Noteworthy, except for increased $\mathrm{FCO}_{2}$ during the dry season, emissions from the river channel are relatively similar to pre-flooding results.

Estimations of $\mathrm{F}_{\text {gross }}$ and their respective emission factors are presented in Table 2. Our results indicate that spatially averaged $\mathrm{FCH}_{4}$ from the Belo Monte reservoir was about $12.1 \pm 3.2 \mathrm{mmol} \mathrm{CH} 4 \mathrm{~m}^{-2} \mathrm{~d}^{-1}$ during the first two years after the impoundment. Similarly, estimations based on previous literature (Araújo et al., 2019) suggest $\mathrm{FCO}_{2}$ of approximately $120.0 \pm 26.2 \mathrm{mmol} \mathrm{CO}_{2} \mathrm{~m}^{-2} \mathrm{~d}^{-1}$ during the same period. The obtained values correspond to 
about $0.04 \pm 0.01 \mathrm{Tg} \mathrm{C} \mathrm{yr}^{-1}$ as $\mathrm{CH}_{4}$ and $0.27 \pm 0.06 \mathrm{Tg} \mathrm{C} \mathrm{yr}^{-1}$ as $\mathrm{CO}_{2}$, and are equivalent to

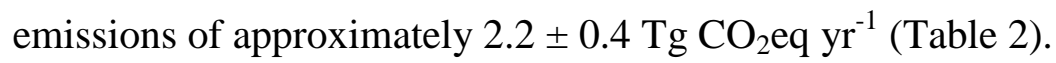

Table 2 - Summary of $\mathrm{CO}_{2}$ eq emissions from the Belo Monte Reservoir. $\Delta$ Estimates represent the $\mathrm{CO}_{2} \mathrm{eq}$ emissions from the Belo Monte Reservoir after subtracting average pre-flooding $\mathrm{CO}_{2}$ eq emissions.

\begin{tabular}{ccc}
\hline Estimate & $\begin{array}{c}\text { Average emissions } \\
\left(\mathbf{T g ~ C O}_{\mathbf{2}} \mathbf{e q ~}_{\mathbf{~}}^{\mathbf{1}}\right)\end{array}$ & $\begin{array}{c}\mathbf{E F} \\
\left.\mathbf{( k g ~ C O}_{\mathbf{2}} \mathbf{e q} / \mathbf{M W h}\right)\end{array}$ \\
\hline Gross & $2.2 \pm 0.4$ & $55.8 \pm 9.8$ \\
$\boldsymbol{\Delta}$ & $0.5 \pm 0.9$ & $12.6 \pm 23.3$ \\
\hline
\end{tabular}

\subsection{Discussion}

Although individually the Belo Monte Reservoir is not representative of global carbon budgets, combined GHG fluxes from reservoir surfaces correspond to about $1.5 \%$ of global anthropogenic emissions over a 100-year time-span (roughly $0.8 \mathrm{Pg} \mathrm{CO}_{2} \mathrm{eq} \mathrm{y}^{-1}$, Deemer et al. 2016). $\mathrm{FCH}_{4}$ values obtained in this study were similar during both dry and rainy seasons and suggested relatively stable emissions in the reservoir area throughout the year. Our data also suggest that flooded areas contributed to the majority of the $\mathrm{FCO}_{2} \mathrm{eq}$ associated with the Belo Monte Reservoir. Seasonally averaged $\mathrm{FCO}_{2} \mathrm{eq}$ in the flooded channel and downstream of the dam are not remarkably different from emissions at the unaltered river channel. This reinforces the significance of spatial variations in estimations of $\mathrm{CH}_{4}$ emissions in newly flooded tropical reservoirs. It also suggests that part of the contrasting results seen in the literature for a single reservoir is probably related to the fact that several estimates are based on a reduced number of sampling sites that could diminish the disproportionate contribution of hotspots (i.e. drawdown areas) and periods of intense ebullition (i.e. caused by fluctuating water levels). Also, as sampling efforts usually occur during a few months of a single year, the majority of estimates only offer a snapshot of the emission rates.

Previous literature suggests that age, latitude, air temperature and chlorophyll $\alpha$ concentrations are suitable predictors for $\mathrm{FCH}_{4}$ and $\mathrm{FCO}_{2}$ (Barros et al. 2011; DelSontro et al., 2010; Deemer et al. 2016). In Figure 4, we compare our results to a dataset of tropical and extratropical reservoirs of different ages (Deemer et al. 2016). Although Deemer et al. (2016) only found a weak correlation between $\mathrm{CH}_{4}$ emissions and latitude ( $\mathrm{p}=0.05, \mathrm{R}^{2}=0.04$ ), the distributions of reported total emissions (diffusive + ebullition) from tropical $(n=20)$ and extratropical $(n=32)$ regions differ significantly (Figure 4, Wilcoxon-Mann-Whitney U=175, $\mathrm{p}<0.05)$. The same occurs for diffusive fluxes $\left(\mathrm{n}_{\text {trop }}=15, \mathrm{n}_{\mathrm{extra}}=91\right.$, Wilcoxon-Mann-Whitney 
$\mathrm{U}=223, \mathrm{p}<0.05)$. If on the one hand, average emissions from the Belo Monte Reservoir are on the higher end of previously published global values, on the other hand, they are quite similar to mean emissions from tropical reservoirs with less than 10 years (Figure 4), independently of reservoir type (storage or run-of-the-river). Hence, the high $\mathrm{CH}_{4}$ and $\mathrm{CO}_{2}$ fluxes obtained in our study possibly result from the combination of rapid decomposition of organic material from flooded soils, high air, and water temperatures.

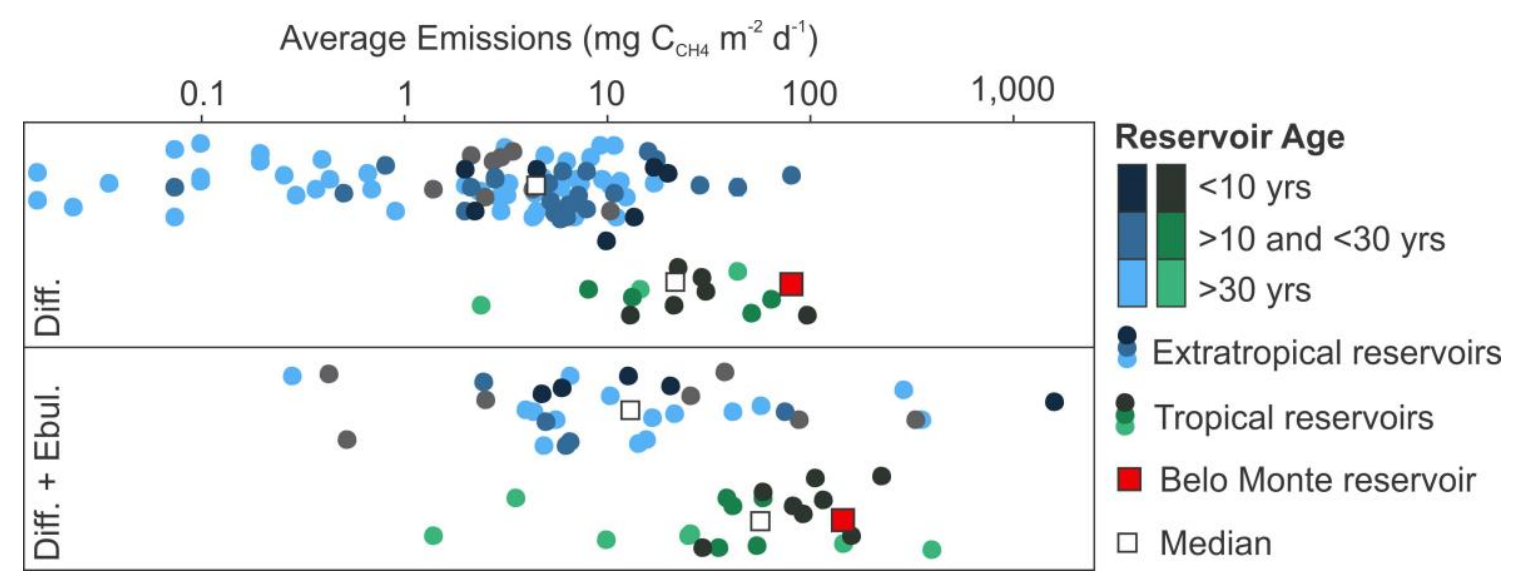

Figure 4 - Compiled data of average $\mathrm{CH}_{4}$ emissions per area (Deemer et al. 2016) compared to Belo Monte data.

Ebullition fluxes may be the major source of uncertainties for gross GHG emissions estimates in the Belo Monte reservoir due to their spatially uneven distribution. Previous assessments conducted on extratropical regions have shown that lower residence times and reservoir volume in run-of-the-river systems may favor particulate organic matter deposition and higher bubbling fluxes than in storage reservoirs (Descloux et al., 2017). Nevertheless, our calculations suggest that ebullition contributed to only $56 \%$ of spatially-averaged total fluxes, which is in agreement with previous estimates for other reservoirs and natural lakes (about 50\%, Deemer et al. 2016; Bastviken et al. 2004). Our results also reinforce the importance of near-shore measurements when evaluating reservoir emissions (Natchimuthu et al. 2015), as seasonally averaged ebullition fluxes from the flooded channel only accounted for about $20 \%$ of total emissions, which could lead to a drastic underestimation of $\mathrm{FCH}_{4}$.

Seasonally averaged $\mathrm{FCH}_{4}$ and $\mathrm{FCO}_{2}$ from the Xingu channel prior to the flooding represented less than $10 \%$ of the total post-flooding $\mathrm{CO}_{2}$ eq emissions. Conversely, soils from the Belo Monte area presented remarkably high $\mathrm{CO}_{2}$ emission rates, releasing about $1.5 \mathrm{Tg}$ $\mathrm{CO}_{2} \mathrm{y}^{-1}$. Considering $\mathrm{FCO}_{2}$ and $\mathrm{FCH}_{4}$ fluxes from soils and aquatic areas prior to the Belo Monte construction, post-flooding gross emissions in the Belo Monte Reservoir represent an increase of about $30 \%$ in average gross $\mathrm{CO}_{2}$ eq fluxes in the affected region (Table 2). 
Estimates of net GHG emissions have demonstrated that carbon burial rates and preimpoundment fluxes are significant and critical to quantify the magnitude of $\mathrm{CH}_{4}$ and $\mathrm{CO}_{2}$ emissions from hydroelectric reservoirs (Abril et al., 2005, dos Santos et al., 2017). However, in the case of the Belo Monte Reservoir, a natural impoundment of the Xingu River by the Amazon mainstem downstream of the Belo Monte dam (Xingu Ria, Bertassoli et al. 2017) already represents an effective trap for Xingu sediments. This feature buries a significant fraction of the organic particulate matter carried by the Xingu waters and halts the degradation of this material further downstream.

Despite the lack of representative data, previous literature reported that run-of-theriver reservoirs have lower emission rates than storage reservoirs (Song et al. 2018). Although per area fluxes in the first years of operation of the Belo Monte reservoir are relatively high, its estimated $\mathrm{EF}_{\text {gross }}$ is one of the lowest among other Brazilian hydroelectric complexes (Figure 5).

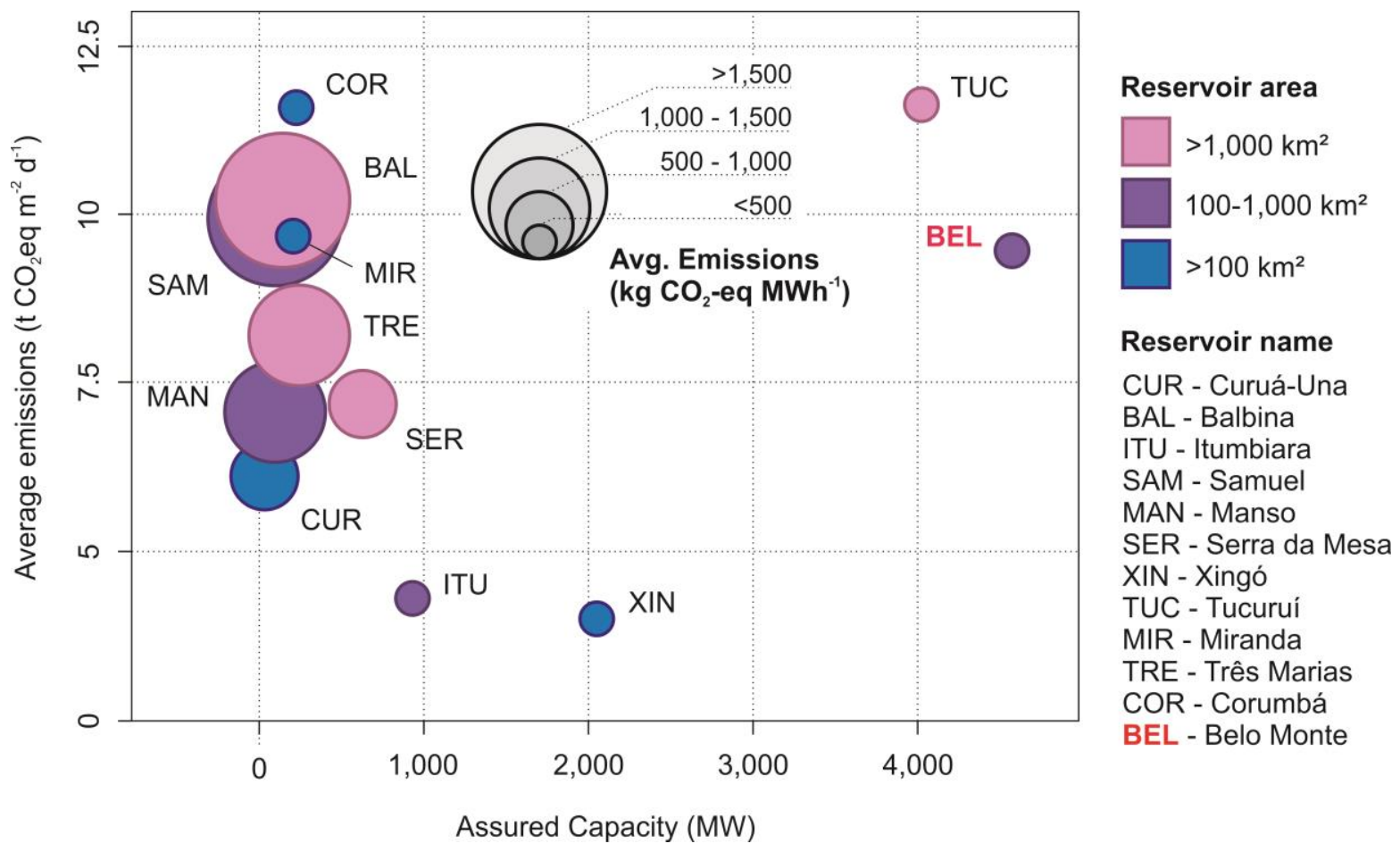

Figure 5 - Mean $\mathrm{CO}_{2} \mathrm{eq}$ emissions per area compared to the Firm capacity of Brazilian hydroelectric powerplants (EPE, 2017). Besides Belo Monte Reservoir (BEL) results, we used emission values compiled by Deemer et al. (2016) from previously published data (Bergier et al. 2011; Duchemin et al. 2000; Guérin et al. 2006; Joyce \& Jewell, 2003; Kemenes et al. 2006; Kemenes et al. 2011; Lima et al. 2002; Lima et al. 2005; Marcelino et al. 2015; Ometto et al. 2013; Roland et al. 2010; Rosa et al. 2003; Rosa et al. 2004; dos Santos et al. 2006; St. Louis et al. 2000).

Such relation is probably related to the strong correlation between $\mathrm{EF}_{\text {gross }}$ and flooded area-firm capacity ratio (Figure 6) and suggests that run-of-the-river reservoirs may be a 
significantly better alternative than storage reservoirs in Amazonia in terms of $\mathrm{EF}_{\text {delta. }}$. In parallel, our results indicate that when it comes to GHG emissions, efforts should be focused on the restrainment of the flooded area, independently of the construction method or reservoir type. We highlight, however, that $\mathrm{N}_{2} \mathrm{O}$ emissions and carbon fluxes associated with vegetation removal, the burial of organic matter or degassing are not included in our estimates and preclude any conclusion regarding the relative climatic impact of different energy sources.

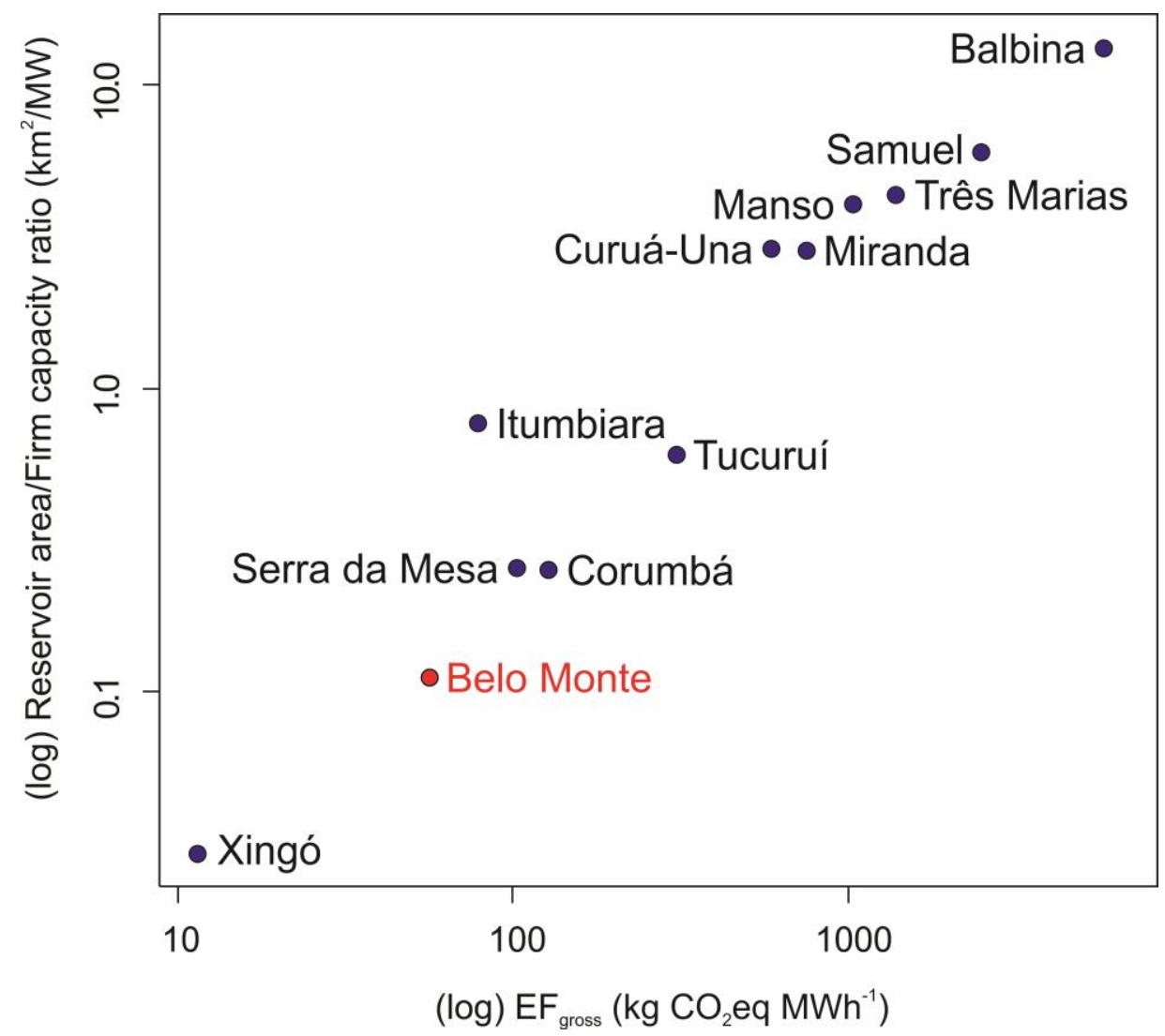

Figure 6 - Scatterplots comparing $\mathrm{EF}_{\text {gross }}$ and the ratio of reservoir area to firm energy capacity $\left(\mathrm{R}^{2}=0.98\right.$, $\mathrm{p}<0.05)$. Axes are in log-scale.

\subsection{Conclusions}

Overall, our results show that $\mathrm{CH}_{4}$ and $\mathrm{CO}_{2}$ emissions during the first two years after the filling of Belo Monte Reservoir were substantially higher (about 30\%) than pre-flooding GHG emissions from the same area. The estimated per area gross GHG emissions $(12.1 \pm 3.2$ mmol CH4 $\mathrm{m}^{-2} \mathrm{~d}^{-1}$ ) were higher than the global median but similar to other tropical reservoirs with different ages (Figure 5). Although it is not our intention to establish the main environmental controls affecting GHG emissions from hydroelectric reservoirs, our results 
reinforce the linkage between the geographic location of hydroelectric reservoirs and their impacts on global GHG budgets. Finally, although different characteristics of the run-of-theriver reservoirs may affect carbon burial rates or methane oxidation for a given environment, the flooded area-firm capacity ratio appears to be the main predictor of $\mathrm{EF}_{\text {gross. }}$.

\subsection{References}

Agostinho A, Gomes L, Veríssimo S, Okada E 2004 Flood regime, dam regulation and fish in the Upper Parana' River: effects on assemblage attributes, reproduction and recruitment. Reviews in Fish Biology and Fisheries 14: 11-19.

Almeida, C. A. de, Coutinho, A. C., Esquerdo, J. C. D. M., Adami, M., Venturieri, A., Diniz, C. G., et al. 2016. High spatial resolution land use and land cover mapping of the Brazilian Legal Amazon in 2008 using Landsat-5/TM and MODIS data. Acta Amaz. 46, 291-302. doi:10.1590/1809-4392201505504.

ANA. 2017. Hidroweb: Sistema de Informações Hidrológicas. Retrieved in August 1, 2017 from http://www.snirh.gov.br/hidroweb/.

Anderson, D., Moggridge, H., Warren, P., \& Shucksmith, J. 2015. The impacts of 'run-ofriver'hydropower on the physical and ecological condition of rivers. Water and Environment Journal, 29(2), 268-276.

Barros, N., Cole, J. J., Tranvik, L. J., Prairie, Y. T., Bastviken, D., Huszar, V. L., ... \& Roland, F. 2011. Carbon emission from hydroelectric reservoirs linked to reservoir age and latitude. Nature Geoscience, 4(9), 593.

Bastviken D, Cole J, Pace M, Tranvik L 2004 Methane emissions from lakes: dependence of lake characteristics, two regional assessments, and a global estimate. Global Biogeochemical Cycles, 18, Gb4009.

Bastviken D, Santoro AL, Marotta H, Pinho LQ, Calheiros DF, Crill P, Enrich-Prast A 2010 Methane emissions from Pantanal, South America, during the low water season: toward more comprehensive sampling. Environmental Science \& Technology, 44, 5450-5455. 
Bastviken, D., Sundgren, I., Natchimuthu, S., Reyier, H., \& Gålfalk, M. 2015. Cost-efficient approaches to measure carbon dioxide $(\mathrm{CO} 2)$ fluxes and concentrations in terrestrial and aquatic environments using mini loggers. Biogeosciences, 12(12), 3849-3859.

Bergier, I., Novo, E. M. L. M., Ramos, F. M., Mazzi, E. A. \& Rasera, M. F. F. L. 2011. Carbon dioxide and methane fluxes in the littoral zone of a tropical savanna reservoir (Corumbá, Brazil). Oecologia Aust. 15, 666-681.

Bertassoli Jr, D. J., Sawakuchi, A. O., Sawakuchi, H. O., Pupim, F. N., Hartmann, G. A., McGlue, M. M., et al. 2017. The fate of carbon in sediments of the Xingu and Tapajós clearwater rivers, eastern Amazon. Frontiers in Marine Science, 4, 44.

Best, J. 2018. Anthropogenic stresses on the world's big rivers. Nature Geoscience, 12 (1): 7 21.

Brasil: Aproveitamento Hidrelétrico Belo Monte, Environmental Impact Study, Eletrobrás, Rio de Janeiro, 426pp, 2009c.

Camargo, M., Giarrizzo, T., \& Isaac, V. 2004. Review of the geographic distribution of fish fauna of the Xingu river basin, Brazil. Ecotropica, 10, 123-147.

Cole, J. J., Prairie, Y. T., Caraco, N. F., McDowell, W. H., Tranvik, L. J., Striegl, R. G., ... \& Melack, J. 2007. Plumbing the global carbon cycle: integrating inland waters into the terrestrial carbon budget. Ecosystems, 10(1), 172-185., P.,

Csiki, S. and Rhoads, B. L.: Hydraulic and geomorphological effects of run-of-river dams, Prog. Phys. Geogr., 34, 755-780,

Deemer, B. R., Harrison, J. A., Li, S., Beaulieu, J. J., DelSontro, T., Barros, N., ... \& Vonk, J. A. 2016. Greenhouse gas emissions from reservoir water surfaces: a new global synthesis. BioScience, 66(11), 949-964.

DelSontro, T., McGinnis, D. F., Sobek, S., Ostrovsky, I., \& Wehrli, B. 2010. Extreme methane emissions from a Swiss hydropower reservoir: contribution from bubbling sediments. Environmental science \& technology, 44(7), 2419-2425.

Demarty, M., \& Bastien, J. 2011. GHG emissions from hydroelectric reservoirs in tropical 
and equatorial regions: Review of 20 years of $\mathrm{CH} 4$ emission measurements. Energy Policy, 39(7), 4197-4206.

Descloux, S., Chanudet, V., Serça, D., \& Guérin, F. 2017. Methane and nitrous oxide annual emissions from an old eutrophic temperate reservoir. Science of the Total Environment, 598, 959-972.doi:10.1177/0309133310369435, 2010.

dos Santos, M. A., Rosa, L. P., Sikar, B., Sikar, E., \& Dos Santos, E. O. 2006. Gross greenhouse gas fluxes from hydro-power reservoir compared to thermo-power plants. Energy Policy, 34(4), 481-488.

dos Santos, M. A., Damazio, J. M., Rogerio, J. P., Amorim, M. A., Medeiros, A. M., Abreu, J. L. S., ... \& Rosa, L. P. (2017). Estimates of GHG emissions by hydroelectric reservoirs: The Brazilian case. Energy, 133, 99-107.

Duchemin, É. et al. 2000. Comparison of greenhouse gas emissions from an old tropical reservoir with those from other reservoirs worldwide. Verhandlungen Int. Ver. Theor. Angew. 27, 1391-1395.

Farr, T. G., Rosen, P. A., Caro, E., Crippen, R., Duren, R., Hens- ley, S., et al. 2007. The shuttle radar topography mission, Rev. Geophys., 45, 10.1029/2005RG000183.

Forsberg, B. R., Melack, J. M., Dunne, T., Barthem, R. B., Goulding, M., Paiva, R. C., ... \& Weisser, S. 2017. The potential impact of new Andean dams on Amazon fluvial ecosystems. PLoS One, 12(8), e0182254.

Frankignoulle, M., Abril, G., Borges, A., Bourge, I., Canon, C., Delille, B., ... \& Théate, J. M. 1998. Carbon dioxide emission from European estuaries. Science, 282(5388), 434-436.

Galfalk M, Bastviken D, Fredriksson S, Arneborg L 2013 Determination of the piston velocity for water-air interfaces using flux chambers, acoustic Doppler velocime- try, and IR imaging of the water surface. Journal of Geophysical Research: Biogeo- sciences, $118,770-782$.

Guérin, F., Abril, G., Richard, S., Burban, B., Reynouard, C., Seyler, P., \& Delmas, R. 2006. Methane and carbon dioxide emissions from tropical reservoirs: significance of downstream rivers. Geophysical Research Letters, 33(21). 
INMET. 2019. Instituto Nacional de Metereologia. Retrieved in May 10, 2019 from http://www.inmet.gov.br/.

Joyce, J., \& Jewell, P. W. 2003. Physical controls on methane ebullition from reservoirs and lakes. Environmental \& Engineering Geoscience, 9(2), 167-178.

Kemenes, A., Forsberg, B. R., \& Melack, J. M. 2007. Methane release below a tropical hydroelectric dam. Geophysical research letters, 34(12).

Kemenes, A., Forsberg, B. R., \& Melack, J. M. 2011. CO2 emissions from a tropical hydroelectric reservoir (Balbina, Brazil). Journal of Geophysical Research: Biogeosciences, 116(G3).

Kumar, D., \& Katoch, S. S. 2015. Sustainability assessment and ranking of run of the river (RoR) hydropower projects using analytical hierarchy process (AHP): A study from Western Himalayan region of India. Journal of Mountain Science, 12(5), 1315-1333.

Latrubesse, E. M., Arima, E. Y., Dunne, T., Park, E., Baker, V. R., d'Horta, F. M., et al., 2017. Damming the rivers of the Amazon basin. Nature, 546(7658), 363.

Lima, I. B. T. 2005. Biogeochemical distinction of methane releases from two Amazon hydroreservoirs. Chemosphere, 59(11), 1697-1702.

Lima, I. B. T., Victoria, R. L., Novo, E. M. L. M., Feigl, B. J., Ballester, M. V. R., \& Ometto, J. P. 2002. Methane, carbon dioxide and nitrous oxide emissions from two Amazonian reservoirs during high water table. Internationale Vereinigung für theoretische und angewandte Limnologie: Verhandlungen, 28(1), 438-442.

Marcelino, A. A., Santos, M. A., Xavier, V. L., Bezerra, C. S., Silva, C. R. O., Amorim, M. A., ... \& Rogerio, J. P. 2015. Diffusive emission of methane and carbon dioxide from two hydropower reservoirs in Brazil. Brazilian Journal of Biology, 75(2), 331-338.

Natchimuthu, S., Sundgren, I., Gålfalk, M., Klemedtsson, L., Crill, P., Danielsson, Å., \& Bastviken, D. (2016). Spatio-temporal variability of lake CH4 fluxes and its influence on annual whole lake emission estimates. Limnology and Oceanography, 61(S1), S13-S26. 
Nogueira, C., Buckup, P. A., Menezes, N. A., Oyakawa, O. T., Kasecker, T. P., Neto, M. B. R., \& da Silva, J. M. C. 2010. Restricted-range fishes and the conservation of Brazilian freshwaters. PloS one, 5(6), e11390.

Ometto, J. P., Cimbleris, A. C., dos Santos, M. A., Rosa, L. P., Abe, D., Tundisi, J. G., ... \& Roland, F. 2013. Carbon emission as a function of energy generation in hydroelectric reservoirs in Brazilian dry tropical biome. Energy policy, 58, 109-116.

Roland, F., Vidal, L. O., Pacheco, F. S., Barros, N. O., Assireu, A., Ometto, J. P., ... \& Cole, J. J. 2010. Variability of carbon dioxide flux from tropical (Cerrado) hydroelectric reservoirs. Aquatic Sciences, 72(3), 283-293.

Rosa, L. P., Dos Santos, M. A., Matvienko, B., dos Santos, E. O., \& Sikar, E. 2004. Greenhouse gas emissions from hydroelectric reservoirs in tropical regions. Climatic Change, 66(1-2), 9-21.

Rosa, L. P., Dos Santos, M. A., Matvienko, B., Sikar, E., Lourenço, R. S. M., \& Menezes, C. F. 2003. Biogenic gas production from major Amazon reservoirs, Brazil. Hydrological Processes, 17(7), 1443-1450.

Sawakuchi, H. O., Bastviken, D., Sawakuchi, A. O., Krusche, A. V., Ballester, M. V. R., and Richey, J. E. 2014. Methane emissions from Amazonian Rivers and their contribution to the global methane budget. Glob. Chang. Biol. 20, 2829-2840. doi:10.1111/gcb.12646.

Song, C., Gardner, K. H., Klein, S. J., Souza, S. P., \& Mo, W. 2018. Cradle-to-grave greenhouse gas emissions from dams in the United States of America. Renewable and Sustainable Energy Reviews, 90, 945-956.

St. Louis, V. L., Kelly, C. A., Duchemin, É., Rudd, J. W., \& Rosenberg, D. M. 2000. Reservoir Surfaces as Sources of Greenhouse Gases to the Atmosphere: A Global Estimate: Reservoirs are sources of greenhouse gases to the atmosphere, and their surface areas have increased to the point where they should be included in global inventories of anthropogenic emissions of greenhouse gases. BioScience, 50(9), 766-775.

Winemiller, K. O., Mcintyre, P. B., Castello, L., Fluet-Chouinard, E., Giarrizzo, T., Nam, S., et al., 2016. Balancing hydropower and biodiversity in the Amazon, Congo, and 
Mekong. Science, 351(6269), 128-129.

\subsection{Supplementary Material}

The supplementary material for this article can be found in Appendix III. 


\section{INTEGRATIVE DISCUSSION}

Individual chapters of this study provide important information regarding several characteristics and processes from natural and human-made environments of Eastern Amazonia. Together, they provide an overview of how different climate conditions and anthropogenic impacts affect river discharges and carbon dynamics in Eastern Amazonia over distinct time frames. Chapter 2 investigate the markedly different geochemical signatures of sediments from the Amazon and Xingu rivers to identify anomalies in their water discharges that possibly affected floodplains ecosystems and human activity at least since 2,5 kyr BP. This chapter also suggests an overall drying trend in the Amazon lowlands and reinforces the spatially different response of Amazonian rainfall to changes in insolation and interhemispheric temperature anomalies. Although the section is focused on past hydrologic dynamics, it may also provide valuable insights regarding future scenarios of spatially heterogeneous precipitation changes. Chapter 3 analyzes sedimentation rates and geochemical signatures of samples collected along the lower Xingu, Tapajós, and Amazon rivers. The manuscript that comprises this chapter aims the characterization of sediment and carbon dynamics in the Xingu Ria and sustains part of the analysis and interpretations presented in Chapter 2. Chapter 4, on the other hand, focuses on the recent anthropogenic impacts occurring in the Xingu River region. It deals with changes in carbon dioxide and methane emissions associated with hydroelectric reservoirs and contributes to a more detailed perspective on how ongoing transformations will affect the Xingu Basin in the near future.

This study shows that regional climate variations modify the hydrologic balance of Amazonian rivers and affect sedimentation and carbon dynamics in fluvial rias. The widespread presence of fluvial rias and the high sediment deposition rates observed in these features suggest that they retain a significant fraction of sediments from rivers draining the Amazon Lowlands. Thus, Amazonian fluvial rias may play an important role in the transport of organic and fine-grained sediments in the Amazon Basin, act as reactors or sinks of carbon and provide remarkable information of variations in the water and sediment discharges of the Amazon River and its tributaries. Climate-related modifications in fluvial rias sum up to other anthropogenic impacts such as land-use change and dam building. Such interventions possibly promote large-scale changes in the hydrology, sediment discharge, and in the carbon balance of Amazonian rivers.

Although the transition of part of Eastern Amazonia to a disturbance-dominated regime seems inevitable, the understanding of how the Amazonian ecosystem will respond to 
the increasing anthropogenic pressure is still very limited. By addressing the initial questions presented in Section 1.2 (Objectives), this thesis shed new light on how part of the system is affected by regional hydroclimate anomalies and by the construction of hydroelectric reservoirs. It also reinforces the sensitivity and the strongly interdependent relation of hydrology, climate, and carbon dynamics in Eastern Amazonia. Looking into the future, this thesis deepens the discussion about extreme hydrological events that could reduce water availability for the maintenance of agricultural productivity, river navigation, and hydroelectric generation. Also, it suggests that the accumulative impacts linked to the construction of multiple hydroelectric reservoirs in the Amazon Basin may be significant to the regional carbon balance. Hence, the incremental behavior of anthropogenic impacts should be considered and influence regional-scale studies and decision-making processes. This will improve assessments and mitigation plans that depend on how this system will react as a whole to the multiple anthropogenic impacts that Amazonia has been facing over the last decades. 


\section{REFERENCES}

Abril, G., Guérin, F., Richard, S., Delmas, R., Galy-Lacaux, C., Gosse, P. et al. 2005. Carbon dioxide and methane emissions and the carbon budget of a 10-year old tropical reservoir (Petit Saut, French Guiana). Global biogeochemical cycles, 19(4).

Best, J. 2019. Anthropogenic stresses on the world's big rivers. Nat Geosci 12 (1): 7-21.

Coe, M. T., Latrubesse, E. M., Ferreira, M. E., \& Amsler, M. L. 2011. The effects of deforestation and climate variability on the streamflow of the Araguaia River, Brazil. Biogeochemistry, 105(1-3), 119-131.

Costa, M. H., Botta, A., \& Cardille, J. A. 2003. Effects of large-scale changes in land cover on the discharge of the Tocantins River, SouthEastern Amazonia. Journal of Hydrology, 283(1-4), 206-217.

Davidson, E. A., de Araújo, A. C., Artaxo, P., Balch, J. K., Brown, I. F., Bustamante, M. M., ... \& Munger, J. W. 2012. The Amazon basin in transition. Nature, 481(7381), 321.

De Faria, F. A., Jaramillo, P., Sawakuchi, H. O., Richey, J. E., \& Barros, N. 2015. Estimating greenhouse gas emissions from future Amazonian hydroelectric reservoirs. Environmental Research Letters, 10(12), 124019.

Delmas, R., Richard, S., Guérin, F., Abril, G., Galy-Lacaux, C., Delon, C., \& Grégoire, A. 2005. Long term greenhouse gas emissions from the hydroelectric reservoir of Petit Saut (French Guiana) and potential impacts. In Greenhouse gas emissions-fluxes and processes (pp. 293-312). Springer, Berlin, Heidelberg.

dos Santos, M. A., Rosa, L. P., Sikar, B., Sikar, E., \& Dos Santos, E. O. 2006. Gross greenhouse gas fluxes from hydro-power reservoir compared to thermo-power plants. Energy Policy, 34(4), 481-488.

Duffy, P. B., Brando, P., Asner, G. P., \& Field, C. B. 2015. Projections of future meteorological drought and wet periods in the Amazon. Proceedings of the National Academy of Sciences, 112(43), 13172-13177.

Durigan, G., Guerin, N., \& da Costa, J. N. M. N. 2013. Ecological restoration of Xingu Basin 
headwaters: motivations, engagement, challenges and perspectives. Philosophical Transactions of the Royal Society B: Biological Sciences, 368(1619), 20120165.

Farella, N., Lucotte, M., Louchouarn, P., \& Roulet, M. 2001. Deforestation modifying terrestrial organic transport in the Rio Tapajos, Brazilian Amazon. Organic Geochemistry, 32(12), 1443-1458.

Gloor, M. R. J. W., Brienen, R. J., Galbraith, D., Feldpausch, T. R., Schöngart, J., Guyot, J. L., ... \& Phillips, O. L. 2013. Intensification of the Amazon hydrological cycle over the last two decades. Geophysical Research Letters, 40(9), 1729-1733.

Godfrey, B. J. 1992. Migration to the gold-mining frontier in Brazilian Amazonia. Geographical Review, 458-469.

Haywood, A. M., Valdes, P. J., Aze, T., Barlow, N., Burke, A., Dolan, A. M., ... \& Salzmann, U. 2019. What can Palaeoclimate Modelling do for you? Earth Systems and Environment, 3(1), 1-18.

Latrubesse, E. M., Arima, E. Y., Dunne, T., Park, E., Baker, V. R., d’Horta, F. M., et al., 2017. Damming the rivers of the Amazon basin. Nature, 546(7658), 363.

Malhi, Y., Roberts, J. T., Betts, R. A., Killeen, T. J., Li, W., \& Nobre, C. A. 2008. Climate change, deforestation, and the fate of the Amazon. science, 319(5860), 169-172.

Marengo, J. A., \& Espinoza, J. C. 2015. Extreme seasonal droughts and floods in Amazonia: causes, trends and impacts. International Journal of Climatology, 36(3), 1033-1050.

Nobre, C. A., Sampaio, G., Borma, L. S., Castilla-Rubio, J. C., Silva, J. S., \& Cardoso, M. 2016. Land-use and climate change risks in the Amazon and the need of a novel sustainable development paradigm. Proceedings of the National Academy of Sciences, 113(39), 10759-10768.

Tranvik, L. J., Downing, J. A., Cotner, J. B., Loiselle, S. A., Striegl, R. G., Ballatore, T. J., ... \& Kortelainen, P. L. 2009. Lakes and reservoirs as regulators of carbon cycling and climate. Limnology and oceanography, 54(6part2), 2298-2314.

Zemp, D. C., Schleussner, C. F., Barbosa, H. M., Hirota, M., Montade, V., Sampaio, G., ... \& 
Rammig, A. 2017. Self-amplified Amazon forest loss due to vegetation-atmosphere feedbacks. Nature communications, 8, 14681. 
APPENDIX I - SUPPLEMENTARY MATERIAL: SPATIOTEMPORAL VARIATIONS OF RIVERINE DISCHARGE WITHIN THE AMAZON BASIN DURING THE LATE HOLOCENE COINCIDE WITH EXTRATROPICAL TEMPERATURE ANOMALIES 


\section{Supplementary material for Spatiotemporal variations of riverine discharge within the Amazon Basin during the late Holocene coincide with extratropical temperature anomalies}

\section{Introduction}

Figures S1, S2, and S13 utilize data from previous literature, references are presented in the captions. The original data that support Figures S3 to S12 and Table S1 and S2 were obtained using methods and materials described in the main paper.

\section{Text S1.}

Additional details of materials and methods are presented below:

\section{Age model:}

Absolute ages were calibrated with OxCal version 4.3 using the IntCal13 calibration curve (Reimer et al., 2013). The age models were produced using the R script BACON version 2.2 (Blaauw \& Christen, 2011) with acc.mean set to 10 and default parameters (Figures S3 and S4). All proxy data were plotted using the weighted mean values obtained from the age models.

We highlight that radiocarbon ages obtained from bulk organic fraction are subject to deviations from the real deposition ages (Björck and Wohlfarth, 2001). However, the relatively young ages of samples close to the core tops suggest that the incorporation of preaged material is not critical to our interpretations. Additionally, since organic material reaching XC-01-2 and XC-03 sites is mostly sourced from different areas, synchronous anomalies in the sediment cores suggest that incorporation of refractory organic matter was not problematic in this case. These considerations are also reinforced by the relatively young suspended organic matter and rapid carbon turnover in rivers from Lowland Amazonia (Hedges et al., 1986; Mayorga et al., 2005). The studied floodplain lake sediments in core $\mathrm{XC}-01-2$ cover a sand layer, with upper portion deposited at $4318 \pm 278$ years ( $84 \mathrm{~cm}$ depth) as determined by optically stimulated luminescence (OSL) dating of quartz (Sawakuchi et al., 2015). This maximum age constraint also supports a late Holocene timespan for the studied core.

\section{Lipids extraction:}

Lipids were extracted using an ASE200 accelerated solvent extractor with a 9:1 dichloromethane (DCM): methanol $(\mathrm{MeOH})$ mixture at $1000 \mathrm{psi}$ and $100{ }^{\circ} \mathrm{C}$ for three five86 
minute cycles Squalene was added as internal standard prior to extraction. The lipid extracts were subsequently rotary-evaporated and dried. To remove wax esters, extracts were saponified using $0.1 \mathrm{M} \mathrm{KOH}$ in $\mathrm{MeOH}$ solution at $80{ }^{\circ} \mathrm{C}$ for $2 \mathrm{~h}$. The neutral fraction was obtained by partitioning with hexane. The n-alkane, ketone and polar fractions were obtained by column-chromatography with deactivated silica $\left(1 \% \mathrm{H}_{2} \mathrm{O}\right)$ and elution with hexane, DCM and a 1:1 DCM: MeOH mixture, respectively. To remove unsaturated compounds, the nalkane fraction was eluted with hexane over $4 \mathrm{~cm}$ of $\mathrm{AgNO}_{3}$-coated $\mathrm{SiO}_{2}$.

The average chain length $\left(\mathrm{ACL}_{27-33}\right)$ of $n$-alkanes was calculated using the following formula:

$$
A C L_{27-33}=\frac{27 \cdot n C_{27}+29 \cdot n C_{29}+31 \cdot n C_{31}+33 \cdot n C_{33}}{n C_{27}+n C_{29}+n C_{31}+n C_{33}}
$$

(1)

The carbon preference index $\left(\mathrm{CPI}_{25-33}\right)$ was calculated through equation (2):

$$
C P I_{27-33}=0.5 \cdot\left(\frac{n C_{27}+n C_{29}+n C_{31}+n C_{33}}{n C_{26}+n C_{28}+n C_{30}+n C_{32}}+\frac{n C_{27}+n C_{29}+n C_{31}+n C_{33}}{n C_{28}+n C_{30}+n C_{32}+n C_{34}}\right)
$$
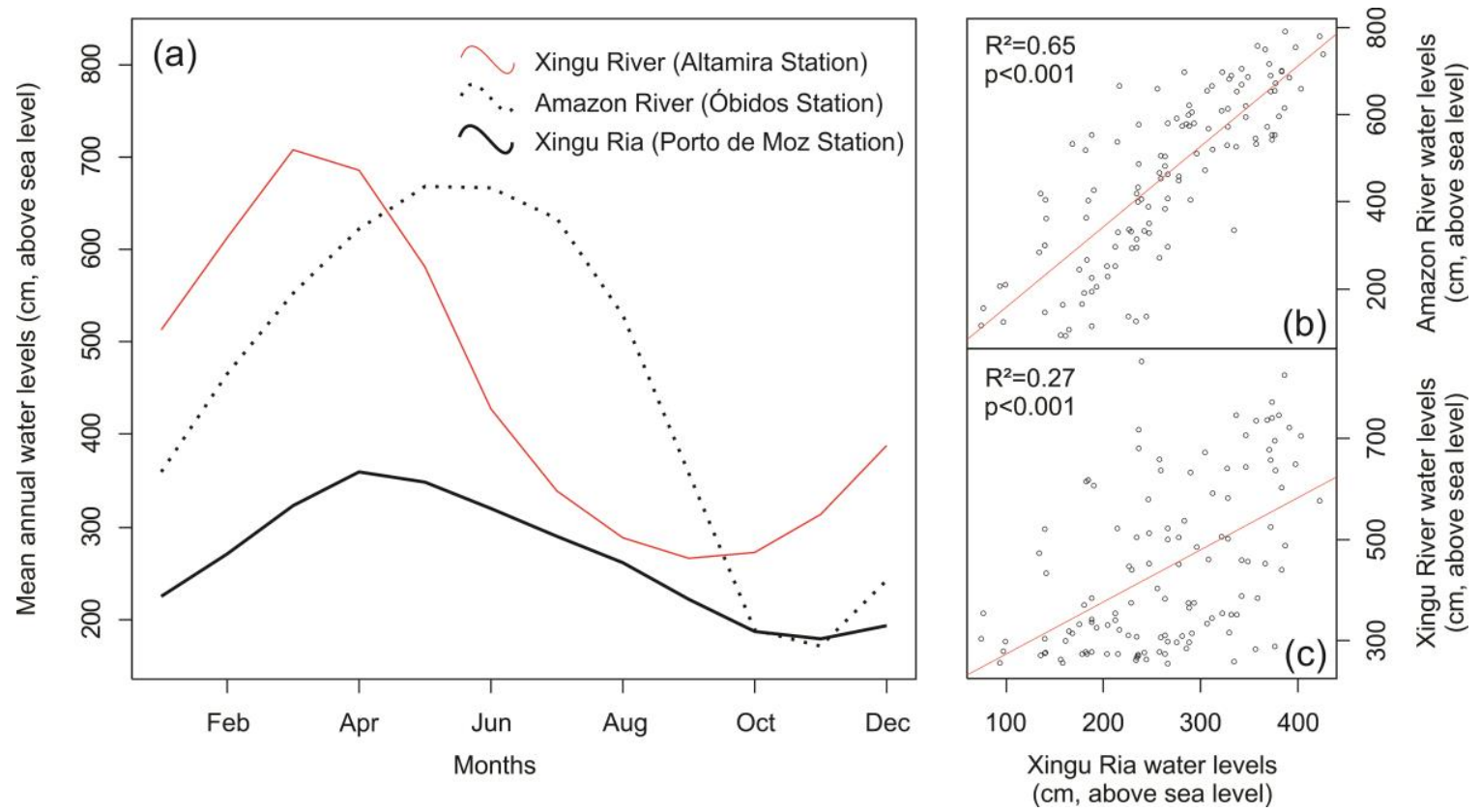

Figure S1 - Mean annual water levels of the Amazon and Xingu rivers calculated from data collected at Óbidos, Altamira and Porto de Moz stations between 1979 and 1990 (a) (ANA, 2017). Monthly water levels at the Porto de Moz station, near the Amazon-Xingu confluence, were compared to correspondent stages in these rivers and show a stronger influence of the Amazon River levels in the Xingu Ria (b, c) (ANA, 2017). 

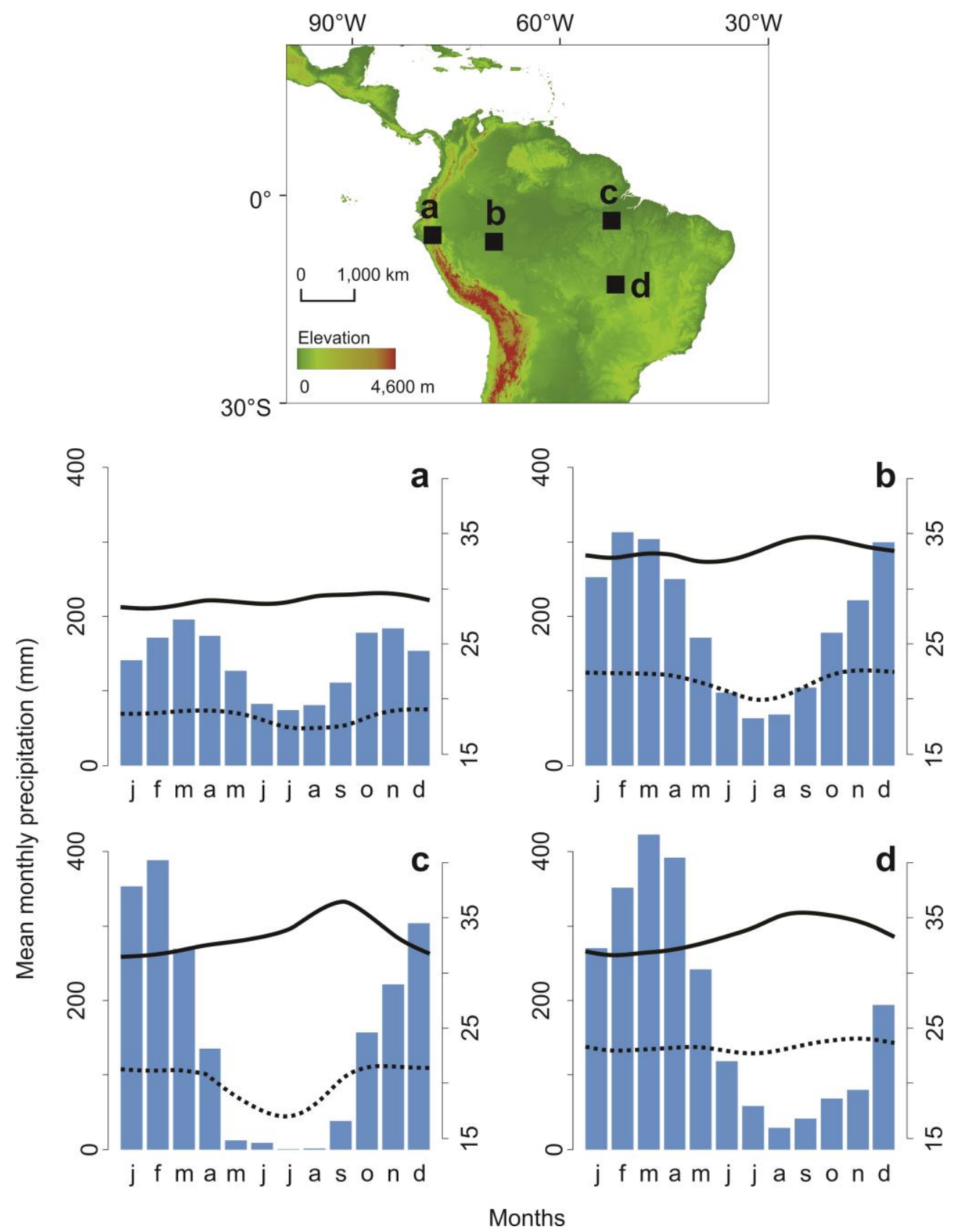

Figure S2 - Mean monthly precipitation (mm) and maximum (solid) and minimum (dashed) average temperatures $\left({ }^{\circ} \mathrm{C}\right)$ from Amazonia meteorological stations. Based on 2003-2013 climatology data obtained from INMET (2019) and SENAMHI (2019): (a) Naranjillo Station (882 m asl); (b) Eirunepe Station (104 m asl); (c) Altamira station (74 m asl); (d) Canarana station (430 m asl). 


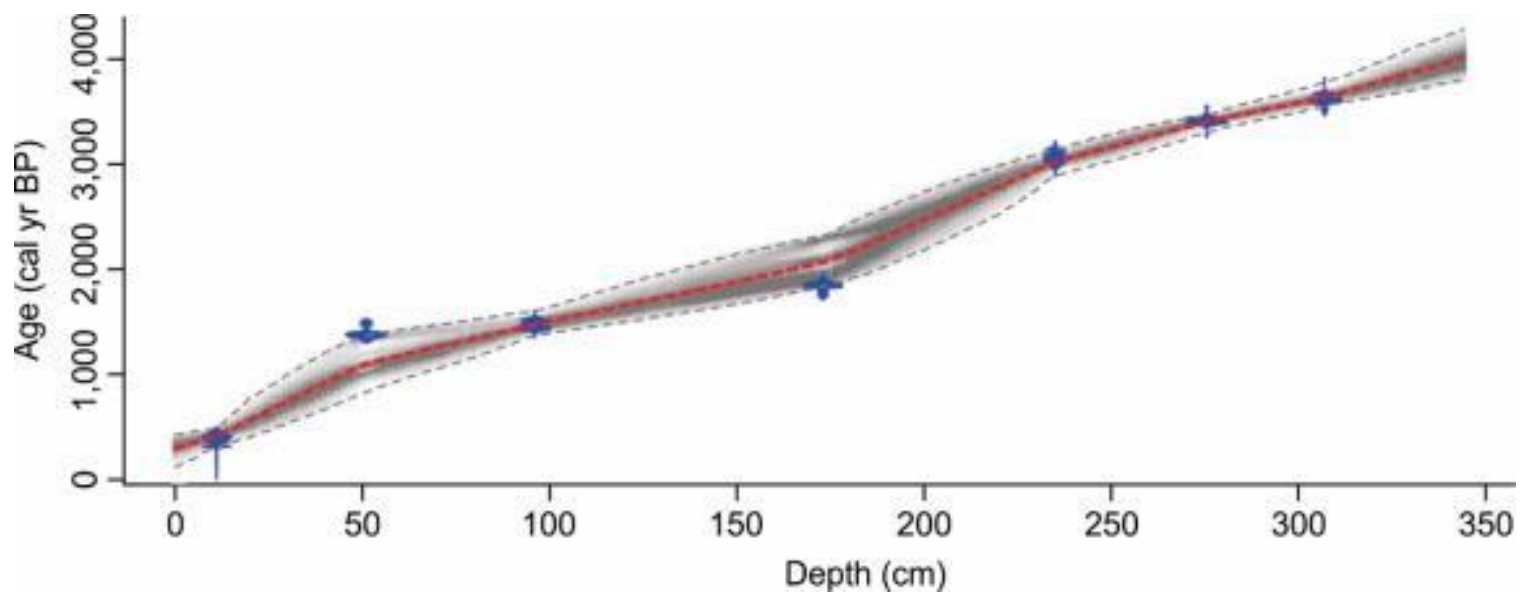

Figure S3- Age-depth model of core XC-03 based on seven bulk sediment ${ }^{14} \mathrm{C}$ ages calibrated with the IntCal13 curve (Reimer et al., 2013) and plotted with the R script BACON version 2.2 (Blaauw \& Christen, 2011). Red dashed line shows the calculated mean age and grey dashed lines represent the $95 \%$ confidence interval. Further information regarding the ${ }^{14} \mathrm{C}$ ages is presented in Table $\mathrm{S} 1$.

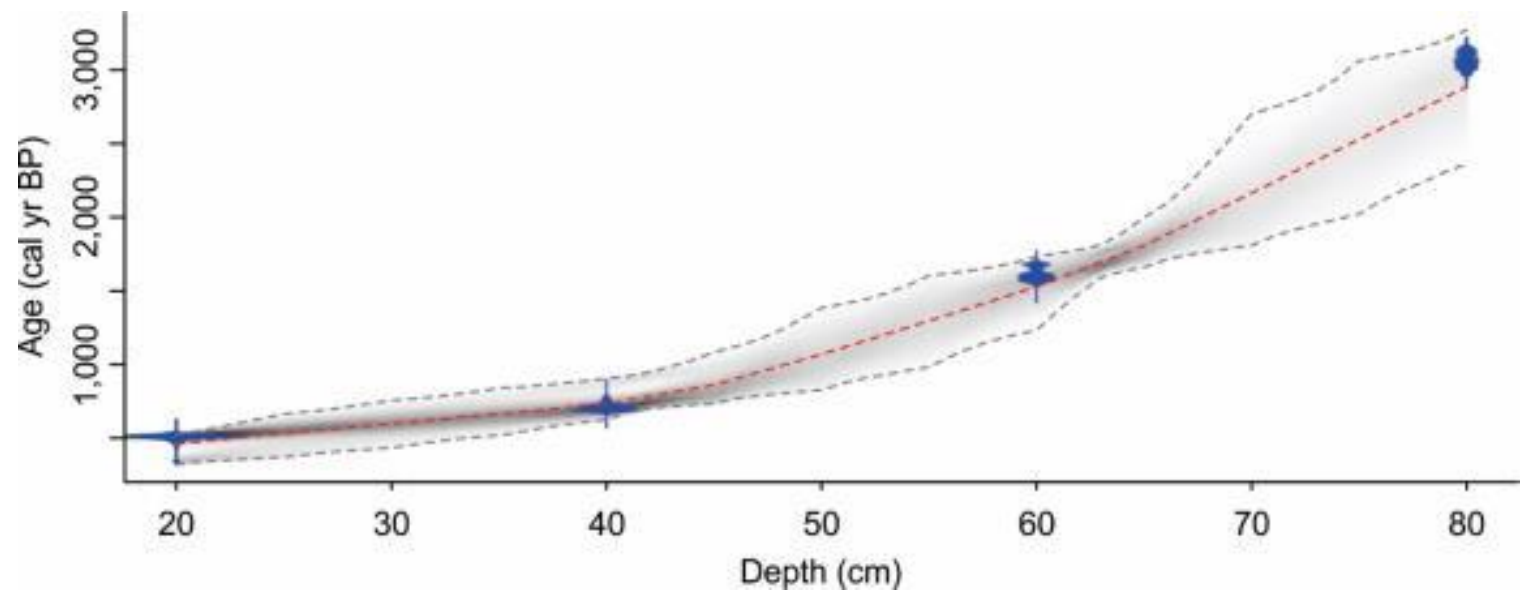

Figure S4 - Age-depth model of core XC-01-2 based on four bulk sediment ${ }^{14} \mathrm{C}$ ages calibrated with the IntCal13 curve (Reimer et al., 2013) and plotted with the R script BACON version 2.2 (Blaauw \& Christen, 2011). Red dashed line shows the calculated mean age and grey dashed lines represent the $95 \%$ confidence interval. Further information regarding the ${ }^{14} \mathrm{C}$ ages is presented in Table S2. 

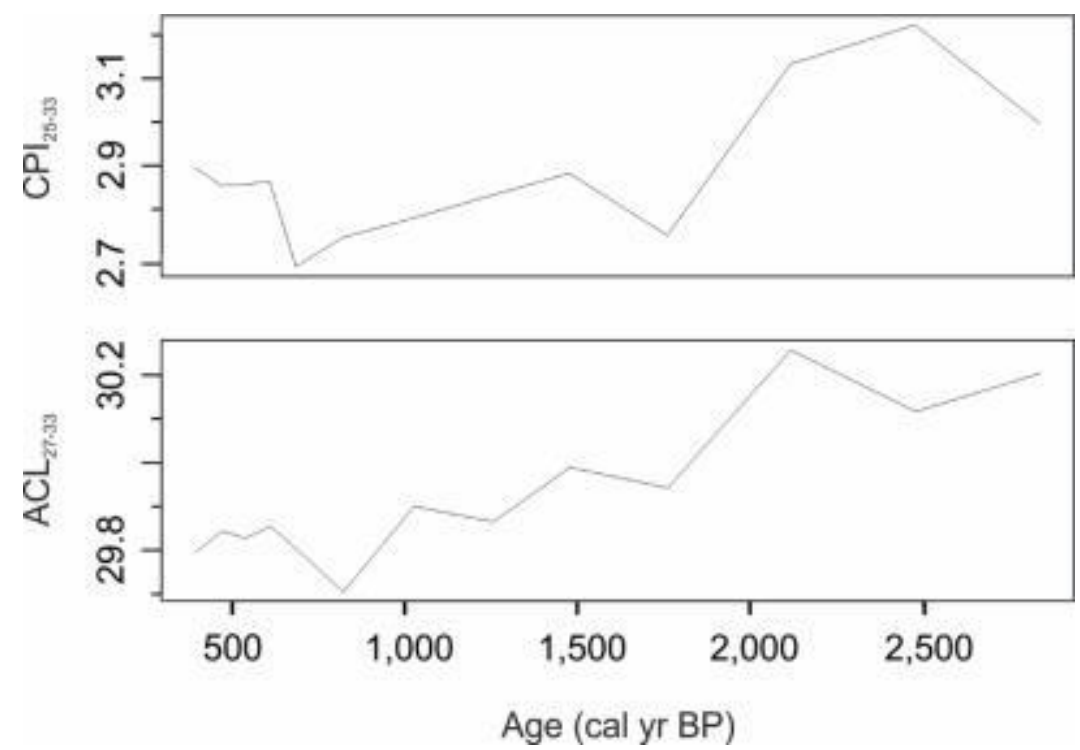

Figure S5 - Variation of carbon preference index $\left(\mathrm{CPI}_{25-33}\right)$ and average chain lengths $\left(\mathrm{ACL}_{27-33}\right)$ in core $\mathrm{XC}-01$ 2.
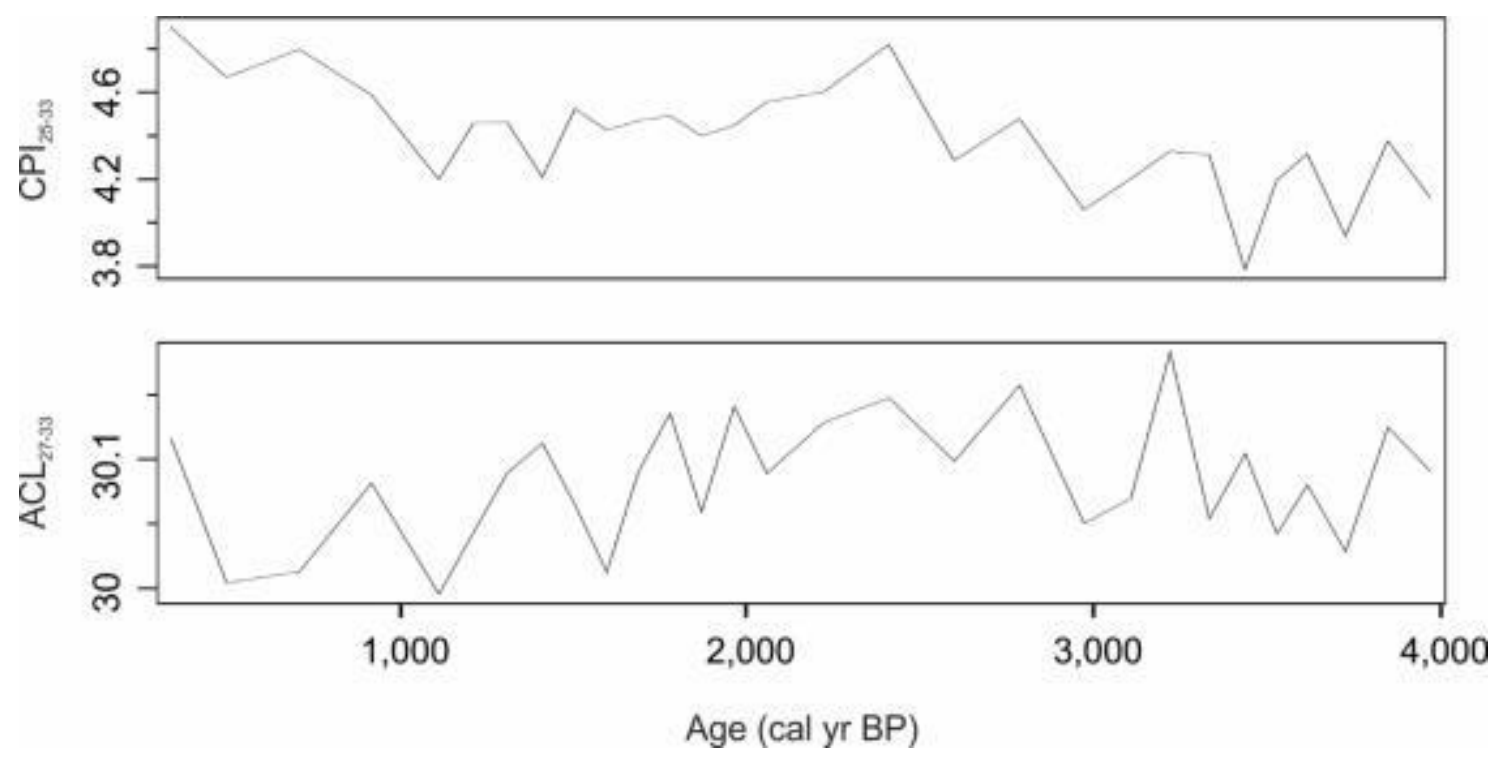

Figure S6 -Variation of carbon preference index $\left(\mathrm{CPI}_{25-33}\right)$ and average chain lengths $\left(\mathrm{ACL}_{27-33}\right)$ in core $\mathrm{XC}-03$. 


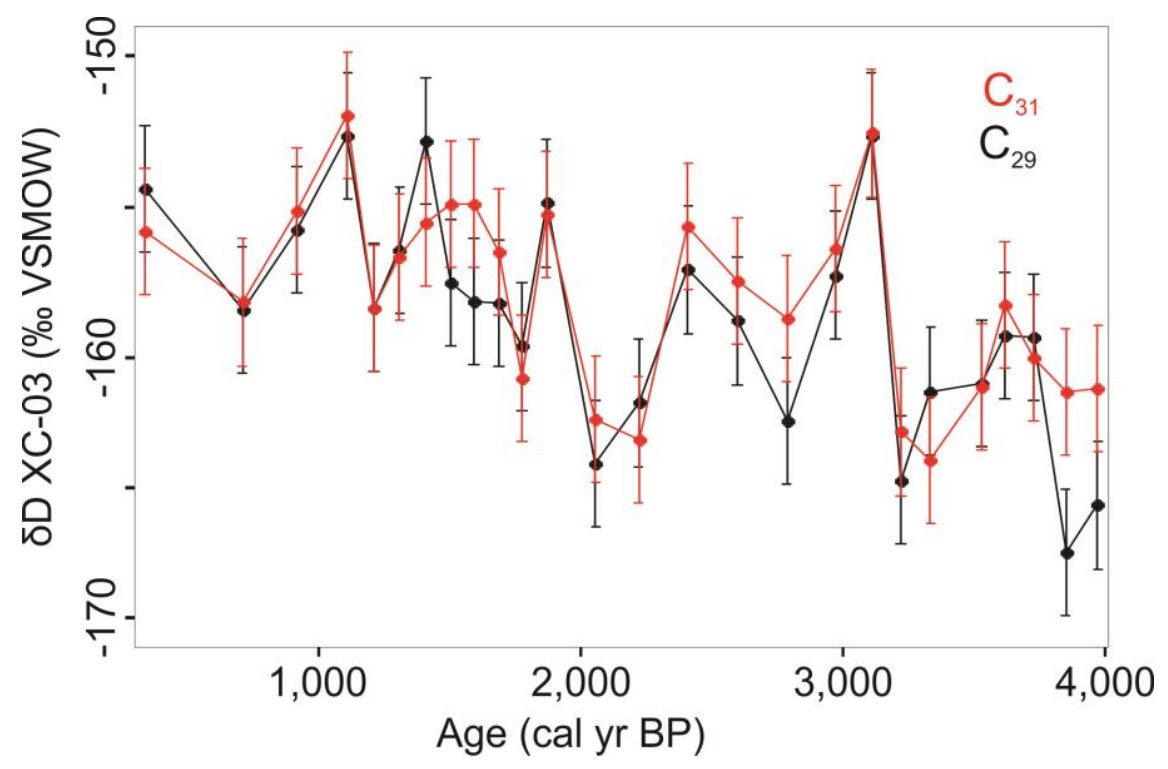

Figure S7 - Variation of $\delta \mathrm{D}$ in $\mathrm{C}_{29}$ and $\mathrm{C}_{31}$ of $n$-alkanes in core XC-03. Given the similar behavior, results are presented as the weighted average of the two compounds $\left(\delta \mathrm{D}_{29-31}\right)$.

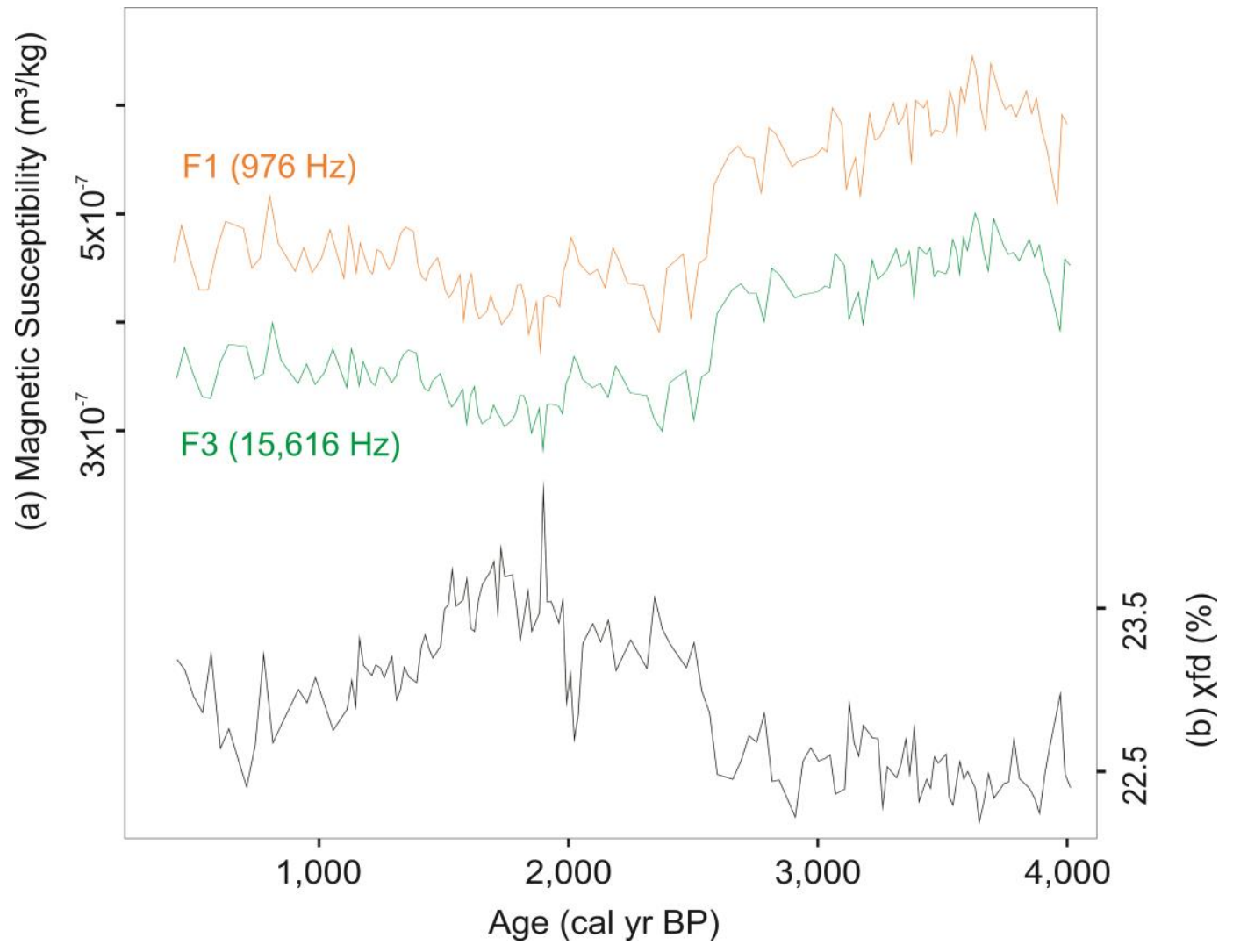

Figure S8 - Profiles of low- and high-frequency susceptibility measurements (a) and calculated frequencydependent susceptibility (b) ( $\chi \mathrm{fd}$ ) of core XC-03. 


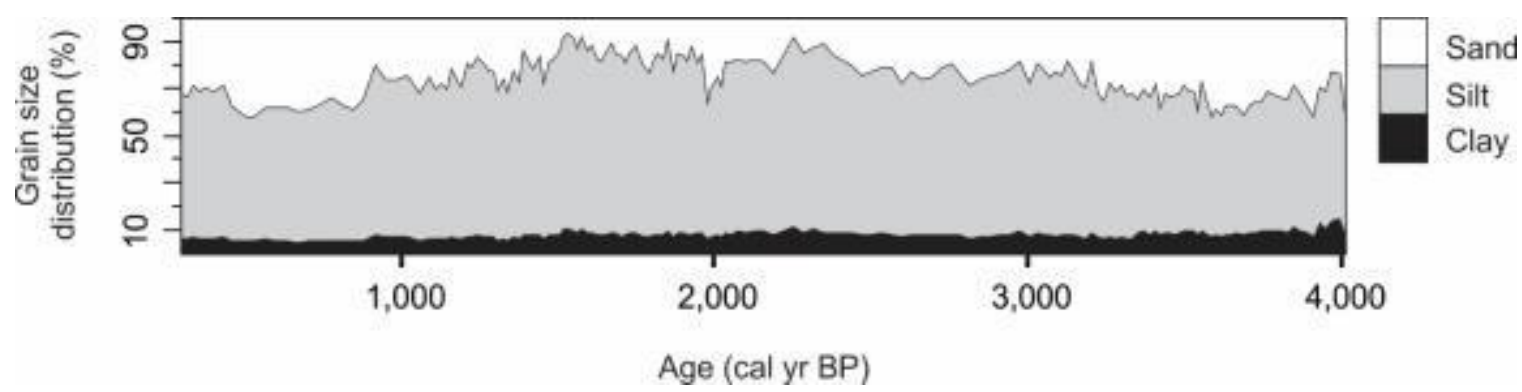

Figure S9 - Variation of grain size in core XC-03. Clay fraction corresponds to particles finer than $3.9 \mu \mathrm{m}$, silt fraction corresponds to particles with size between 3.9 and $62.5 \mu \mathrm{m}$, and sand to particles with size between 62.5 $\mu \mathrm{m}$ and $2 \mathrm{~mm}$. 

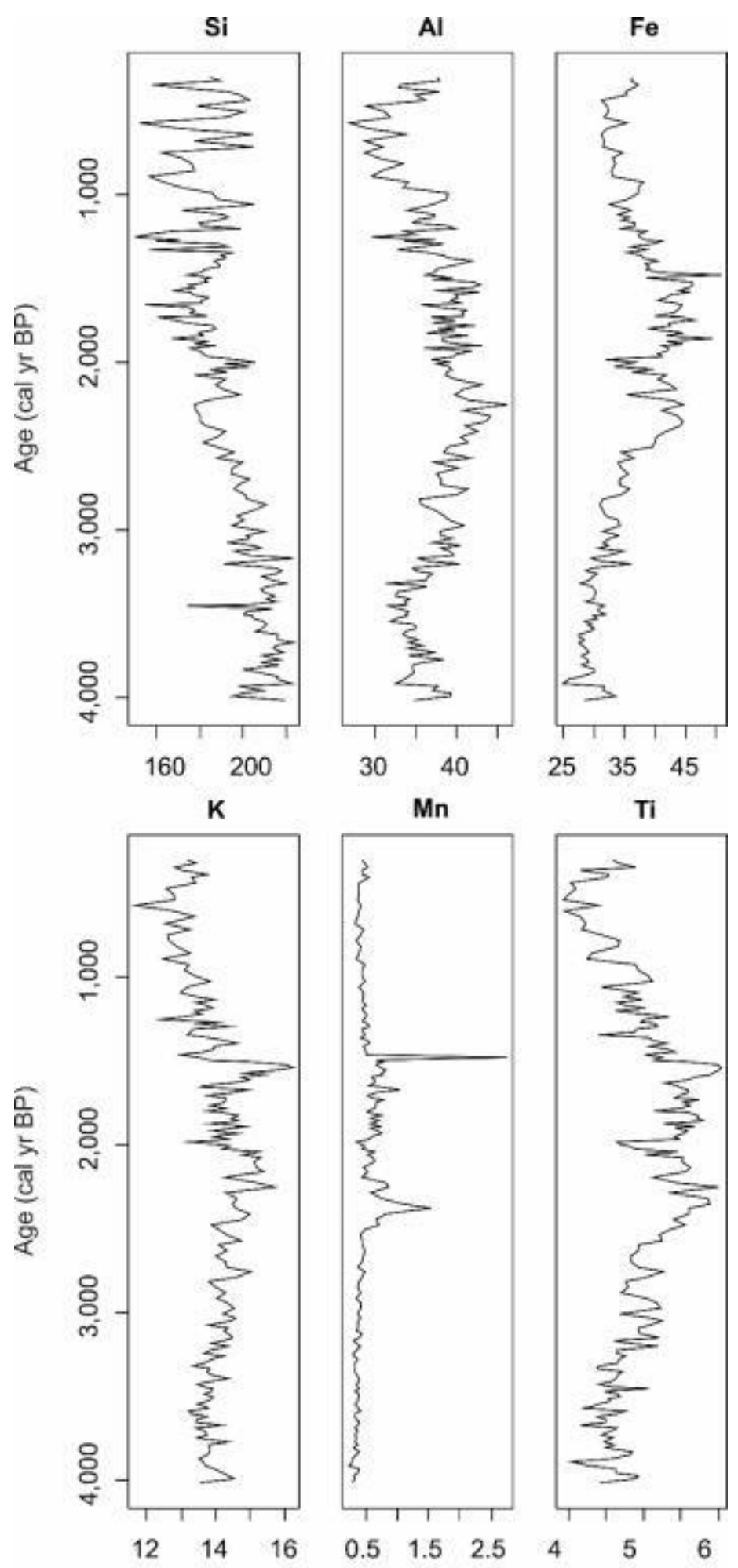

Major elements distribution $(\mathrm{g} / \mathrm{kg})$

Figure S10 - Variation of major elements distributions in sediment core XC-03 obtained from XRF measurements. 

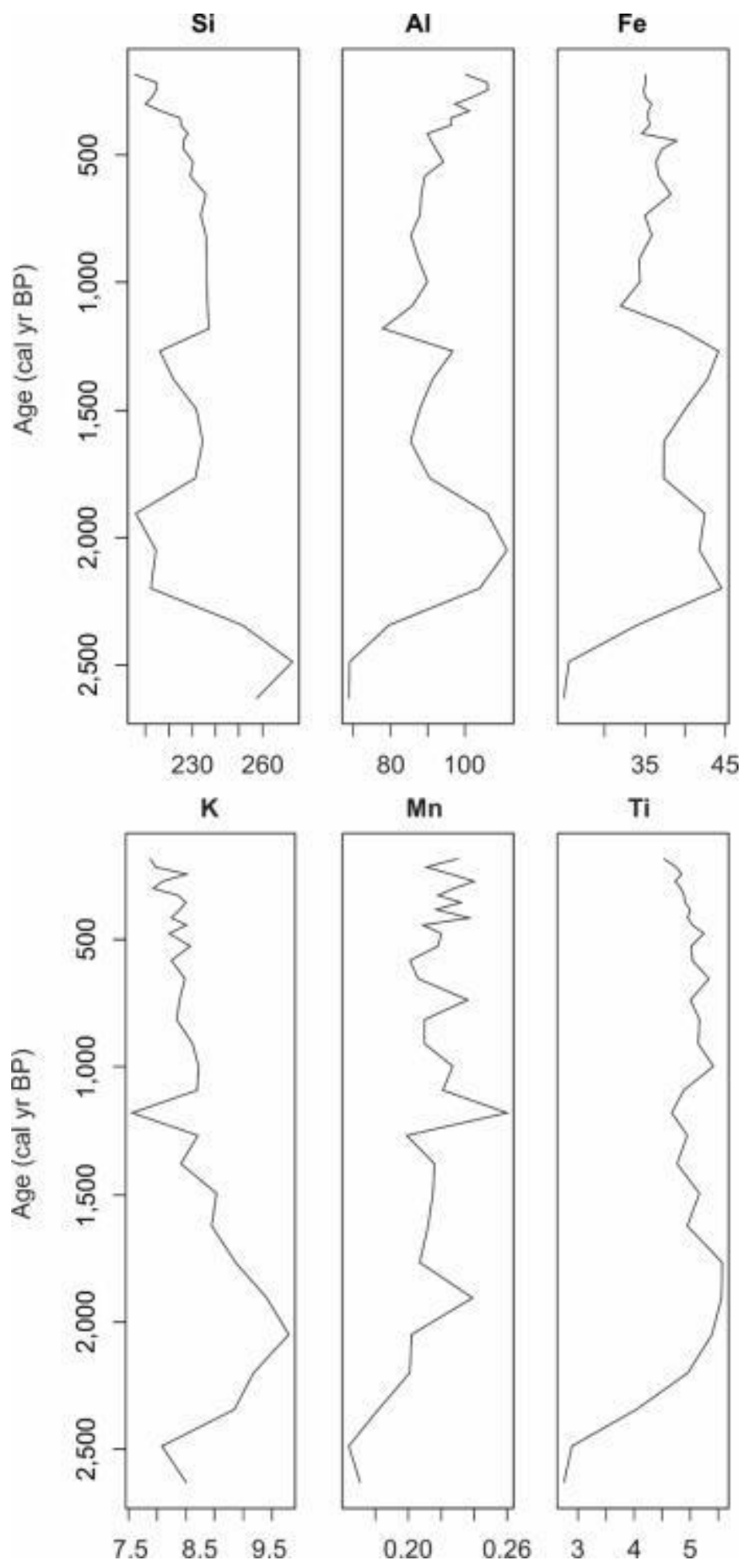

Figure S11 - Variation of major elements distributions in sediment core XC-01-2 obtained from XRF measurements. 


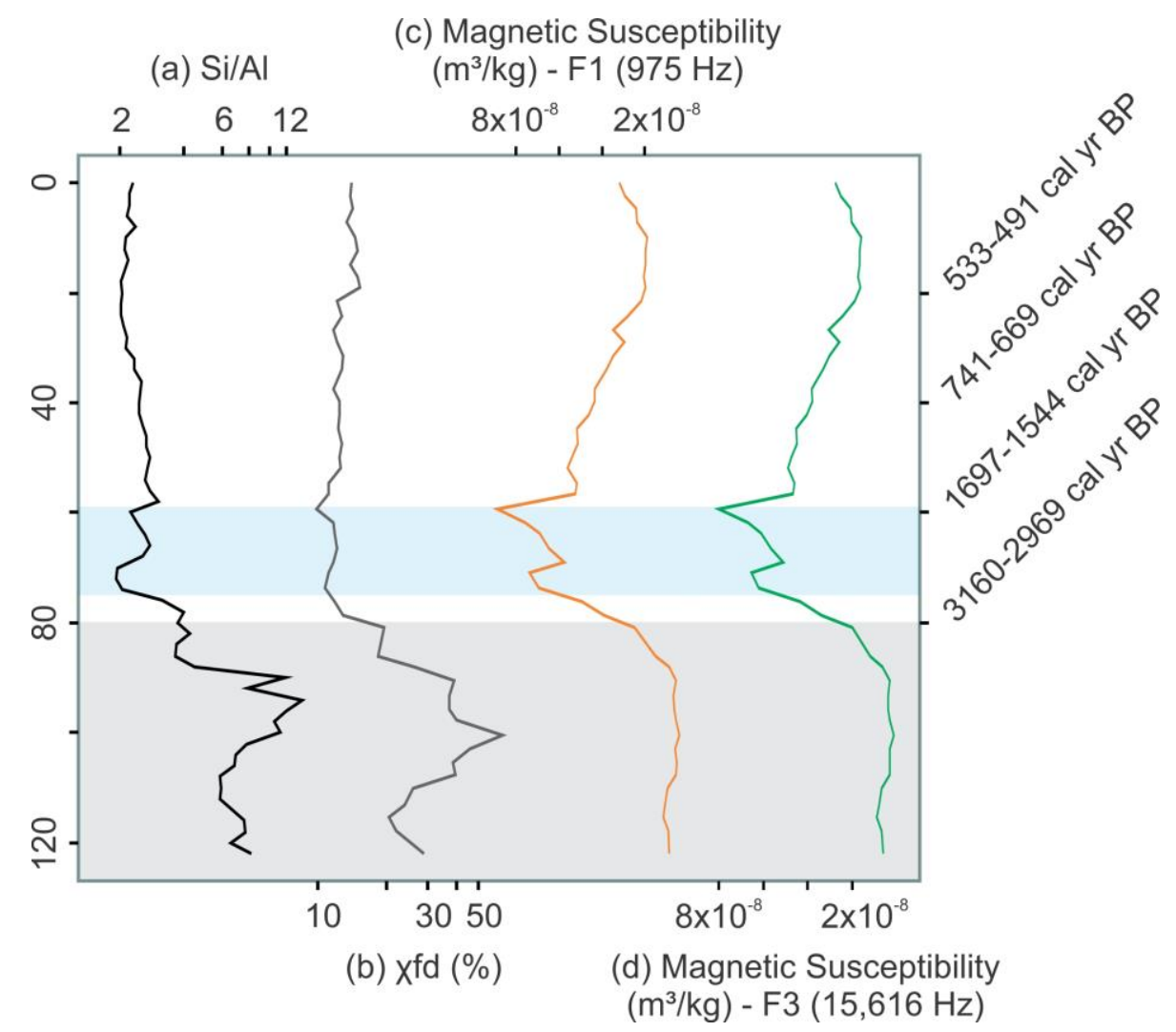

Figure S12 - Comparison of $\mathrm{Si} / \mathrm{Al}$ (a), $\chi \mathrm{fd} \%$ (b), and magnetic susceptibility results (c-d) from core XC-01-2 (0$120 \mathrm{~cm}$ ). Grey-shaded area indicates the section outside of the age model and blue-shaded area highlights the interval from 2,600 to1,400 cal yr BP. 


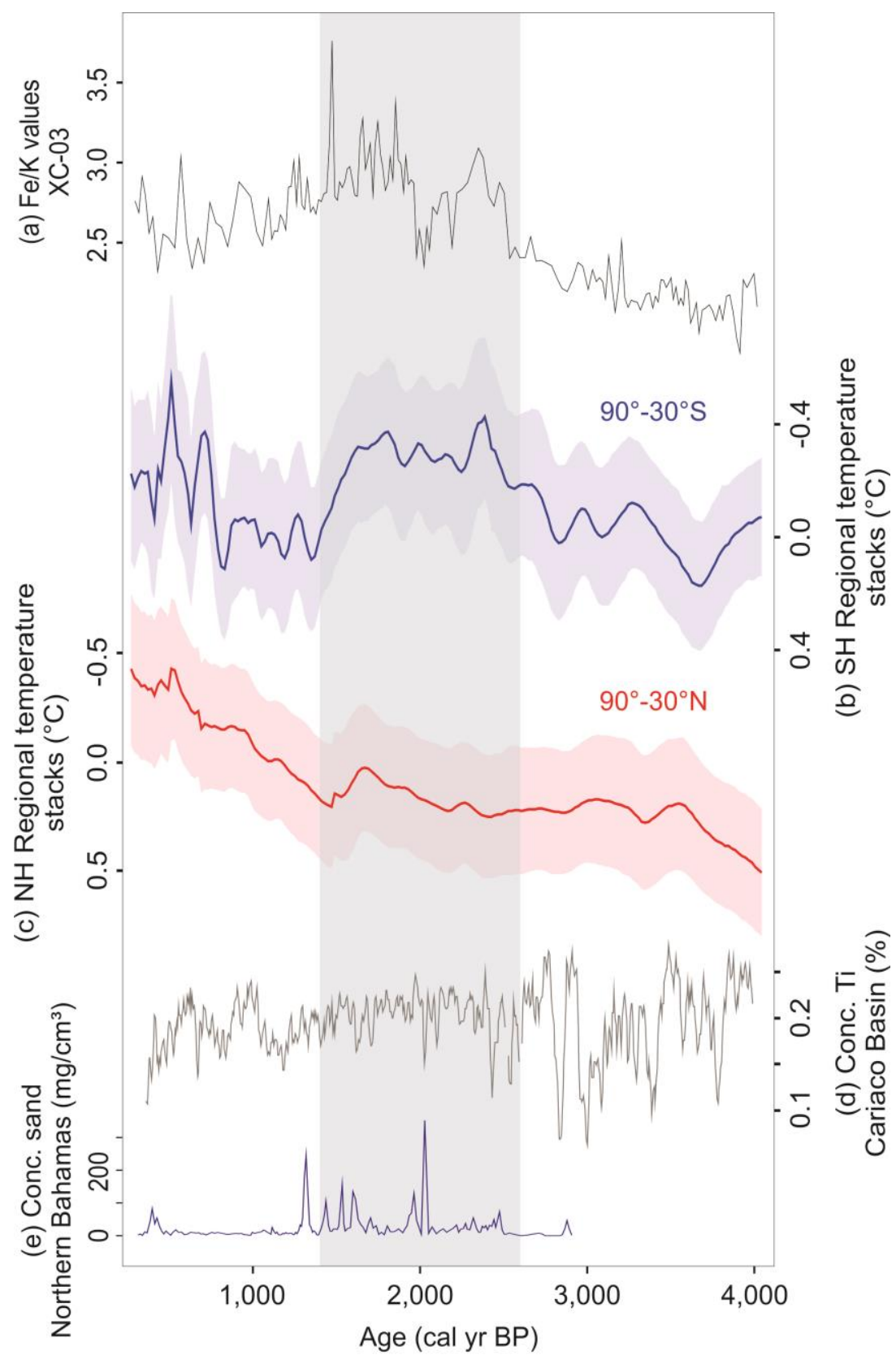

Figure S13 - XC-03 Fe/K record (a) compared to a reconstruction of regional temperature stacks of extratropical areas of the Northern and Southern Hemispheres (b) (Marcott et al., 2013) and to proxies from literature (c-d). (c) Sand concentration in a core collected in the Abaco Island, northern Bahamas (van Hengstum et al., 2016), higher concentrations of sand indicate increased occurrence of intense hurricanes. (d) Titanium concentrations in sediments of the Cariaco Basin (Haug et al. 2001), where higher Ti proportions indicate greater terrigenous input and a northern mean position of the ITCZ. Grey-shaded area highlights the interval from 2,600 to 1,400 cal yr BP. Purple and red-shaded areas shaded areas represent the $2 \sigma$ uncertainty envelope calculated by Marcott et al., 2013). 


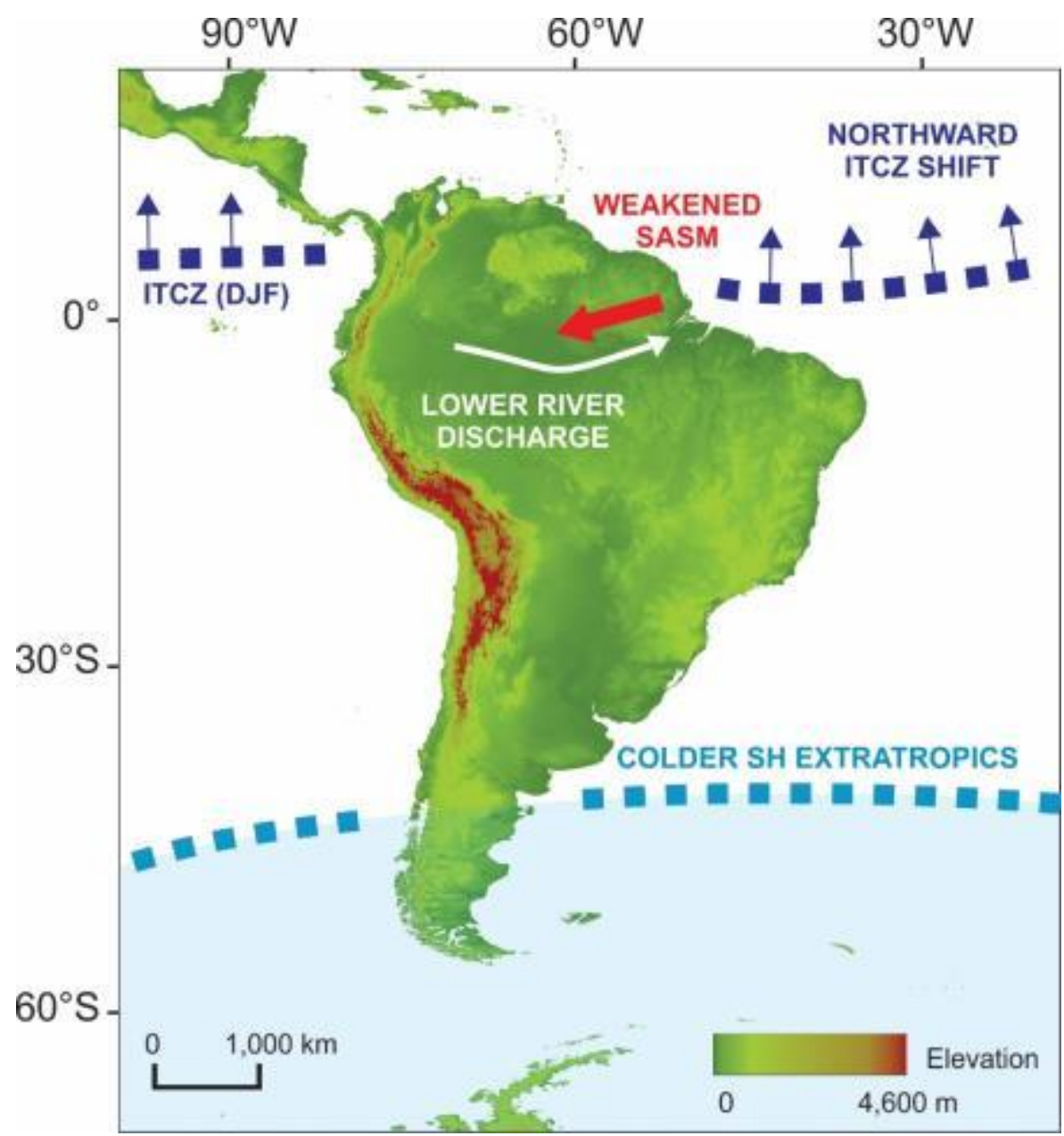

Figure S14 - Simplified schematic of the response of the Amazon River water discharge to extratropical thermal forcing. Colder sea-surface temperatures in the southern extratropics from about 2,400 to 1,600 cal yr BP possibly promoted an ocean heat transport anomaly that affected atmospheric energy fluxes. The southward cross-equatorial atmospheric energy flux, in turn, moved the ITCZ northward. Detailed explanations of the energy-flux framework and teleconnections of extratropical temperatures and tropical precipitation are presented in Kang (2009), Chiang \& Friedman (2012), and Schneider et al. (2014). 
Table S1 - Raw ${ }^{14} \mathrm{C}$ and calibrated ages of bulk organic carbon from core XC-03. Absolute ages were calibrated with OxCal version 4.3 using the IntCal13 calibration curve (Reimer et al., 2013).

\begin{tabular}{llll}
\hline Lab. ID & $\begin{array}{l}\text { Depth } \\
(\mathrm{cm})\end{array}$ & $\begin{array}{l}\text { Conventional age } \\
(\mathrm{yr} \mathrm{BP})\end{array}$ & $\begin{array}{l}\text { Calibrated ages } \\
(\text { cal yr BP, } \sigma)\end{array}$ \\
\hline Beta-454410 & 11 & $310 \pm 30$ & $465-301$ \\
\hline Beta-458502 & 51 & $1500 \pm 30$ & $1518-1312$ \\
\hline Beta-454412 & 96 & $1590 \pm 30$ & $1545-1409$ \\
\hline Beta-472434 & 173 & $1900 \pm 30$ & $1922-1737$ \\
\hline Beta-458504 & 235 & $2920 \pm 30$ & $3160-2969$ \\
\hline Beta-454414 & 275 & $3190 \pm 30$ & $3463-3361$ \\
\hline Beta-458505 & 307 & $3370 \pm 30$ & $3694-3515$ \\
\hline
\end{tabular}

Table S2 - Raw ${ }^{14} \mathrm{C}$ and calibrated ages of bulk organic carbon from core XC-03. Absolute ages were calibrated with OxCal version 4.3 using the IntCal13 calibration curve (Reimer et al., 2013).

\begin{tabular}{llll}
\hline Lab. ID & $\begin{array}{l}\text { Depth } \\
(\mathrm{cm})\end{array}$ & $\begin{array}{l}\text { Conventional age } \\
(\text { yr BP })\end{array}$ & $\begin{array}{l}\text { Calibrated ages } \\
(\text { cal yr BP, 2 })\end{array}$ \\
\hline LACUFF-170081 & 20 & $456 \pm 24$ & $533-491$ \\
\hline Beta-488006 & 40 & $780 \pm 30$ & $741-669$ \\
\hline Beta-488007 & 60 & $1700 \pm 30$ & $1697-1544$ \\
\hline Beta-468959 & 80 & $2920 \pm 30$ & $3160-2969$ \\
\hline
\end{tabular}


APPENDIX II - SUPPLEMENTARY MATERIAL: THE FATE OF CARBON IN SEDIMENTS OF THE XINGU AND TAPAJÓS CLEARWATER RIVERS, EASTERN AMAZON 
Supplementary Material for The fate of carbon in sediments of the Xingu and Tapajós clearwater rivers, eastern Amazon

In the following pages, supplementary data is provided in Table S1 and in Figures S1 to S7. 
Table S1 - Location and data from suspended sediment samples (SS), riverbed sediment samples (RS) and sediment cores (Core) collected from Xingu, Tapajós and Amazon rivers during dry and wet seasons. The type of analyses that were performed for each sample are discriminated in the "Type" section as follows: Major Elements Concentration determined by ICP-OES (ICP); Major Elements concentration determined by XRF spectrometer (XRF); Major elements concentration by XRF, COT concentration, $\delta^{13} \mathrm{C}_{\text {org }}$ analysis and pollen and diatom analysis (CPD); TOC concentration and $\delta^{13} \mathrm{C}_{\text {org }}$ analysis (OC). Major elements

\begin{tabular}{|c|c|c|c|c|c|c|c|c|c|c|c|c|c|c|c|}
\hline Sample & Type & Lat. & Long. & Season & River & $\mathbf{M g}$ & Al & $\mathbf{K}$ & Ca & Ti & Mn & $\mathbf{F e}$ & $\mathbf{P}$ & TOC & $\delta^{13} C_{\text {org }}$ \\
\hline XA 01 & SS - ICP & -3.218 & -52.146 & Dry (Out/2011) & Xingu & 0.17 & 4.13 & 0.50 & 0.27 & 0.13 & 0.22 & 1.65 & 0.788 & na & na \\
\hline XA 19 & SS - ICP & -3.885 & -52.592 & Dry (Out/2011) & Xingu & 0.15 & 3.42 & 0.29 & 0.20 & 0.11 & 0.17 & 1.30 & .631 & na & na \\
\hline XA 23 & SS - ICP & -3.486 & -51.691 & Dry (Out/2011) & Xingu & 0.22 & 7.96 & 0.64 & 0.36 & 0.24 & 0.21 & 2.72 & 0.922 & na & na \\
\hline XA 26 & SS - ICP & -2.646 & -51.980 & Dry (Out/2011) & Xingu & 0.34 & 9.16 & 1.00 & 0.44 & 0.30 & 0.27 & 3.51 & 0.664 & na & na \\
\hline XA 28 & SS - ICP & -3.007 & -51.852 & Dry (Out/2011) & Xingu & 0.12 & 3.46 & 0.30 & 0.18 & 0.11 & 0.11 & 1.36 & 0.578 & na & na \\
\hline XA 32 & SS - ICP & -1.444 & -52.235 & Dry (Out/2011) & Xingu & 0.78 & 9.70 & 2.05 & 0.62 & 0.46 & 0.18 & 4.81 & 687 & na & na \\
\hline XA 39 & SS - ICP & -3.221 & -52.139 & Wet (May/2012) & Xingu & 0.10 & 2.81 & 0.11 & 0.15 & 0.10 & 0.05 & 1.51 & 0.037 & na & na \\
\hline XA 49A & SS - ICP & -3.401 & -51.973 & Wet (May/2012) & Xingu & 0.06 & 1.75 & 0.05 & 0.07 & 0.05 & 0.04 & 0.92 & 0.029 & na & na \\
\hline XA 53A & SS - ICP & -2.625 & -51.969 & Wet (May/2012) & Xingu & 0.05 & 1.33 & 0.04 & 0.09 & 0.04 & 0.06 & 0.89 & 0.027 & na & na \\
\hline XA 56 & SS - ICP & -1.793 & -52.239 & 【ay/2012) & Xingu & 0.09 & 1.29 & 0.08 & 0.08 & 0.05 & 0.03 & 1.11 & .026 & na & na \\
\hline XA 60 & SS - ICP & -1.498 & -52.308 & Wet (May/2012) & Amazon & 2.13 & 23.34 & 4.68 & 1.55 & 1.08 & 0.16 & 14.65 & 0.270 & na & na \\
\hline XA 73 & SS - ICP & -2.217 & -52.160 & Wet (May/2012) & Xingu & 0.07 & 1.43 & 0.04 & 0.07 & 0.04 & 0.06 & 1.10 & 0.039 & na & na \\
\hline STM 01 & SS - ICP & -1.931 & -55.511 & Wet (May/2012) & Amazon & 2.75 & 27.14 & 6.20 & 2.00 & 1.52 & 0.23 & 16.08 & 0.298 & na & na \\
\hline STM 11 & SS - ICP & -2.425 & -54.917 & Wet (May/2012) & Tapajós & 0.04 & 1.01 & 0.01 & 0.04 & 0.03 & 0.02 & 0.55 & 0.019 & na & na \\
\hline STM 13 & SS - ICP & -2.802 & -55.077 & Wet (May/2012) & Tapajós & 0.05 & 1.83 & 0.02 & 0.04 & 0.05 & 0.03 & 1.00 & 0.031 & na & na \\
\hline STM 19 & SS - ICP & -2.470 & -54.997 & Wet (May/2012) & Tapajós & 0.06 & 2.19 & 0.07 & 0.12 & 0.05 & 0.04 & 1.42 & 0.045 & na & na \\
\hline STM 22 & SS - ICP & -2.450 & -54.528 & Wet (May/2012) & Amazon & 1.84 & 19.80 & 4.16 & 1.34 & 0.99 & 0.14 & 12.47 & 0.239 & na & na \\
\hline STM 24 & SS - ICP & -2.809 & -55.070 & Dry (Nov/2012) & Tapajós & 0.15 & 2.64 & 0.11 & 0.21 & 0.07 & 0.07 & 0.85 & 0.039 & na & na \\
\hline STM 33 & SS - ICP & -3.590 & -55.331 & Dry (Nov/2012) & Tapajós & 0.10 & 4.05 & 0.13 & 0.11 & 0.10 & 0.10 & 1.12 & 0.042 & na & na \\
\hline STM 37 & SS - ICP & -2.471 & -54.992 & Dry (Nov/2012) & Tapajós & 0.06 & 1.76 & 0.04 & 0.10 & 0.05 & 0.18 & 0.67 & 0.057 & na & na \\
\hline STM 39 & SS - ICP & -2.427 & -54.936 & Dry (Nov/2012) & Tapajós & 0.05 & 1.03 & 0.04 & 0.10 & 0.03 & 0.13 & 0.41 & 0.044 & na & na \\
\hline STM 51 & SS - ICP & -2.157 & -55.186 & Dry (Nov/2012) & Amazon & 0.40 & 4.73 & 0.67 & 0.34 & 0.17 & 0.03 & 2.23 & 0.048 & na & na \\
\hline STM 60 & SS - ICP & -2.450 & -54.531 & Dry (Nov/2012) & Amazon & 0.51 & 6.20 & 0.95 & 0.41 & 0.24 & 0.04 & 2.76 & 0.053 & na & na \\
\hline XA 49B & $\mathrm{RS}-\mathrm{XRF}$ & -3.401 & -51.973 & Wet (May/2012) & Xingu & 701 & 58640 & 5139 & 2009 & 1893 & 75.6 & 6482 & na & 0.64 & -28.59 \\
\hline XA 53B & $\mathrm{RS}-\mathrm{XRF}$ & -2.625 & -51.969 & Wet (May/2012) & Xingu & 916 & 82927 & 6289 & 2825 & 3056 & 498 & 41523 & na & 3.33 & -28.48 \\
\hline XA 55 & $\mathrm{RS}-\mathrm{XRF}$ & -1.803 & -52.252 & Wet (May/2012) & Xingu & 4015 & 64939 & 12587 & 5159 & 3327 & 215 & 20289 & na & 1.74 & -29.53 \\
\hline XA 58 & $\mathrm{RS}-\mathrm{XRF}$ & -1.544 & -52.287 & Wet (May/2012) & Amazon & 6038 & 74044 & 15670 & 5713 & 4508 & 540 & 30488 & na & 0.66 & -27.49 \\
\hline XA 59 & RS - XRF & -1.496 & -52.309 & Wet $(\mathrm{N}$ & Amazon & 5710 & 70042 & 15778 & 5836 & 4207 & 369 & 24462 & na & 0.65 & -28.07 \\
\hline XA 64 & RS - XRF & -1.471 & -52.243 & Wet (May/2012) & Amazon & 6129 & 68559 & 15128 & 6490 & 4219 & 441 & 25534 & na & 0.55 & -27.61 \\
\hline
\end{tabular}




\begin{tabular}{|c|c|c|c|c|c|c|c|c|c|c|c|c|c|c|c|}
\hline Sample & Type & Lat. & Long. & Season & River & Mg & Al & $\mathbf{K}$ & $\mathbf{C a}$ & $\mathbf{T i}$ & Mn & $\mathbf{F e}$ & $\mathbf{P}$ & TOC & $\delta^{13} C_{\text {org }}$ \\
\hline XA 66 & RS - XRF & -1.502 & -52.219 & Wet (May/2012) & Amazon & 6065 & 78082 & 15516 & 4833 & 4677 & 261 & 21945 & na & 0.50 & -29.00 \\
\hline XA 76A & RS - XRF & -2.462 & -52.097 & Wet (May/2012) & Xingu & 557 & 96236 & 5354 & 2788 & 4200 & 532 & 39701 & na & 3.28 & -27.98 \\
\hline STM 02 & RS - XRF & -1.933 & -55.494 & Wet (May/2012) & Amazon & 5133 & 59336 & 12790 & 6369 & 4247 & 306 & 19137 & na & 0.26 & na \\
\hline STM 06A & RS - XRF & -2.140 & -55.012 & Wet (May/2012) & Amazon & 6405 & 74871 & 16129 & 6403 & 4278 & 519 & 28761 & na & 0.66 & -27.99 \\
\hline STM 10 & RS - XRF & -2.359 & -54.912 & Wet (May/2012) & Tapajós & 5803 & 75582 & 16503 & 5490 & 4749 & 409 & 30149 & na & na & na \\
\hline STM 12 & RS - XRF & -2.798 & -55.166 & Wet (May/2012) & Tapajós & na & 34307 & 1041 & 1694 & 1474 & 43.5 & 2585 & na & 0.20 & na \\
\hline STM 20 & RS - XRF & -2.446 & -54.549 & Wet (May/2012) & Amazon & 6584 & 70810 & 15418 & 6263 & 4429 & 632 & 31308 & na & 0.84 & -27.98 \\
\hline XA 25 & RS - CPD & -2.645 & -51.970 & Dry (Oct/2011) & Xingu & na & na & na & na & na & na & na & na & 3.82 & -29.36 \\
\hline XA 30 & RS - CPD & -1.688 & -52.243 & Dry (Oct/2011) & Xingu & na & na & na & na & na & na & na & na & 0.83 & -27.85 \\
\hline XA 31 & RS - CPD & -1.789 & -52.249 & Dry (Oct/2011) & Xingu & na & na & na & na & na & na & na & na & 1.11 & -28.38 \\
\hline XA 33 & RS - CPD & -1.790 & -52.254 & Dry (Oct/2011) & Xingu & na & na & na & na & na & na & na & na & 1.91 & -28.28 \\
\hline XA 34 & RS - CPD & -1.794 & -52.257 & Dry (Oct/2011) & Xingu & na & na & na & na & na & na & na & na & 0.52 & -28.33 \\
\hline XA 35 & RS - CPD & -2.039 & -52.192 & Dry (Oct/2011) & Xingu & na & na & na & na & na & na & na & na & 3.07 & -29.81 \\
\hline XA 36 & RS - CPD & -2.222 & -52.132 & Dry (Oct/2011) & Xingu & na & na & na & na & na & na & na & na & 3.24 & -29.84 \\
\hline XA 38 & RS - CPD & -2.466 & -52.016 & Dry (Oct/2011) & Xingu & na & na & na & na & na & na & na & na & 3.63 & -29.57 \\
\hline XA 49 & $\mathrm{RS}-\mathrm{OC}$ & -3.401 & -51.973 & Wet (May/2012) & Xingu & na & na & na & na & na & na & na & na & 0.64 & -28.59 \\
\hline XA 53 & $\mathrm{RS}-\mathrm{OC}$ & -2.625 & -51.969 & Wet (May/2012) & Xingu & na & na & na & na & na & na & na & na & 3.33 & -28.48 \\
\hline XA 55 & $\mathrm{RS}-\mathrm{OC}$ & -1.803 & -52.252 & Wet (May/2012) & Xingu & na & na & na & na & na & na & na & na & 1.74 & -29.53 \\
\hline XA 76 & RS - CPD & -2.462 & -52.097 & Wet (May/2012) & Xingu & na & na & na & na & na & na & na & na & 3.28 & -27.98 \\
\hline TAP 02A & $\mathrm{RS}-\mathrm{OC}$ & -2.472 & -54.995 & Dry (Sep/2011) & Tapajós & na & na & na & na & na & na & na & na & 2.99 & -31.04 \\
\hline TAP 02B & $\mathrm{RS}-\mathrm{OC}$ & -2.472 & -54.995 & Dry (Sep/2011) & Tapajós & na & na & na & na & na & na & na & na & 3.00 & -28.19 \\
\hline STM 12 & $\mathrm{RS}-\mathrm{OC}$ & -2.798 & -55.166 & Wet (May/2012) & Tapajós & na & na & na & na & na & na & na & na & 0.20 & na \\
\hline XC-02 & Core & -2.413 & -52.028 & Dry (Nov/2014) & Xingu & na & na & na & na & na & na & na & na & na & na \\
\hline $\mathrm{XC}-03$ & Core & -1.709 & -52.280 & Dry (Nov/2014) & Xingu & na & na & na & na & na & na & na & na & na & na \\
\hline $\mathrm{XC}-05$ & Core & -2.556 & -52.016 & Dry (Nov/2014) & Xingu & na & na & na & na & na & na & na & na & na & na \\
\hline
\end{tabular}




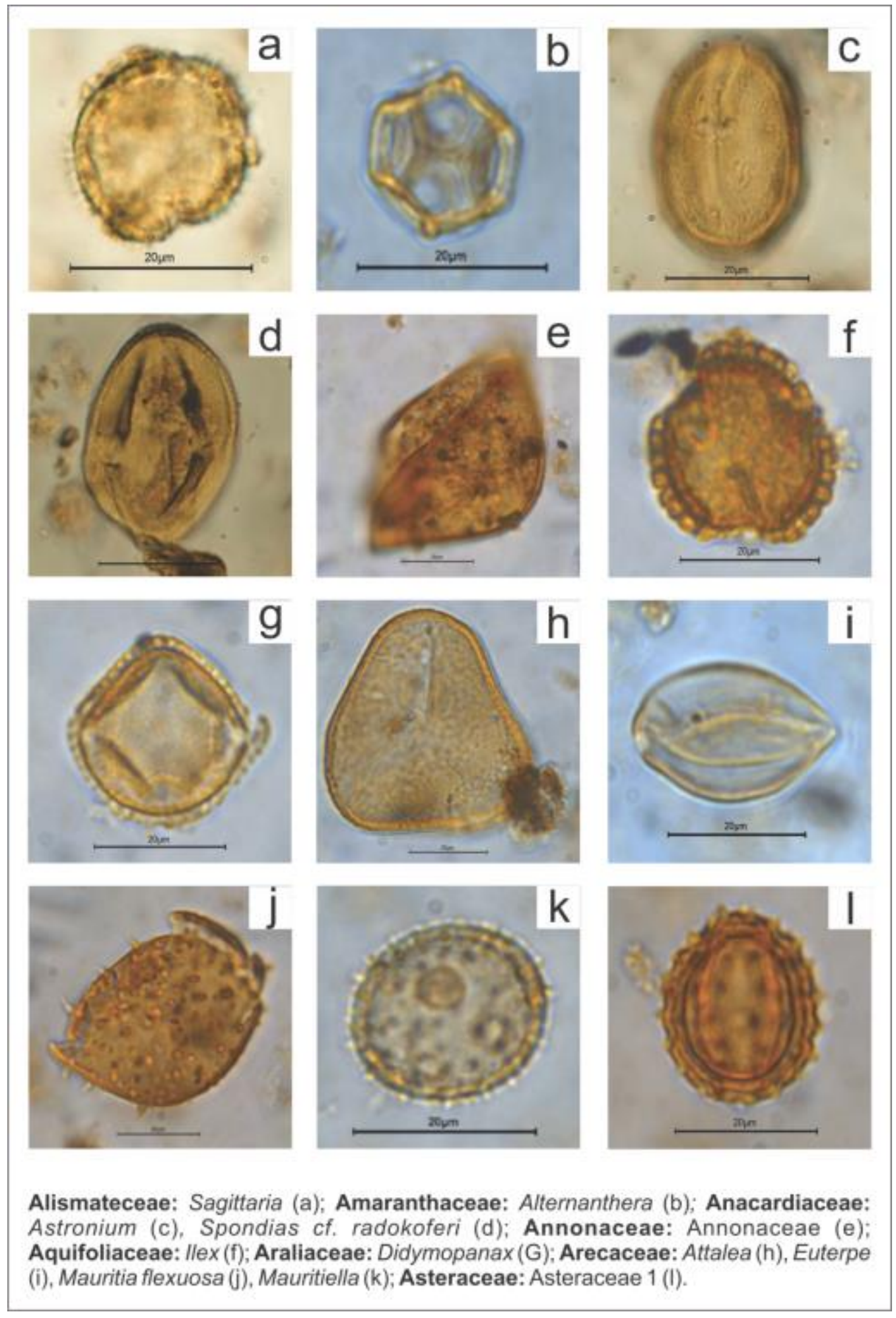

Figure S1 - Photomicrographs of selected pollen grains recovered from the sediment samples, Plate A. 


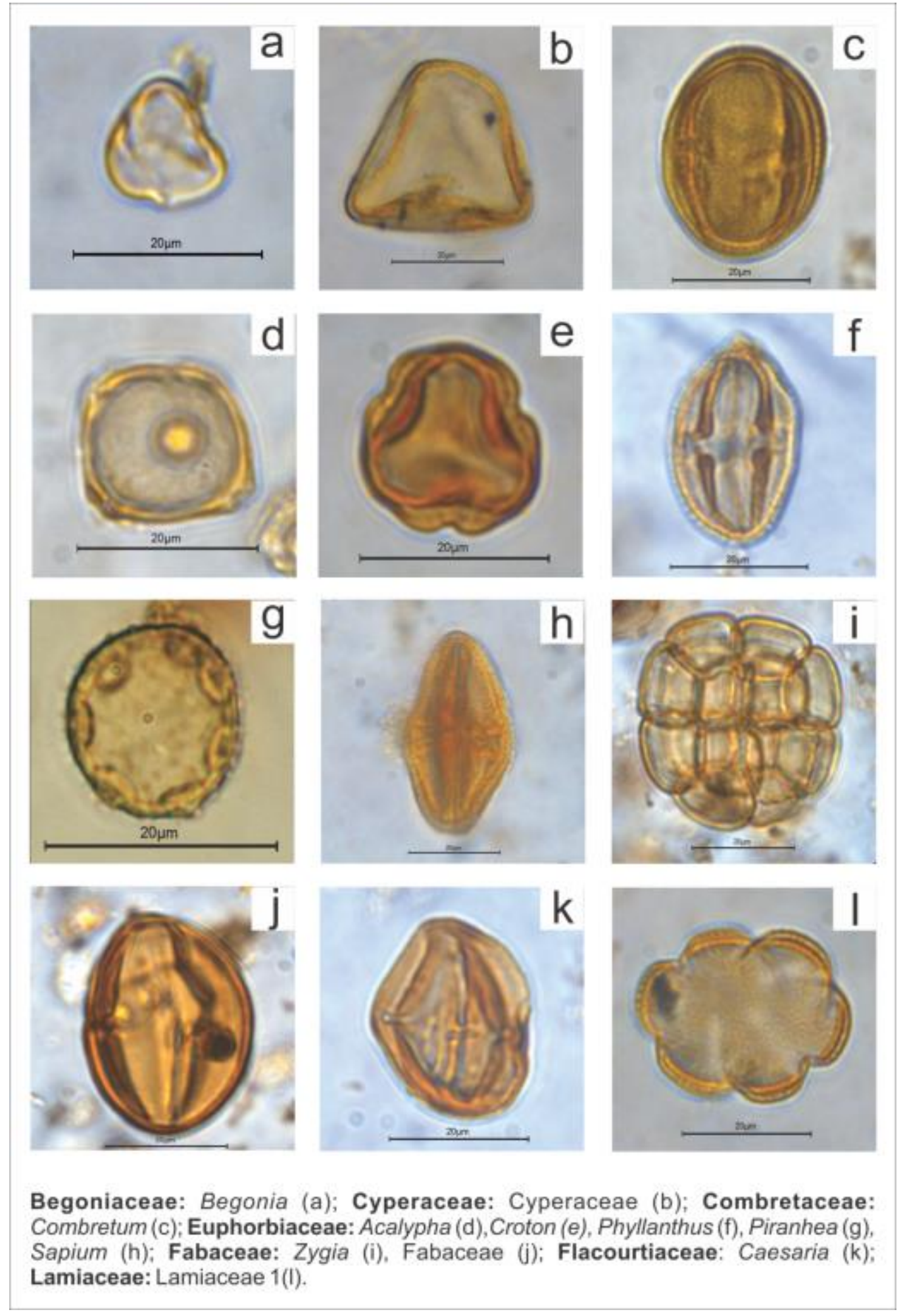

Figure S2 - Photomicrographs of selected pollen grains recovered from the sediment samples, Plate B. 


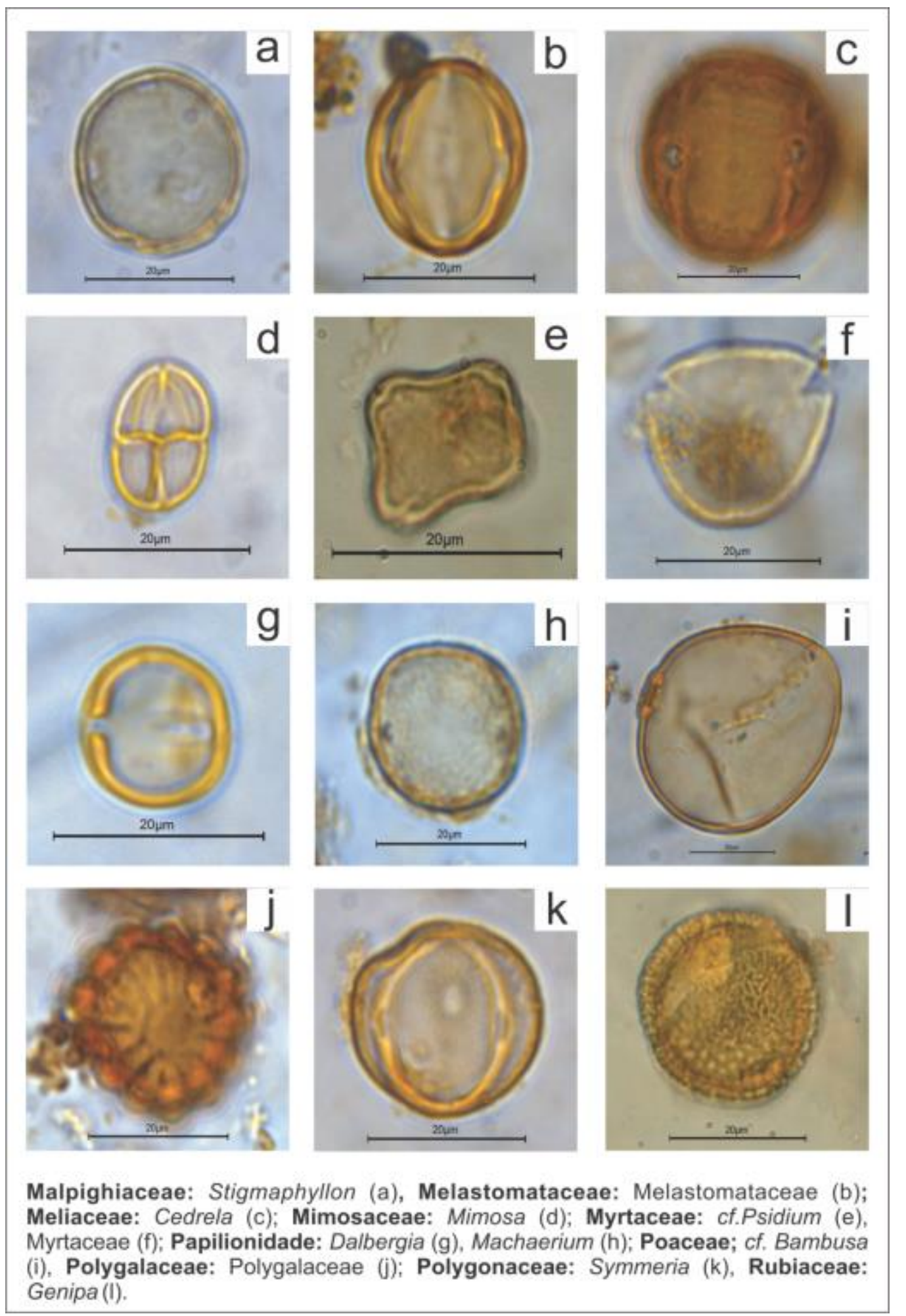

Figure S3 - Photomicrographs of selected pollen grains recovered from the sediment samples, Plate C. 


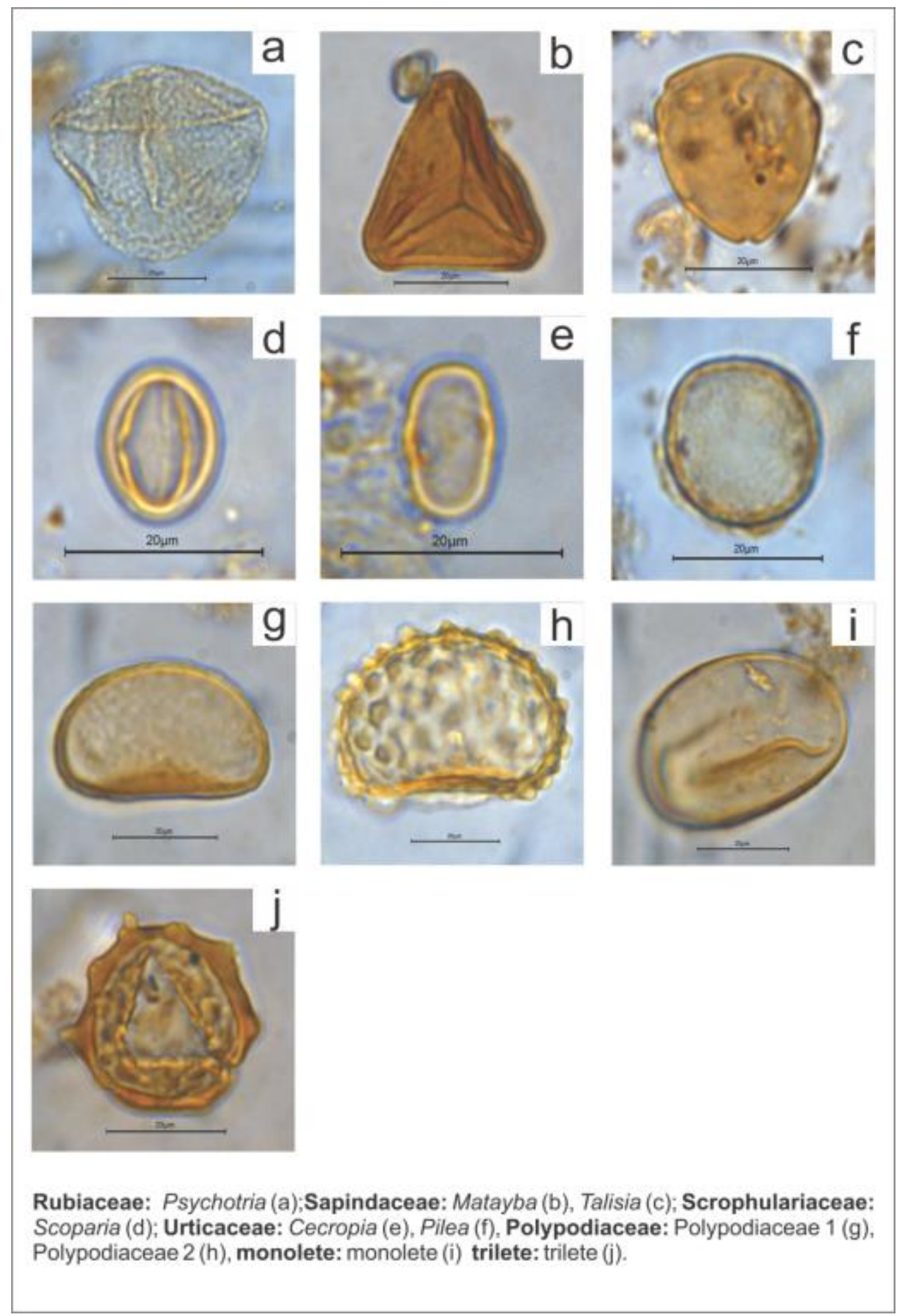

Figure S4 - Photomicrographs of selected pollen grains recovered from the sediment samples, Plate D. 


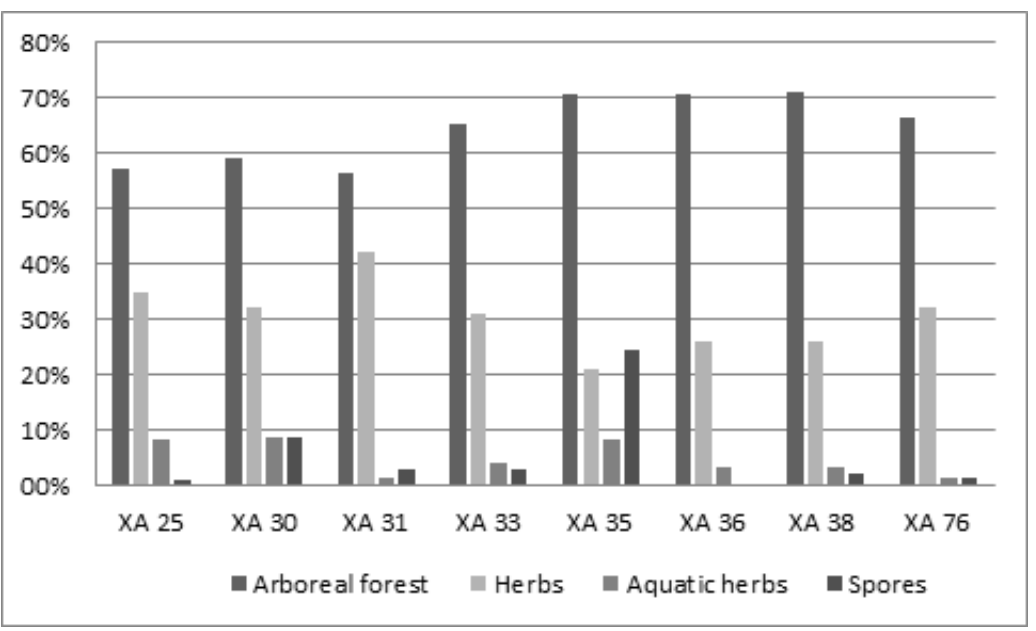

Figure S5 - Results of pollen count from riverbed sediments categorized by predominant vegetation type.

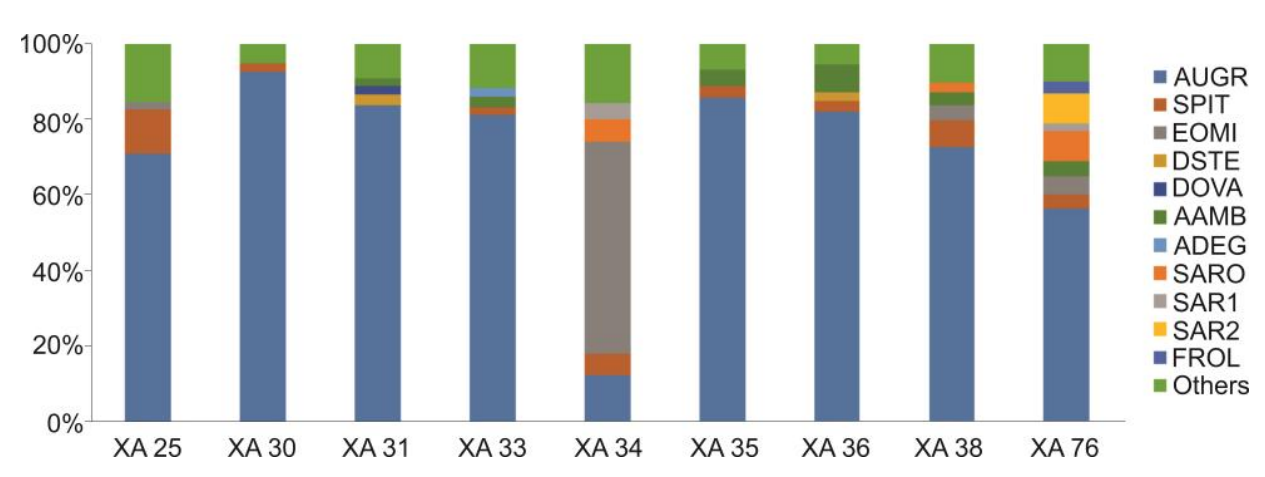

Figure S6 - Relative abundance of diatoms specimens (abundance $\geq 2 \%$ ), with joint contribution higher than $80 \%$ in the riverber sediments of the Xingu River. Aulacoseira granulate (AUGR); Staurosirella pinnata (SPIT); Eolimna minima (EOMI); Discostella stelligera (DSTE); Diploneis ovalis (DOVA); Aulacoseira ambígua (AAMB); Achnanthidium exiguum (ADEG); Staurosira cf. acutirostrata (SARO); Staurosirella sp.1 (SAR1); Staurosirella sp.2 (SAR2); Fragilaria rolandschmidtii (FROL). 
APPENDIX III - SUPPLEMENTARY MATERIAL: PRE- AND POST-FLOODING EMISSIONS OF METHANE AND CARBON DIOXIDE FROM THE BELO MONTE RESERVOIR AREA (XINGU RIVER, AMAZONIA) 
Supplementary Material for "Pre- and Post-flooding emissions of methane and carbon dioxide from the Belo Monte Reservoir area (Xingu River, Amazonia)"

In the following pages, supplementary data is provided in Table S1 and S2. 
Table S1 - Location, $\mathrm{FCH}_{4}, \mathrm{FCO}_{2}, \mathrm{pCH}_{4}, \mathrm{FdCH}_{4}$, and Ebull. data of individual samples from aquatic environments. n.a.=not available. UTM zone 22M.

\begin{tabular}{|c|c|c|c|c|c|c|c|c|c|}
\hline Ponto & UTM E & UTM S & Sampling date & $\begin{array}{c}\text { Depth } \\
\text { (m) }\end{array}$ & $\begin{array}{c}\mathrm{FdCH}_{4} \\
\left(\mathrm{~mol} \mathrm{~m}^{2} \mathbf{d}^{-1}\right) \\
\end{array}$ & $\begin{array}{c}\mathrm{FCH}_{4} \\
\left(\mathrm{mmol} \mathrm{m}^{2} \mathbf{d}^{-1}\right) \\
\end{array}$ & $\begin{array}{c}\text { Ebull. } \\
(\%)\end{array}$ & $\begin{array}{c}\text { pCH44 } \\
(\mu \mathrm{m})\end{array}$ & $\begin{array}{c}\mathrm{FCO}_{2} \\
\left(\mathrm{mmol} \mathrm{m}^{2} \mathbf{d}^{-1}\right) \\
\end{array}$ \\
\hline GEX2 & 368059 & 9644917 & Rainy Season (Apr/2016) & 2.3 & $7.4 \pm 1.66$ & 16.41 & 54.86 & $0.49 \pm 0.02$ & $93.49 \pm 59.97$ \\
\hline GEX3 & 372318 & 9644238 & Rainy Season (Apr/2016) & 13 & $0.45 \pm 0.04$ & 0.45 & 0 & $0.13 \pm 0$ & $125.62 \pm 39.9$ \\
\hline GEX4 & 374110 & 9645075 & Rainy Season (Apr/2016) & 0.6 & $2.9 \pm$ n.a. & 6.91 & 58.04 & $0.8 \pm 0.04$ & $34.55 \pm 0.28$ \\
\hline GEX5 & 389860 & 9630809 & Rainy Season (Apr/2016) & 4.4 & $121.67 \pm 3.3$ & 121.67 & 0 & $0.79 \pm 0.04$ & $105.93 \pm 57.86$ \\
\hline GEX6 & 392459 & 9622844 & Rainy Season (Apr/2016) & 6.1 & $2.53 \pm$ n.a. & 7.69 & 67.14 & $0.5 \pm 0.03$ & $99.78 \pm 27.12$ \\
\hline GEX7 & 395866 & 9621475 & Rainy Season (Apr/2016) & 9 & $1.01 \pm$ n.a. & 4.52 & 77.67 & $0.34 \pm 0.02$ & $64.31 \pm 7.25$ \\
\hline GEX8 & 391336 & 9625734 & Rainy Season (Apr/2016) & 21 & $0.31 \pm 0.02$ & 0.31 & 0 & $0.26 \pm 0.02$ & $91.15 \pm 20.9$ \\
\hline GEX9 & 393945 & 9619544 & Rainy Season (Apr/2016) & 6 & $0.88 \pm 0.03$ & 1.06 & 16.3 & $0.21 \pm 0.03$ & $195.83 \pm 95.58$ \\
\hline GEX10 & 413372 & 9655662 & Rainy Season (Apr/2016) & 10 & $0.26 \pm 0.02$ & 0.31 & 15.69 & $0.07 \pm 0.02$ & $99.58 \pm 58.35$ \\
\hline GEX11 & 398422 & 9678207 & Rainy Season (Apr/2016) & 10 & $0.91 \pm 0.1$ & 0.91 & 0 & $0.08 \pm 0$ & $137.51 \pm 106.38$ \\
\hline GEX13 & 372380 & 9644185 & Rainy Season (May/2017) & 15 & $0.98 \pm 0.28$ & 1.19 & 17.9 & $0.17 \pm 0$ & $137.13 \pm 14.85$ \\
\hline GEX14 & 374323 & 9645250 & Rainy Season (May/2017) & 1 & $1.1 \pm 0.23$ & 1.1 & 0 & $1.16 \pm 0.04$ & $39.77 \pm 15.56$ \\
\hline GEX16 & 389852 & 9630812 & Rainy Season (May/2017) & 6.2 & $0.41 \pm$ n.a. & 11.07 & 96.26 & $0.6 \pm 0.09$ & $70.27 \pm 26.67$ \\
\hline GEX18 & 359046 & 9613425 & Rainy Season (May/2017) & 13 & $1.19 \pm 0.13$ & 1.19 & 0 & $0.2 \pm 0.02$ & $119.94 \pm 42.84$ \\
\hline GEX19 & 365011 & 9623420 & Rainy Season (May/2017) & 9 & $0.34 \pm$ n.a. & 0.75 & 54.37 & $0.19 \pm 0.01$ & $65.44 \pm 10.24$ \\
\hline GEX20 & 368033 & 9644897 & Rainy Season (May/2017) & 4 & $19.77 \pm 6.16$ & 56.98 & 65.3 & $0.58 \pm 0.12$ & $64.48 \pm 36.83$ \\
\hline GEX21 & 393953 & 9619439 & Rainy Season (May/2017) & 2.6 & $3 \pm 0.28$ & 3 & 0 & $0.41 \pm 0.01$ & $246.96 \pm 103.78$ \\
\hline GEX25 & 392419 & 9622845 & Rainy Season (May/2017) & 6 & $1.6 \pm 0.28$ & 6.11 & 73.78 & $0.5 \pm 0.02$ & $32.45 \pm 1.7$ \\
\hline GEX26 & 395866 & 9621475 & Rainy Season (May/2017) & 11 & $0.21 \pm$ n.a. & 3.13 & 93.13 & $0.48 \pm 0.02$ & $52.87 \pm 24.14$ \\
\hline GEX28 & 412684 & 9651294 & Rainy Season (May/2017) & 55 & $0.38 \pm 0.04$ & 1.05 & 63.91 & $0.12 \pm 0$ & $152.06 \pm 53.26$ \\
\hline GEX29 & 414434 & 9640131 & Rainy Season (May/2017) & 6.5 & $0.54 \pm 0.02$ & 17.44 & 96.93 & $0.3 \pm 0.01$ & $45.88 \pm 15.99$ \\
\hline GEX31 & 409369 & 9636239 & Rainy Season (May/2017) & 22 & $4.13 \pm$ n.a. & 13.96 & 70.39 & $0.39 \pm 0.02$ & $82.48 \pm 52.68$ \\
\hline GEX33 & 391225 & 9625673 & Rainy Season (May/2017) & 15 & $3.42 \pm 0.74$ & 3.42 & 0 & $0.38 \pm 0.04$ & $120.78 \pm 13.13$ \\
\hline GEX34 & 390649 & 9626161 & Rainy Season (May/2017) & 7.9 & $9.95 \pm 1.95$ & 21.71 & 54.17 & $0.71 \pm 0.02$ & $29.22 \pm 7.29$ \\
\hline GEX35 & 384048 & 9628924 & Rainy Season (May/2017) & 5.5 & $1.22 \pm$ n.a. & 34.33 & 96.44 & $0.42 \pm 0.01$ & $128.98 \pm 45.91$ \\
\hline GEX42 & 398388 & 9678279 & Rainy Season (May/2017) & 8 & $0.36 \pm 0.02$ & 0.36 & 0 & $0.07 \pm 0$ & $225.53 \pm 52.55$ \\
\hline GEX43 & 395948 & 9621599 & Dry Season (Sep/2017) & 11 & $1.1 \pm 0.28$ & 1.1 & 0 & $0.3 \pm 0$ & $41.3 \pm 7.34$ \\
\hline
\end{tabular}




\begin{tabular}{|c|c|c|c|c|c|c|c|c|c|}
\hline Ponto & UTM E & UTM S & Sampling date & $\begin{array}{c}\text { Depth } \\
\text { (m) }\end{array}$ & $\begin{array}{c}\mathrm{FdCH}_{4} \\
\left(\mathrm{~mol} \mathrm{~m}^{2} \mathbf{d}^{-1}\right)\end{array}$ & $\begin{array}{c}\mathrm{FCH}_{4} \\
\left(\mathrm{mmol} \mathrm{m}^{2} \mathbf{d}^{-1}\right)\end{array}$ & $\begin{array}{c}\text { Ebull. } \\
(\%)\end{array}$ & $\begin{array}{c}\text { pCH4 } \\
(\mu \mathrm{m})\end{array}$ & $\begin{array}{c}\mathrm{FCO}_{2} \\
\left(\mathrm{mmol} \mathrm{m}^{2} \mathbf{d}^{-1}\right)\end{array}$ \\
\hline GEX46 & 391300 & 9625310 & Dry Season (Sep/2017) & 15 & $0.46 \pm$ n.a. & 0.86 & 46.82 & $0.19 \pm 0.02$ & $35.98 \pm 8.37$ \\
\hline GEX48 & 389850 & 9630814 & Dry Season (Sep/2017) & 5 & $1.65 \pm 0.42$ & 23.36 & 92.95 & $0.53 \pm 0.13$ & $29.95 \pm 5.99$ \\
\hline GEX50 & 384036 & 9628949 & Dry Season $(\mathrm{Sep} / 2017)$ & 6 & $53.25 \pm 6.95$ & 58.17 & 8.46 & $0.79 \pm 0.17$ & $50.69 \pm$ n.a. \\
\hline GEX54 & 359060 & 9613277 & Dry Season $(\mathrm{Sep} / 2017)$ & 11 & $0.13 \pm$ n.a. & 0.47 & 71.7 & $0.06 \pm 0$ & $89.12 \pm$ n.a. \\
\hline GEX55 & 365120 & 9623330 & Dry Season (Sep/2017) & 11 & $0.41 \pm 0.05$ & 0.41 & 0 & $0.08 \pm 0$ & $99.82 \pm 64.24$ \\
\hline GEX57 & 409530 & 9635635 & Dry Season (Oct/2017) & 27 & $0.31 \pm$ n.a. & 0.85 & 63.81 & $0.17 \pm 0.03$ & $450.71 \pm 193.69$ \\
\hline GEX59 & 414728 & 9639596 & Dry Season (Oct/2017) & 30 & $0.74 \pm 0.32$ & 1.94 & 61.89 & $0.13 \pm 0$ & $409.23 \pm 255.7$ \\
\hline GEX60 & 412918 & 9651721 & Dry Season (Oct/2017) & 55 & $0.87 \pm 0.07$ & 2.78 & 68.67 & $0.06 \pm 0$ & $1037.42 \pm 277.8$ \\
\hline GEX61 & 390684 & 9626145 & Dry Season (Oct/2017) & 6 & $18.4 \pm 2.72$ & 33.05 & 44.31 & $0.17 \pm 0$ & $38.89 \pm 31.23$ \\
\hline GEX62 & 392416 & 9622837 & Dry Season (Oct/2017) & 5 & $4.34 \pm 0.17$ & 10.82 & 59.85 & $1.28 \pm 0.1$ & $63.58 \pm$ n.a. \\
\hline GEX63 & 394156 & 9620035 & Dry Season (Oct/2017) & 15 & $0.55 \pm 0.06$ & 0.55 & 0 & $0.14 \pm 0$ & $64.5 \pm 2.73$ \\
\hline GEX66 & 372221 & 9643897 & Dry Season (Oct/2017) & 15 & $5.02 \pm 0.53$ & 5.02 & 0 & $0.29 \pm 0$ & $84.4 \pm 38.61$ \\
\hline GEX68 & 368033 & 9644897 & Dry Season (Oct/2017) & 3 & $8.13 \pm 2.93$ & 24.21 & 66.44 & $1.25 \pm 0.08$ & $69.27 \pm 18.81$ \\
\hline GEX69 & 398096 & 9678362 & Dry Season (Oct/2017) & 9 & $0.52 \pm 0.14$ & 0.55 & 4.79 & $0.11 \pm 0.01$ & $-45.1 \pm$ n.a. \\
\hline GEX70 & 413306 & 9655553 & Dry Season (Oct/2017) & 7.5 & $0.56 \pm 0.03$ & 0.56 & 0 & $0.17 \pm 0.01$ & $65.18 \pm$ n.a. \\
\hline Altamira & 372318 & 9644238 & Dry Season (Dec/2014) & 14 & $0.53 \pm 0.05$ & 2.12 & 74.85 & $0.26 \pm 0.04$ & $-10.21 \pm 1.14$ \\
\hline Barragem & 391664 & 9625245 & Dry Season (Dec/2014) & 6.5 & $0.32 \pm 0.06$ & 0.39 & 17.42 & $0.2 \pm 0.01$ & $-19.49 \pm 6.78$ \\
\hline Vitoria & 398488 & 9678043 & Dry Season (Nov/2014) & 7 & $1.43 \pm 0.16$ & 1.43 & 0 & $0.21 \pm 0.01$ & $17.84 \pm 4.65$ \\
\hline XA-81 & 391337 & 9625222 & Dry Season (Nov/2012) & 6.6 & $0.52 \pm 0.09$ & 0.52 & 0 & $0.13 \pm 0.01$ & $4.68 \pm 2.94$ \\
\hline XA-82 & 372399 & 9644165 & Dry Season (Nov/2012) & 7.4 & $1.28 \pm 0.1$ & 3.85 & 66.8 & $0.24 \pm 0.02$ & $-31.89 \pm 12.52$ \\
\hline XA-83 & 398488 & 9678043 & Dry Season (Nov/2012) & 7 & $1.07 \pm 0.24$ & 5.04 & 78.73 & $0.15 \pm 0.01$ & $-19.01 \pm 2.86$ \\
\hline XA-39 & 373497 & 9643872 & Rainy Season (May/2012) & 6.8 & $2.48 \pm 0.3$ & 2.62 & 5.22 & $0.04 \pm 0$ & $177.61 \pm 30.06$ \\
\hline XA-49 & 391949 & 9624083 & Rainy Season (May/2012) & 14 & $0.79 \pm 0.07$ & 0.79 & 0 & $0.05 \pm 0$ & $55.87 \pm 24.18$ \\
\hline XA-80 & 398539 & 9677973 & Rainy Season (May/2012) & 10.9 & $0.26 \pm 0.02$ & 0.26 & 0 & $0.03 \pm 0$ & $19.04 \pm 5.68$ \\
\hline
\end{tabular}


Table S2 - Location, vegetation cover, $\mathrm{FCH}_{4}$ and $\mathrm{FCO}_{2}$ of individual chambers and sites from soils. n.a.=not available. UTM zone 22M.

\begin{tabular}{|c|c|c|c|c|c|c|c|}
\hline Sample & $\begin{array}{c}\text { Sampling } \\
\text { date }\end{array}$ & UTM E & UTM S & $\begin{array}{c}\text { Vegetation } \\
\text { cover }\end{array}$ & Chamber & $\begin{array}{c}\mathrm{FCH}_{4} \\
\left(\mathrm{mmol} \mathrm{m}^{2} \mathbf{d}^{-1}\right) \\
\end{array}$ & $\begin{array}{c}\mathrm{FCO}_{2} \\
\left(\mathrm{mmol} \mathrm{m}^{2} \mathrm{~d}-1\right) \\
\end{array}$ \\
\hline \multirow[t]{3}{*}{ GEX12 } & Rainy Season & 367420 & 9642928 & Forest* & GEX12A & n.a. & 856.0172 \\
\hline & (May/2017) & & & & GEX12B & 1.235239 & 1415.565 \\
\hline & & & & & GEX12C & 0.096305 & 152.0982 \\
\hline \multirow[t]{2}{*}{ GEX15 } & Rainy Season & 374420 & 9645337 & Pasture & GEX15A & 1.261478 & n.a. \\
\hline & (May/2017) & & & & GEX15C & 0.735694 & n.a. \\
\hline \multirow[t]{3}{*}{ GEX17 } & Rainy Season & 389867 & 9630830 & Forest & GEX17A & n.a. & 163.2713 \\
\hline & (May/2017) & & & & GEX17B & n.a. & 707.725 \\
\hline & & & & & GEX17C & n.a. & 363.5074 \\
\hline \multirow[t]{2}{*}{ GEX27 } & Rainy Season & 392440 & 9622965 & Pasture & GEX27A & -0.03489 & n.a. \\
\hline & (May/2017) & & & & GEX27B & 0.227498 & n.a. \\
\hline \multirow[t]{3}{*}{ GEX30 } & Rainy Season & 414309 & 9640093 & Forest & GEX30A & -0.05363 & 218.1564 \\
\hline & (May/2017) & & & & GEX30B & & 207.4014 \\
\hline & & & & & GEX30C & -0.03143 & 267.7504 \\
\hline \multirow[t]{3}{*}{ GEX32 } & Rainy Season & 408521 & 9636104 & Pasture & GEX32A & 0.08506 & 399.3766 \\
\hline & (May/2017) & & & & GEX32B & 0.08852 & 367.5441 \\
\hline & & & & & GEX32C & 0.136672 & 346.7262 \\
\hline \multirow[t]{3}{*}{ GEX36 } & Rainy Season & 383692 & 9629200 & Forest & GEX36A & -0.03604 & 199.1549 \\
\hline & (May/2017) & & & & GEX36B & 0.276516 & 346.236 \\
\hline & & & & & GEX36C & -0.09602 & 335.7693 \\
\hline \multirow[t]{4}{*}{ GEX44 } & Dry Season & 392440 & 9622965 & Pasture & GEX44A & 0.04435 & 195.4234 \\
\hline & $(\mathrm{Sep} / 2017)$ & & & & GEX44B & 0.090873 & 292.5695 \\
\hline & & & & & GEX44C & -0.10464 & 208.715 \\
\hline & & & & & GEX44D & -0.06348 & 245.7292 \\
\hline \multirow[t]{4}{*}{ GEX47 } & Dry Season & 389867 & 9630830 & Forest & GEX47A & n.a. & 90.00067 \\
\hline & $(\operatorname{Sep} / 2017)$ & & & & GEX47B & -0.78061 & 153.197 \\
\hline & & & & & GEX47C & 0.727278 & 104.8336 \\
\hline & & & & & GEX47D & -0.38494 & 157.7879 \\
\hline \multirow[t]{4}{*}{ GEX49 } & Dry Season & 383692 & 9629200 & Forest & GEX49A & -0.1 & 158.6877 \\
\hline & $(\operatorname{Sep} / 2017)$ & & & & GEX49B & 0.195081 & 159.8135 \\
\hline & & & & & GEX49C & 0.214792 & 88.99714 \\
\hline & & & & & GEX49D & n.a. & 235.1205 \\
\hline \multirow[t]{4}{*}{ GEX56 } & Dry Season & 408521 & 9636104 & Pasture & GEX56A & -0.01442 & 245.0969 \\
\hline & $(\mathrm{Oct} / 2017)$ & & & & GEX56B & -0.0865 & 257.1261 \\
\hline & & & & & GEX56C & -0.02595 & 178.3816 \\
\hline & & & & & GEX56D & -0.04959 & 157.2294 \\
\hline \multirow[t]{4}{*}{ GEX58 } & Dry Season & 414309 & 9640093 & Forest & GEX58B & -0.07727 & 154.2264 \\
\hline & $(\mathrm{Oct} / 2017)$ & & & & GEX58B & n.a. & 92.56536 \\
\hline & & & & & GEX58C & n.a. & 177.3286 \\
\hline & & & & & GEX58D & -0.0372 & 133.2317 \\
\hline \multirow[t]{3}{*}{ GEX64 } & Dry Season & 374420 & 9645333 & Pasture & GEX64A & n.a. & 371.5497 \\
\hline & (Oct/2017) & & & & GEX64B & -0.13848 & 61.43868 \\
\hline & & & & & GEX64C & -0.10678 & 144.4973 \\
\hline GEX65 & Dry Season & 374423 & 9645287 & Pasture & GEX65A & -0.02934 & 379.5709 \\
\hline
\end{tabular}




\begin{tabular}{|c|c|c|c|c|c|c|c|}
\hline Sample & $\begin{array}{c}\text { Sampling } \\
\text { date }\end{array}$ & UTM E & UTM S & $\begin{array}{c}\text { Vegetation } \\
\text { cover }\end{array}$ & Chamber & $\begin{array}{c}\mathrm{FCH}_{4} \\
\left(\mathrm{mmol} \mathrm{m}^{2} \mathbf{d}^{-1}\right) \\
\end{array}$ & 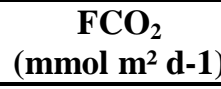 \\
\hline \multirow{6}{*}{ GEX67 } & $(\mathrm{Oct} / 2017)$ & & & & GEX65B & n.a. & 312.2532 \\
\hline & & & & & GEX65C & -0.04511 & 220.7242 \\
\hline & & & & & GEX65D & -0.04292 & 388.3719 \\
\hline & Dry Season & 367349 & 9642900 & Forest* & GEX67A & -0.14365 & 141.944 \\
\hline & $(\mathrm{Oct} / 2017)$ & & & & GEX67C & -0.23037 & 411.2066 \\
\hline & & & & & GEX67D & -0.11825 & 469.8041 \\
\hline
\end{tabular}

